University of Rhode Island

DigitalCommons@URI

Open Access Master's Theses

1996

\title{
A Location Analysis of Tenant-Based Rental Assistance in the Capitol Region Planning Area, Hartford, Connecticut
}

Linda Osten

University of Rhode Island

Follow this and additional works at: https://digitalcommons.uri.edu/theses

\section{Recommended Citation}

Osten, Linda, "A Location Analysis of Tenant-Based Rental Assistance in the Capitol Region Planning Area, Hartford, Connecticut" (1996). Open Access Master's Theses. Paper 692.

https://digitalcommons.uri.edu/theses/692

This Thesis is brought to you for free and open access by DigitalCommons@URI. It has been accepted for inclusion in Open Access Master's Theses by an authorized administrator of DigitalCommons@URI. For more information, please contact digitalcommons-group@uri.edu. 
A LOCATION ANALYSIS OF TENANT-BASED RENTAL ASSISTANCE IN THE CAPITOL REGION PLANNING AREA,HARTFORD, CONNECTICUT

\author{
BY \\ LINDA OSTEN
}

\begin{abstract}
A RESEARCH PROJECT SUBMITTED IN PARTIAL FULFILLMENT OF THE REQUIREMENTS FOR THE DEGREE OF MASTER OF COMMUNITY PLANNING
\end{abstract}

UNIVERSITY OF RHODE ISLAND 1996 
A LOCATION ANALYSIS OF TENANT-BASED RENTAL ASSISTANCE IN THE CAPITOL REGION PLANNING AREA, HARTFORD, CONNECTICUT

BY

LINDA OSTEN

Approved:

Major Professor

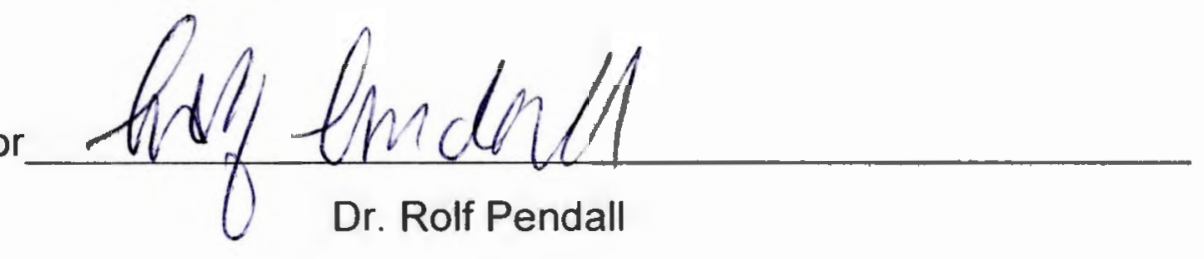

Acknowledged:

Director

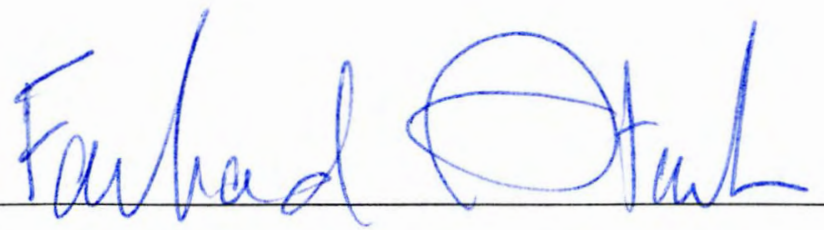

Dr. Farhad Atash 


\section{ACKNOWLEDGEMENTS}

This study owes its genesis to my experience interning at the Capitol Region Council of Governments in Hartford, Connecticut during the summer of 1995. It was there that I was introduced to the Capitol Region Fair Housing Compact On Affordable Housing. As I prepared the Compact's annual report and worked with town and regional planners, I learned of the regional and local concerns regarding affordable housing in general and tenant-based rental assistance in particular. This experience, coupled with timely debates in Washington over changes in Section 8 policy led to my choice of this topic. It has proved to be a rewarding and complex topic.

I would like to thank Professor Rolf Pendall for his insight, encouragement, and teachings during the development, and now completion, of this project. From commas to chi-square, he guided my progress with respect and support. My educational foundation is far stronger for his instructions and assistance.

My thanks to Professor Marcia Marker Feld as well for her readings and comments, from D.C. and back. She first introduced me to social indicators and continues to give me hope that planning is a tool for achieving equity from neighborhoods to nations.

Finally, I thank Mary Ellen Kowalewski, Director of Community Development at the Capitol Region Council of Governments, for her patience and professional guidance. Her contacts made this project possible, her encouragement made it attainable. 
CHAPTER ONE: INTRODUCTION

STATEMENT OF THE PROBLEM

SIGNIFICANCE OF THE STUDY

OBJECTIVES AND CHAPTER OUTLINE

\section{CHAPTER TWO: THE STUDY ENVIRONMENT}

CAPITOL REGION FAIR HOUSING COMPACT

The Compact process and agreements

Current status of the Compact

CONTEXT AND BACKGROUND

Regional profile

Municipal profiles

HOUSING MOBILITY AND PORTABILITY PROGRAMS

What is housing mobility?

Housing mobility debates

20

Capitol Region programs

CHAPTER THREE: RESEARCH DESIGN AND METHODOLOGY

INTRODUCTION TO ANALYSIS

RESEARCH QUESTIONS

SUMMARY OF METHODS

Modeling

Locating tenant-based assistance

Social indicators

LIMITATIONS

Use of social indicators

Census data notations

Other considerations

CHAPTER FOUR: SOCIAL INDICATOR ASSESSMENT

SOCIAL INDICATOR REVIEW

Background

Definition and description

Concerns

SETTING THE STAGE

Outcomes of the Hartford Special Mobility program

ANALYSIS

Poverty tracts

Neighborhood distress indicators

Rental desirability indicators 
CHAPTER FIVE: LOCATION ANALYSIS 85

PROGRAM COMPARISON 85

THE CONCENTRATION METHODOLOGY _ 93

RACIAL CONCENTRATION 98

The regional level 98

The town level 100

ECONOMIC CONCENTRATION 111

The regional level

The town level

SUMMARY

CHAPTER SIX: CONCLUSIONS

REGIONAL RESULTS 115

TOWN RESULTS

RECOMMENDATIONS

AREAS FOR FUTURE STUDY

RESEARCH LIMITATIONS AND ADVANCES

APPENDIX 1

APPENDIX 2

APPENDIX 3 136

APPENDIX 4 144

APPENDIX 5 148

APPENDIX 6 152

WORKS CITED 156 


\section{Directory of Tables}

Table 1 Capitol Region Compact Goals 8

Table 2 Population, Area, and Density by Town 14

Table 3 Range of Municipal Median Sale Prices 16

Table 41990 Capitol Region Population Percentages by Race 17

Table 5 Rank by Socio-Economic Status 19

Table 6 1995/1996 Regional Tenant Assistance 39

Table 7 Capitol Region Portability 57

Table 8 Hartford Special Mobility Program: 1992 and 1996 60

Table 9 Regional Chi-Square Results: Racial Concentration 99

Table 10 Town Cross-Tabulation Results: HUD Racial Concentration 100

Table 11 Regional Chi-Square Results: Economic Concentration 111 


\section{Directory of Figures}

Figure 1 Capitol Planning Region 15

Figure 2 Census Tract Boundaries 29

Figure 3 Poverty Tracts 64

Figure 4 Distressed Census Tracts 65

Figure 5 Census Tract Rental Characteristics 72

Figure 6 Enfield Rental Characteristics 73

Figure 7 Windsor Rental Characteristics 75

Figure 8 Vernon Rental Characteristics 76

Figure 9 East Hartford Rental Characteristics 78

Figure 10 Manchester Rental Characteristics 79

Figure 11 West Hartford Rental Characteristics 80

Figure 12 Portable Programs 86

Figure 13 Town Programs 87

Figure 14 Certificate Density 90

Figure 15 Household Density 91

Figure 16 State Programs 92

Figure 17 East Hartford Tenant-Based Rental Assistance 102

Figure 18 Enfield Tenant-Based Rental Assistance 105

Figure 19 Manchester Tenant-Based Rental Assistance 106

Figure 20 West Hartford Tenant-Based Rental Assistance 108 


\section{CHAPTER ONE: INTRODUCTION}

\section{Statement of the problem}

Connecticut ranks ninth among all states in housing segregation and first in average city/suburb income gap. Hartford, the State's capital and the fourth poorest city in the nation, lies in the center of the state with the highest income per capita (National Public Radio Moming Edition, October 9, 1996; U.S. Bureau of the Census 1995: Table 714). In 1990, 8.5 percent of households in Connecticut and 7.7 percent in the Capitol Region lived below the federal poverty level; 26.0 percent of Hartford households were below the poverty line (CT Department of Economic Development; Hartford Planning Department). In addition, before the economic downturn of the 1990s, Connecticut had the highest housing costs east of California (U.S. Department of Housing and Urban Development 1995). In response to these statistics and advocates' calls for more affordable housing, the Connecticut General Assembly passed several State laws in the late 1980s aimed at promoting the production of affordable housing.

One of these legislative actions was a statute that provided for a pilot program in which two of the State's planning regions were selected to develop "through the process of a negotiated investment strategy...a regional fair housing compact to provide increased housing for low-and moderate-income families" (Connecticut Public Act 88-334, 1988). The area including the capital city of 
Hartford was one of the two regions selected to participate in the program; the organizing agency was the Capitol Region Council of Governments (CRCOG).

The outcome of these negotiations was the Capitol Region Fair Housing Compact On Affordable Housing (CRFHC or Compact), agreed to by 26 of the 29 municipalities; the Compact ran from May 1, 1990 to April 31, 1995.

This study will undertake an assessment of a program which is a key component of the Compact, tenant-based Section 8 units. This study examines the neighborhood impacts of the Capitol Region tenant-based Section 8 program in general and the Hartford Special Mobility program in particular. Tenant-based Section 8 programs provide opportunities to increase affordable housing choices. It is not without controversy, however. The location and concentration of Section 8 units is an area ripe for study. Relatively little is known about the regional distribution of these units. And the combination of a study which examines the regional and local interrelationships, as this study does, is unique in the literature.

\section{Significance of the study}

The CRCOG Housing Committee cites several reasons to support a regional affordable housing policy (1995).

1. The original goals targeted only 25 percent of local affordable housing shortfalls; even towns that met goal still have great need.

2. Housing costs are a primary factor which drive an area's cost of living. 
3. Labor markets are regional; approximately 89.3 percent of the region's working residents work in the region.

4. Future state and federal housing funds will likely be very limited; the burden will fall on municipalities.

5. An economically diverse work force requires a range of housing options.

Despite the above, negotiating a renewed Compact is likely to encounter formidable political difficulties. Not the least controversial is the response to the Section 8 program, particularly its portability aspects. The Mayor of East Hartford is already on record noting his apprehension with the number of voucher holders moving from Hartford to East Hartford (Swift and Dempsey, 1995).

In order to address the concerns of policy makers, CRCOG, as the organizing agency of the Compact, requires a more complete analysis of the tenant-based rental assistance program. It is necessary to know to which towns and neighborhoods recipients live and are moving, and whether there is a concentration of certificate households in particular neighborhoods. Policy makers also need to agree on a definition for concentration and whether findings of concentration call for a response. Furthermore, if the study finds concentration, decision-makers need to know the options in their community to address that concentration should they decide to fashion a response. The up-todate information provided by this study can benefit policy-makers by creating an opportunity to: 1) devise policy changes to mitigate problems resulting from the tenant-based rental assistance program and 2) revise inaccurate perceptions 
about portability program impacts. Therefore, this assessment of rental subsidy concentration and accompanying neighborhood descriptions will assist decisionmakers in the next round of affordable housing negotiations. That is the purpose of this study.

\section{Objectives and chapter outline}

This study has three major, interrelated objectives: 1) to identify and map the destination of tenant-based Section 8 units by Census tract; 2) to describe through sets of indicators areas of rental desirability and areas of distress; and 3) to suggest potential policy changes to address the results of the above. The outline of chapters is as follows:

Chapter 1: Introduction

Chapter 2: Study Environment

Chapter 3: Research Design

Chapter 4: Social Indicator Assessment

Chapter 5: Destination Analysis

Chapter 6: Conclusion 


\section{CHAPTER TWO: THE STUDY ENVIRONMENT}

This chapter covers the history and current status of the Capitol Region Fair Housing Compact On Affordable Housing, provides demographic and geographic context for the region, and describes the tenant-based housing assistance programs available throughout the region.

\section{Capitol region fair housing compact}

\section{The Compact process and agreements}

The Capitol Planning Region includes one city and 28 towns. ${ }^{1}$ Each of the municipalities signed an agreement to participate in the formation of an affordable housing plan and entered into negotiating sessions that lasted throughout the first half of 1989 . These sessions included one representative from each of the 29 Capitol Region municipalities, representatives from the State Department of Housing, the State Office of Policy and Management, and the Capitol Region Council of Governments, as well as professional mediators from Endispute, Incorporated.

The participants had to resolve many issues during the negotiation process, including the definition of affordable housing; the formula for determining targets; environmental and land use constraints; maintaining community character; allocating responsibility across the region; possible

\footnotetext{
1 The Capitol Region includes: Andover, Avon, Bloomfield, Bolton, Canton, East Granby, East Hartford, East Windsor, Ellington, Enfield, Farmington, Glastonbury, Granby, Hartford, Hebron,
} 
solutions to housing shortfalls; respecting local autonomy; funding for new initiatives; and the statutory deadline (Susskind and Podziba, 1990: 6,8). Suburban representatives expressed early concern that they were being asked to "solve Hartford's problems." The Hartford representative's reply: "If each community would take care of its own residents, Hartford's burden would be eased" (Susskind and Podziba, 1990: 7). The Hartford representative directed his statement at the lack of affordable housing available in the suburban communities. If adjacent communities offered lower-cost housing, the representative posited, then people seeking lower rents would be able to stay in those towns instead of moving to Hartford. The representative based this belief on the theory that increased demand in Hartford for affordable housing drives rent up (Susskind and Podziba, 1990).

Thus education and consciousness-raising became a major part of the negotiation. The education helped to break down stereotypes of housing assistance, both project type and recipient; especially when housing committee representatives discovered that town employees and even their own children could benefit from implementation of various forms of publicly assisted affordable housing in the suburban communities. This personalizing of affordable housing made compromise and collaboration more attainable (Susskind and Podziba, 1990: 8).

Manchester, Marlborough, Newington, Rocky Hill, Simsbury, Somers, South Windsor, Suffield, Tolland, Vernon, West Hartford, Wethersfield, Windsor, and Windsor Locks. 
Through the process of compromise and collaboration, committee members worked on a final agreement for a fair housing compact. Committee members had to find a balance between the concepts of regional fair share and local autonomy while simultaneously recognizing past affordable housing efforts and present needs. Furthermore, the agreement had to be crafted so that it would be accepted and passed by the legislative body of each respective town. Proposals included regional approaches wherein representatives distributed the regional burden of affordable housing to each town according to that town's percentage of the region's total households. Alternatively, local approaches required supplying affordable housing according to each town's individual need. Some representatives combined regional and local approaches. In the end the committee adopted the local approach, with modifications, because members believed that local residents would strongly object to a regional approach (Susskind and Podziba, 1990: 17).

The committee used housing-cost burden as the basis for setting compact goals. Households experience housing-cost burden if they spend more than 30 percent of their income on housing where that income is less than or equal to 100 percent of regional median income (CRCOG, September 1995: 58). The fair housing committee estimated the number of households experiencing a housing cost burden in 1980 (from the U.S. Census), gave credit for any affordable housing added between 1980 and 1989, and then calculated the shortfall in each town. In general, members asked municipalities to accept 25 percent of this 
shortfall as their compact goal although it was possible for municipalities to adjust this goal.

Some towns still felt that 25 percent represented an unrealistic number when compared with local annual housing starts. Therefore, goals were capped in East Hartford, Hartford, Manchester, West Hartford, and Wethersfield so that the Compact would not unduly burden the municipalities by requiring more than 35 percent of a community's average annual building permits issued in each of the last five years (CRCOG, September 1995: 58). Finally, two other formula modifications allowed each town some autonomy in choosing formulas and created the range of housing goals in the final agreement (Susskind and Podziba, 1990: 20). In the end, some towns desired to work with a range and others a fixed number. The final agreement on each municipality's five-year goal is presented below in Table 1.

\section{Table 1 Capitol Region Compact Goals}

\begin{tabular}{lr|lr} 
Municipality & Compact Goal & Municipality & Compact Goal \\
\hline Andover & $6-14$ & Manchester & $500-601$ \\
Avon & $96-100$ & Marlborough & 38 \\
Bloomfield & $167-205$ & Newington & $276-308$ \\
\hline Bolton & $39-44$ & Rocky Hill & $202-214$ \\
Canton & 84 & Simsbury & 160 \\
East Granby & 36 & Somers & $60-64$ \\
\hline East Hartford & $296-637$ & South Windsor & 143 \\
East Windsor & 97 & Suffield & $44-56$ \\
Ellington & $32-65$ & Tolland & $65-88$ \\
\hline Enfield & $434-466$ & Vernon & 327 \\
Farmington & 151 & West Hartford & $281-939$ \\
Glastonbury & 220 & Wethersfield & $212-279$ \\
\hline Granby & 51 & Windsor & $267-297$ \\
Hartford & 582 & Windsor Locks & $86-103$ \\
Hebron & 52 & & \\
\hline
\end{tabular}

* These towns did not join the Compact.

Source: CRCOG September 1995: 59. 
All of this counted towards the goal of creating between 4,583 and 5,637 new units throughout the region over a five-year period. In addition to the abovementioned 35 percent cap placed on Hartford's goal, the agreement further capped the city's actual contribution to the regional total at 582 units, or 12.5 percent of its local shortfall. Representatives constructed this agreement for two reasons: 1) If the settlement counted all of Hartford's contributions, then the City would account for half of the Compact goal and 2) The City had made significant past efforts in providing affordable housing. Annual reports noted any additional units gained in Hartford but did not add them to the regional summary. This made it easier to track one of the fundamental objectives of the Compact: to expand the region's housing opportunity and to reverse the historical concentration of lower-cost units in Hartford (U.S. Department of Housing and Urban Development March 1994: 114). If reports counted all of Hartford's additional units, the regional numeric goal might have been attained at the expense of the regional equity goal.

Each participating municipality committed to making its best effort to increase the supply of affordable housing. That could be done in numerous ways, including new and rehabilitated construction, financing packages, owner and rental housing, and a variety of initiatives. The agreement incorporated initiatives to give housing-unit credit for local strategies designed to increase affordable housing, such as inclusionary zoning, property taxes abatements on affordable units, a housing trust fund, or a local housing committee (CRCOG September 1995: 3-4). While initiatives may not directly add to the number of 
units, they streamlined regulatory processes, or created new programs, so that other direct actions could take place and created a supportive institutional environment for affordable housing.

For both Hartford and its suburbs, each community's numerical assignment allowed specificity and flexibility in the definition of affordable housing for whom. The Compact divided the total housing goal for each municipality as follows:

Share

15 percent

15 percent

15 percent

55 percent

\section{Affordable Housing Definition} affordable to very low-income households (earning 0-50 percent of areawide median) affordable to low-income households (earning $51-80$ percent of areawide median) affordable to moderate-income households earning 81-100 percent of areawide median) affordable to any mix of very low, low, and/or moderate income, as defined above

After the committee finished negotiations, the legislative body of each community had to approve the agreement; four communities rejected it, although one ultimately reversed itself and voted for acceptance. The result of the negotiation was the 26-town Capitol Region Fair Housing Compact on Affordable Housing (CRFHC or Compact).

\section{Current status of the Compact}

In the first half of the 1990s, decreases in homes sales prices, interest rates, and rents have eased the housing-cost burden for some. However, rapid 
changes in the job market, mismatches between skills of the under- and unemployed and job availability, and layoffs and downsizing have all led to an increased burden on others. Unfortunately, no data exist on the net impacts of these changes (CRCOG, September 1995: 60).

Overall there has been some success, some failure, and some interest in continuing the Compact. The five year agreement for the Compact expired March 31,1995 . In the final accounting, the Compact helped to provide 4,657 new affordable housing opportunities. In sum, the municipalities achieved 102 percent of the minimum goal and 83 percent of the maximum regional goal. Progress by type of activity was: 15 percent new family units, 12 percent new elderly units, 16 percent rehabilitated units, 34 percent new mortgage assistance, 21 percent new rental assistance certificates, and 3 percent initiatives. Ten (or 38 percent) of the 26 communities participating in the Compact met or exceeded their individual minimum municipal goals both numerically and according to income divisions. Progress for other towns ranged from 12.5 to 95.8 percent (CRCOG, September 1995).

While the region achieved the minimum compact goal, 16 communities have not yet met their individual municipal goals. Add to this the fact that the original goal only targeted at most 25 percent of the local shortfall in affordable housing. Finally, with regional labor markets ( 89.3 percent of the region's working residents both live and work in the region), reductions in state and federal subsidies, and still-high housing costs (Hartford area still exceeds many 
northeast metropolitan areas as well as areas in the south and west), the need continues for more affordable housing.

Recognizing the work that still needs to be done, the CRCOG Policy Board extended the term of the Capitol Region Fair Housing Compact to the Capitol Region Policy Board until June 30, 1996, or until the Board adopts a new regional housing policy (CRCOG Housing Committee November 6, 1995).

During that year, CRCOG staff gathered more information to assess the current market situation and impacts of ongoing programs. Staff and Board members estimate that more units are vacant now, either for sale or rent, than in 1989 and therefore it makes sense to utilize tenant-based programs, such Section 8 , that can fill vacant units.

\section{Context and background}

This section provides a brief description of the Capitol Planning Region and the individual municipalities in order to set this study in its geographic and demographic context.

\section{Regional profile}

The race and ethnicity distribution of the Capitol Planning Region, according to the 1990 U.S. Census, is 82.5 percent White, 11.4 percent Black, less than 2.0 percent Asian/Pacific Islander, 4.5 percent other, and 8.1 percent Hispanic of any race (MA State Data Center/MISER). The region had a 1995 unemployment rate of 5.4 percent (CRCOG, September 1995: 62). Fifty-five 
percent of housing units consist of detached single-family units. The Region is 15.2 percent of the state's land area and has a population density in 1990 of 930 persons per square mile, compared to the state's density is 656 persons per square mile (CT Department of Economic Development). Employment is predominately in such fields as insurance, medicine, technology, manufacturing, retail, government, and service sector jobs. The Capitol Region is also home to the state's major airport.

\section{Municipal profiles}

The Capitol Region, bisected by the Connecticut River, is a mixture of rolling hills and river valley. It is primarily a suburban area with a central urban city and outlying rural towns. The geographic size of the municipalities run from Windsor Locks' 9.2 square miles to Glastonbury's 52.5 , with half smaller than 25 square miles.

The population of the individual municipalities ranges from the small town of Andover to the city of Hartford. In between are eight towns with an estimated 1992 population of 10,000 or less, eight more towns in the 10,001 to 20,000 range, another eight ranging from 20,001 to 30,000 , and two each in the 40,001 to 50,000 and 50,001 to 60,000 categories.

Since the 1990 U.S. Census of Population, the Census Bureau estimates that the city of Hartford has lost about six percent of its population. Of the six 
Table 2 Population, Area, and Density by Town

\begin{tabular}{lrrrrr} 
Municipality & 1992 Est. Pop. & Rank & Area & Rank & Density \\
\hline Andover & 2,605 & 29 & 15.6 & 22 & 167 \\
Avon & 14,284 & 16 & 23.5 & 16 & 608 \\
Bloomfield* & 19,296 & 14 & 26.4 & 14 & 731 \\
\hline Bolton & 4,643 & 27 & 15.5 & 23 & 300 \\
Canton & 8,409 & 24 & 25.0 & 15 & 336 \\
East Granby & 4,388 & 28 & 17.4 & 21 & 252 \\
\hline East Hartford* & 49,707 & 4 & 18.7 & 18 & 2,658 \\
East Windsor & 10,123 & 21 & 26.8 & 13 & 37,811 \\
Ellington* & 11,179 & 20 & 34.8 & 6 & 321 \\
\hline Enfield & 45,643 & 5 & 33.8 & 8 & 1,350 \\
Farmington & 21,549 & 13 & 28.7 & 10 & 751 \\
Glastonbury & 28,506 & 8 & 52.5 & 1 & 543 \\
\hline Granby & 9,534 & 22 & 41.3 & 3 & 231 \\
Hartford* & 131,995 & 1 & 18.4 & 20 & 7,174 \\
Hebron & 7,369 & 25 & 37.5 & 5 & 197 \\
\hline Manchester & 52,118 & 3 & 27.2 & 12 & 1,916 \\
Marlborough & 5,674 & 26 & 23.5 & 16 & 241 \\
Newington* & 29,140 & 7 & 13.2 & 25 & 2,208 \\
\hline Rocky Hill & 16,699 & 15 & 13.9 & 24 & 1,201 \\
Simsbury & 22,253 & 12 & 34.5 & 7 & 645 \\
Somers & 9,262 & 23 & 28.7 & 10 & 327 \\
\hline South Windsor & 22,834 & 11 & 28.5 & 11 & 801 \\
Suffield & 11,634 & 18 & 43.1 & 2 & 270 \\
Tolland & 11,217 & 19 & 40.4 & 4 & 280 \\
\hline Vernon* & 29,389 & 6 & 18.6 & 19 & 1,580 \\
West Hartford* & 59,724 & 2 & 22.2 & 17 & 2,690 \\
Wethersfield $^{*}$ & 25,909 & 10 & 13.0 & 26 & 1,993 \\
\hline Windsor & 28,287 & 9 & 31.1 & 9 & 910 \\
Windsor Locks & 12,396 & 17 & 9.2 & 27 & 1,347 \\
\hline Total $^{*}$ & 705,766 & & 763.0 & & 930
\end{tabular}

* These towns are estimated to have lost population since 1990.

Source: CRCOG July 1995. 


\section{Figure 1 Capitol Planning Region}

Connecticut

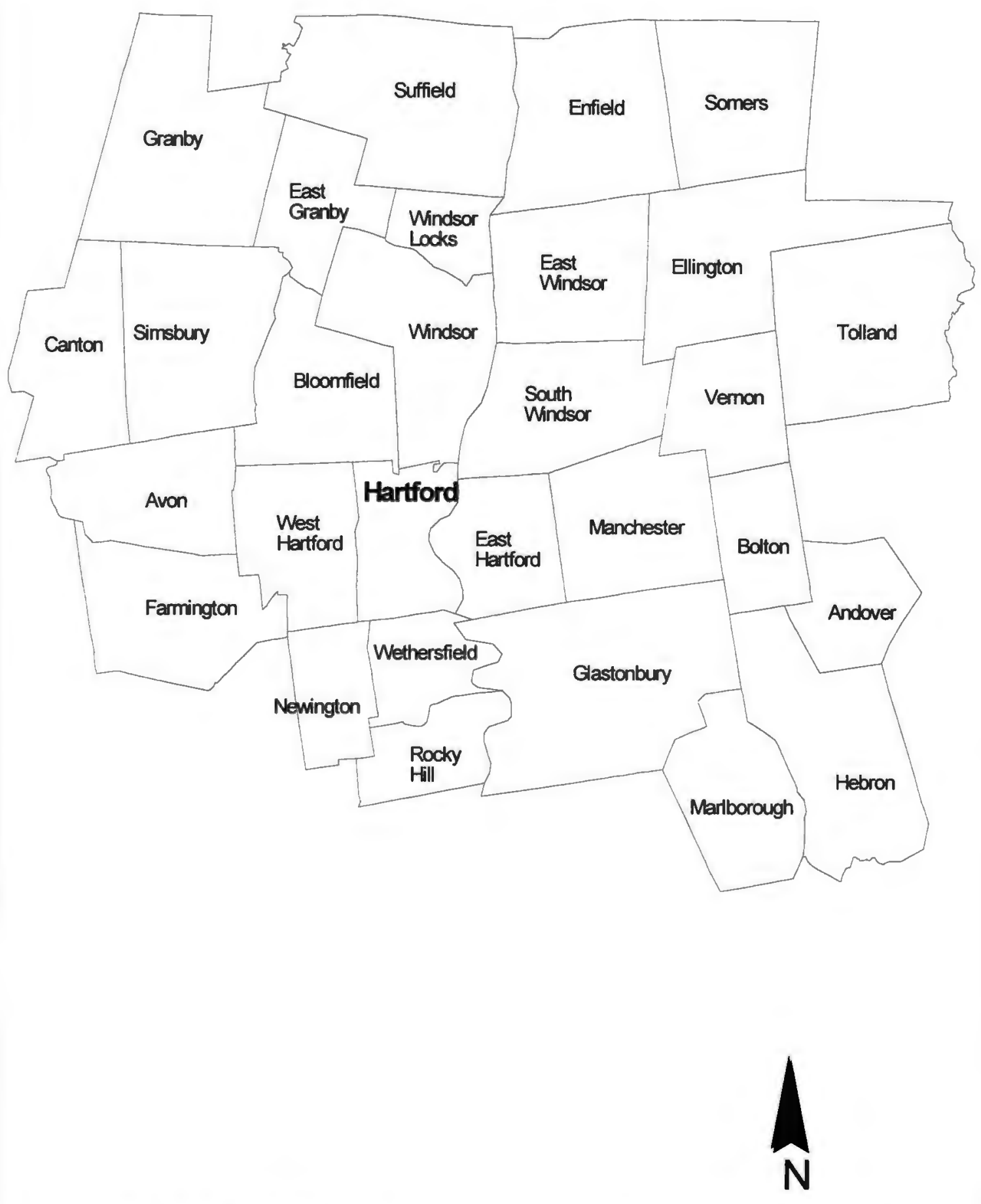

0123456 Miles

Source: Boundaries from 1994 U.S. TIGER files. 
other towns that show slight decreases in population (less than 1.5 percent), four share a border with Hartford (CRCOG July 1995) (Table 2 and Figure 1).

Housing prices for both median rent and median sales prices vary throughout the Region. ${ }^{2}$ Only two municipalities had a 1990 median contract rent of $\$ 500$ or less, and one of these was Hartford. Contract rent in thirteen towns ranged between $\$ 501$ and $\$ 600$, eleven towns between $\$ 601$ and $\$ 700$, and three were greater than $\$ 701$ (CRCOG, July 1995). Median home sales price for the Region was $\$ 130,000$. The lowest median sales price was in Hartford $(\$ 81,500)$ and the highest in Avon $(\$ 250,000)$. The median sales price in twenty-one of the municipalities was $\$ 150,000$ or under. It is important to note, however, that the Capitol Region has undergone a strong economic downturn since 1990 that has greatly modified both rents and sales. While the effect on rents is not yet assessed, the home sales price is more easily tracked. The high-end house price has not changed significantly since 1991 but the lowend has dramatically decreased (Table 3).

Table 3 Range of Municipal Median Sale Prices Fiscal Year 1991 to Fiscal Year 1995

\begin{tabular}{lllll} 
FY 1991 & FY 1992 & FY 1993 & FY 1994 & FY 1995 \\
\hline 124,800 to & 115,000 to & 100,000 to & 94,000 to & 81,500 to \\
240,000 & 225,000 & 242,000 & 186,125 & 250,000
\end{tabular}

Source: Capitol Region Council of Governments. 1995. Home sales prices: July 1, 1994 through June 30, 1995. September.

\footnotetext{
${ }^{2}$ The most recent available information for rental records is the 1990 Census of Population median contract rent. Median home sales prices are from the Home Sales Prices: July 1, 1994, through June 30, 1995 produced by the Capitol Region Council of Governments. Median price reflects condominium as well as one, two, and three family units.
} 
The race/ethnicity and income distribution of the towns is typical of many urban/suburban areas. As shown in Table 4, the central city of Hartford has the highest concentration of people of color.

Table 41990 Capitol Region Population Percentages by Race

\begin{tabular}{lrrrrr} 
Municipality & $\begin{array}{r}\text { Percent } \\
\text { White }\end{array}$ & $\begin{array}{r}\text { Percent } \\
\text { Black }\end{array}$ & $\begin{array}{r}\text { Percent } \\
\text { AlE* }\end{array}$ & $\begin{array}{r}\text { Percent } \\
\text { API }\end{array}$ & $\begin{array}{r}\text { Percent } \\
\text { Hispanic (of } \\
\text { any race) }\end{array}$ \\
\hline Andover & 99.3 & 0.1 & 0.4 & 0.2 & 1.1 \\
Avon & 97.2 & 1.1 & 0.0 & 1.5 & 0.8 \\
Bloomfield & 56.0 & 41.6 & 0.0 & 1.3 & 2.8 \\
\hline Bolton & 96.6 & 1.7 & 0.0 & 1.1 & 1.3 \\
Canton & 98.6 & 0.8 & 0.0 & 0.5 & 1.1 \\
East Granby & 98.5 & 1.0 & 0.0 & 0.5 & 1.4 \\
\hline East Hartford & 86.8 & 8.5 & 0.3 & 2.0 & 5.4 \\
East Windsor & 93.0 & 3.7 & 1.3 & 0.9 & 1.6 \\
Ellington & 98.2 & 1.3 & 0.2 & 0.2 & 0.4 \\
\hline Enfield & 96.0 & 2.4 & 0.0 & 1.0 & 2.2 \\
Farmington & 96.4 & 1.3 & 0.0 & 2.0 & 1.1 \\
Glastonbury & 96.3 & 0.8 & 0.0 & 2.3 & 1.7 \\
\hline Granby & 98.7 & 0.2 & 0.2 & 0.6 & 0.9 \\
Hartford & 39.9 & 38.9 & 0.4 & 1.5 & 31.0 \\
Hebron & 98.4 & 0.4 & 0.6 & 0.4 & 0.9 \\
\hline Manchester & 93.6 & 4.0 & 0.4 & 1.4 & 2.0 \\
Marlborough & 99.2 & 0.4 & 0.0 & 0.3 & 1.2 \\
Newington & 97.3 & 1.3 & 0.0 & 1.1 & 2.1 \\
\hline Rocky Hill & 95.8 & 2.5 & 0.3 & 1.1 & 2.2 \\
Simsbury & 97.8 & 0.5 & 0.0 & 1.5 & 1.3 \\
Somers & 91.1 & 7.7 & 0.2 & 0.2 & 3.1 \\
\hline South Windsor & 94.6 & 2.7 & 0.0 & 2.3 & 1.6 \\
Suffield & 97.5 & 1.6 & 0.0 & 0.8 & 0.9 \\
Tolland & 97.2 & 1.1 & 0.0 & 1.0 & 0.8 \\
\hline Vernon & 94.6 & 2.2 & 0.1 & 2.4 & 1.8 \\
West Hartford & 94.2 & 1.8 & 0.2 & 2.9 & 3.2 \\
Wethersfield & 98.4 & 0.9 & 0.0 & 0.7 & 1.2 \\
\hline Windsor & 78.9 & 17.2 & 0.2 & 2.4 & 3.1 \\
Windsor Locks & 95.9 & 1.3 & 0.0 & 1.7 & 1.8 \\
\hline AIE A & & & & &
\end{tabular}

* AIE = American Indian/Eskimo

*API = American Pacific Islander

Source: U.S. Census. 1990. STF1 Table P1 
Table 5 combines income data with educational attainment statistics. In comparing educational attainment of those age 25 or older with a high school degree, all but five of the municipalities have a rate of 80 percent or higher. Of the five, the percentages for four of them fall in the seventies; high school graduation attainment is lowest in Hartford, at 59.5 percent (CRCOG, July 1995).

The disparity in median household income is large between Hartford and the 28 towns. Hartford's 1989 median household income is $\$ 22,140$. The next closest town is Hartford's neighbor, East Hartford, with $\$ 36,584$. Of the remainder of the towns, 12 have a 1989 median income in the $\$ 40,000-\$ 49,999$ range, 12 more in the $\$ 50,000$ - $\$ 59,999$, and three with more than $\$ 60,000$ (CRCOG, July 1995). Table 5 ranks each municipalities by the two statistics from lowest to highest and then stratifies the towns into low, medium, uppermedium, and high levels. There is a strong correlation with educational attainment and household income. Of the 12 municipalities with the lowest median household income, nine also have the lowest educational attainment. Avon and Simsbury are at the highest level with median income over $\$ 60,000$ and education attainment over 92 percent. 
Table 5 Rank by Socio-Economic Status

\begin{tabular}{llllll}
\hline $\begin{array}{lll}\text { SES } \\
\text { Level }\end{array}$ & Municipality & $\begin{array}{c}\text { HHMedian } \\
\text { Income }\end{array}$ & $\begin{array}{l}\text { Inc. } \\
\text { Rank }\end{array}$ & $\begin{array}{c}\text { Educational } \\
\text { Attainment* }\end{array}$ & $\begin{array}{l}\text { Ed. } \\
\text { Rank }\end{array}$ \\
\hline Low & Hartford & $\$ 22,140$ & 1 & 59.5 & 1 \\
& East Hartford & $\$ 36,584$ & 2 & 73.8 & 2 \\
\hline Medium & Manchester & $\$ 40,290$ & 3 & 83.6 & 12 \\
& Vernon & $\$ 40,543$ & 4 & 81.0 & 8 \\
& East Windsor & $\$ 40,888$ & 5 & 77.7 & 4 \\
& Windsor Locks & $\$ 43,593$ & 6 & 77.3 & 3 \\
& Wethersfield & $\$ 43,888$ & 7 & 80.0 & $6^{\text {b }}$ \\
& Enfield & $\$ 44,635$ & 8 & 78.4 & 5 \\
& Newington & $\$ 45,481$ & 9 & 80.0 & $66^{\text {b }}$ \\
& Bloomfield & $\$ 47,853$ & 11 & 81.4 & 9 \\
& Windsor & $\$ 50,228$ & 15 & 82.1 & 10 \\
& Rocky Hill & $\$ 48,125$ & 12 & 85.3 & 12 \\
\hline Upper & Ellington & $\$ 45,604$ & 10 & 88.3 & 18 \\
& Andover & $\$ 48,289$ & 13 & 90.0 & 22 \\
& West Hartford & $\$ 49,642$ & 14 & 87.3 & 16 \\
& Windsor & $\$ 50,228$ & 15 & 82.1 & 10 \\
& Suffield & $\$ 50,714$ & 16 & 87.5 & 17 \\
& Bolton & $\$ 51,352$ & 17 & 91.9 & 27 \\
& East Granby & $\$ 52,317$ & 18 & 87.1 & 15 \\
& Somers & $\$ 52,970$ & 19 & 82.9 & 11 \\
& Farmington & $\$ 52,979$ & 20 & 88.9 & 20 \\
& Canton & $\$ 53,449$ & 21 & 90.2 & 23 \\
& Hebron & $\$ 56,093$ & 22 & 91.6 & 25 \\
& Tolland & $\$ 56,120$ & 23 & 89.9 & 21 \\
& Glastonbury & $\$ 57,464$ & 24 & 90.6 & 24 \\
& South Windsor & $\$ 57,606$ & 25 & 88.4 & 19 \\
& Granby & $\$ 58,839$ & 26 & 91.7 & 26 \\
& Marlborough & $\$ 60,635$ & 27 & 86.1 & 14 \\
\hline Simsbury & $\$ 64,538$ & 28 & 94.5 & 29 \\
& Avon & $\$ 66,602$ & 29 & 92.7 & 28 \\
\hline
\end{tabular}

a Percent 25 and older with at least a high school diploma.

b Indicates a tie

Source: CRCOG July 1995. 


\section{Housing mobility and portability programs}

\section{What is housing mobility?}

Stratification of neighborhoods and municipalities by income and race is a typical characteristic of urban areas in the United States (Galster 1992). As the above data support, the Capitol Region certainly exhibits this pattern. Housing advocates design mobility programs to overcome this history of segregation by allowing recipients of local, state, or federal housing assistance to move between neighborhoods (central city to suburb, suburb to suburb, city to city, or intra-city). Housing mobility programs are an example of "people-oriented" programs as opposed to unit-oriented programs. They help residents, generally people of color from the central city, to move to the suburbs. The goals include overcoming spatial mismatch in job locations and workers, escaping the negative effects of poverty neighborhoods, and promoting regional racial and economic integration (Polikoff 1995). Eligibility standards commonly use national criteria for HUD Section 8 Income Limitations by household size. Those eligible for assistance are households whose income is below some fraction of the area median income, generally 80 percent.

\section{Housing mobility debates}

Much of the debate in affordable housing movements today is over lowincome people's choice of living location and their ability to overcome socioeconomic neighborhood stratification (Donovan 1993, Fischer 1991, Galster and Hill 1992, Polikoff 1995, Rosenbaum and Popkin 1991). There is general 
agreement that public housing offers limited choices. The Department of Housing and Urban Development under Secretary Henry G. Cisneros has proposed to phase out traditional public housing and replace it with expanded programs of housing certificates which poor households could use anywhere in a metropolitan region (Polikoff 1995).

However, the most intense debate over these programs is not focused on a choice between traditional public housing or mobility programs. Instead, the concerns revolve around four main debates about particular aspects and impacts of mobility programs. The first is "place-oriented versus people-oriented," which describes the discussion over rebuilding poor inner-city neighborhoods or enabling those in deteriorated neighborhoods to leave (Donovan 1993). Second is scale effectiveness: the ability of mobility programs to incorporate all those in need and, even if that were possible, whether that would work against program success. For instance, in 1990 there were 5.9 million black residents living in urban census tracts where the black poverty rate was at least 40 percent. By contrast, special mobility programs have reached only 12,000 residents.

Furthermore, it is suggested these programs cannot work if they get bigger. They are effective precisely because their small size mitigates local resistance and retains neighborhood characteristics (Polikoff 1995: 11). The third concern is results effectiveness. This asks whether a move in and of itself can change or improve people's lives (Polikoff 1995: 10). The last is "creaming", a reference to the potential for programs to benefit the most favorably situated of those eligible and to skim the best of that class out of the central city. 
This paper does not try to assess or support any of these debates.

Instead, it is concerned with the destination outcome of local programs. This study asks if there is concentration in particular census tracts and whether any neighborhood characteristics can be associated with such concentration. To find the answer, it asks whether destination tracts were improving, stable, or declining before mobility programs began and compares these tracts to other tracts without mobility residents.

\section{Capitol Region programs}

Several programs are designed to achieve mobility goals, from basic Section 8 portability to special mobility programs. This study examines several regional programs that facilitate the movement of poor households from one area to another. For simplicity, the term portability is used to describe any of these movements. The individual programs are briefly described below.

The Housing and Community Development Act of 1974 first authorized federal Section 8 certificates. They are normally issued by Public Housing Authorities (PHAs) or private housing firms contracted by the municipality. Households can only use certificates in units which do not exceed the area HUDassigned Fair Market Rent (FMR). Recipients pay no more than ten percent of gross income, 30 percent of net income, or welfare rent; ${ }^{3}$ the PHA, funded

\footnotetext{
${ }^{3}$ The welfare rent rule applies in certain states in which AFDC payments include an allowance for rent equal to the AFDC family's out-of-pocket expenses for rent up to a maximum amount, called the welfare rent. In these states, housing assistance payments that reduce the tenant contribution of AFDC recipients below the welfare rent would be offset dollar for dollar in reduced AFDC payments. Therefore, in these areas, the Certificate program sets the tenant contribution for AFDC recipients equaled to the which ever is the larger payment: $30 \%$ of net, $10 \%$ of gross, or welfare rent (U.S. Dept. of Housing and Urban Dev. 1994: 3).
} 
through the federal government, pays the remainder. As originally conceived, Section 8 certificates could only be used in the issuing authority's jurisdiction. In 1987, Congress amended the terms of Section 8 certificates to make them "portable." Portability allows recipients to use the certificates throughout the contiguous metropolitan area through inter-jurisdictional agreements with Public Housing Authorities (U.S. Department of Housing and Urban Development October, March 1994).

In 1983, the Housing and Urban/Rural Recovery Act authorized Section 8 vouchers. Unlike certificates, vouchers can be used anywhere in the country and for units that exceed the FMR. PHAs still only pay the difference between the payment standard and the FMR. As tenants pay the excess rent above FMR; it is possible that some could spend a considerable percentage of their income on rent. However, tenants pocket the difference if they find a unit cheaper than the FMR.

With both vouchers and certificates, the PHA certifies that the rent charged by the landowner is reasonable and that certain building standards are met. Both allow guarantees to landowners for damages and abandonment.

\section{Hartford Special Mobility program}

The Hartford Special Mobility Program is a unique application of Section 8 portability. In 1990 the Connecticut Civil Liberties Union Foundation and the Hartford Legal Aid Society charged that the City of Hartford was not administering certificates to permit as much portability as the 1987 law change 
allowed. These advocates asserted two facts: 1) that Hartford housing agencies did not inform certificate holders that they could use their certificates outside Hartford, and 2) that other jurisdictions invoked portability only in certificate "swaps" between municipalities (Donovan 1993, Polikoff 1995). Instead of going through the courts, CCLU and Hartford housing authorities devised a program that took advantage of Hartford's management of certificates in the city Department of Housing rather than in its PHA (Donovan 1993, Polikoff 1995, U.S. Department of Housing and Urban Development March 1994). The city Department of Housing, unlike the PHA, could legally enter into agreements with landowners in other jurisdictions. This became the mobility program and is administered by Imagineers, Inc., a private-for-profit real estate management firm that manages the city's and three other Capitol Region towns' Section 8 programs.

From the standpoint of the user, both portability and mobility programs are the same. The difference lies in the administration, with the mobility program much less bureaucratic. Portability regulations require that the originating agency ("originator") work with the receiving agency ("receiver") to administer the certificate. The originator contacts the receiver to notify it that a certificate holder seeks to move to the town. Once a unit is rented, the receiver pays the rental difference to the landowner. The administrative fee is split, with 80 percent going to the receiver.

In contrast to this, the Hartford Special Mobility Program administration stays with the originating agency, in this case, Imagineers. The certificate or 
voucher holder advises Imagineers of his or her desire to move outside of Hartford and finds a unit. Hartford, through Imagineers, pays the rental difference to the landowner and receives the full administrative fee. Every town around Hartford has agreed to use the Hartford mobility mechanism for the city's Section 8 certificates except West Hartford, which continues to use the portability administration. This is a policy preference of the West Hartford PHA because that PHA wants both access to the 80 percent fee and the ability to track those using subsidies within town borders (Donovan 1993). The following are highlights of the Hartford Special Mobility Program.

- Applies to all Hartford Section 8 certificate and voucher holders. Recipients are told of options when they enter the program.

- No racial mix requirements or Section 8 concentration limits.

- Two levels of counseling: Imagineers informs all recipients of the program and provides suburban maps, newspapers, bus routes, and apartment listings. Since 1992, the Housing Education Resource Center (HERC) has provided additional counseling and support services. HERC operates independently of Imagineers and provides van tours, shows units, and helps match tenants with child care, social services, and transportation in suburban towns.

- The program has concentrated on moves to the suburbs, though intracity moves are also possible (Polikoff 1995).

\section{State programs}

The State offers two rental assistance programs. The first is the State allotment of federal Section 8 certificates and vouchers. This is run according to the same guidelines listed previously: all certificates/vouchers are portable, tenants can use certificates regionwide and vouchers in a national market, fair market rents apply, and property owners must meet building standards. 
Approximately 1,000 households use these certificates throughout the Capitol Region. Currently Hartconn, a private, for-profit company, administers these programs for the State Department of Housing. However, Community Renewal Team, another private administrator, is in the process of taking over this service.

The second State program is the state-funded Rental Assistance Program (RAP), administered by the Community Renewal Team (CRT). RAP accounts for about 500 regional certificates and uses similar guidelines as the Section 8 program. State legislation originally authorized for the RAP program to provide housing for families that did not qualify for Section 8 . However, debates over the focus of the program have occurred since its inception, with its unpopularity resulting in regular funding cuts. CRT closed the lists in 1993 and the program is now slated for termination over the next two to three years. No plans are in place for the clients now relying on this program. Unfortunately for this study, because both these programs are state, rather than municipal programs, neither one tracks portability as direct moves between cities/towns. Therefore, the certificates can only be counted as assisted housing rather than as specifically identified mobility moves.

\section{Suburban programs}

Not every town in the region has a Public Housing Authority, and some of those that do deal only with elderly fixed-site housing. The towns that administer Section 8 certificates and vouchers do so according to the general guidelines provided above. Those towns are: East Hartford, Enfield, Farmington, 
Glastonbury, Manchester, West Hartford, Vernon, Windsor, and Windsor Locks. In addition, Imagineers administers the Section 8 programs for Newington, South Windsor, and Wethersfield. None of these towns has a special mobility program; all have some portability moves. Imagineers administers most of Hartford's Section 8 allotment although there is a public housing authority that administers a relatively small amount of certificates and vouchers. 


\section{CHAPTER THREE: RESEARCH DESIGN AND METHODOLOGY}

This chapter describes the tools used to undertake this study. First comes a review of some regional census tract factors. The second section lists the research questions addressed in this report. A summary of the methods follows in the third section. The final section describes some research limitations.

\section{Introduction to analysis}

The geographic level of census data chosen for this report were census tracts, specifically those tracts within the Capitol Region of Connecticut. This is one of 15 planning regions within Connecticut and the one under the purview of the Capitol Region Council of Governments. This region comprises 29 towns from portions of both Hartford and Tolland Counties.

The population size of a census tract ranges up to 8,000 but averages around 4,000 persons. As of 1990 the Capitol Region consisted of 193 census tracts (Figure 2). In several of the outlying, small, rural towns, the entire town contains only one census tract. ${ }^{4}$ Five others have only two census tracts. ${ }^{5}$ By contrast, Hartford has 49 tracts. This wide range of census tract division within the municipalities may seem to create difficulties for comparability between communities. However, the towns which have received the bulk of portable moves and have expressed the most concern about possible town changes are

\footnotetext{
${ }^{4}$ These towns are Andover, Bolton, East Granby, Hebron, and Marlborough.

${ }^{5}$ These are Canton, East Windsor, Ellington, Granby, and Tolland.
} 


\section{Figure 2 Census Tract Boundaries}

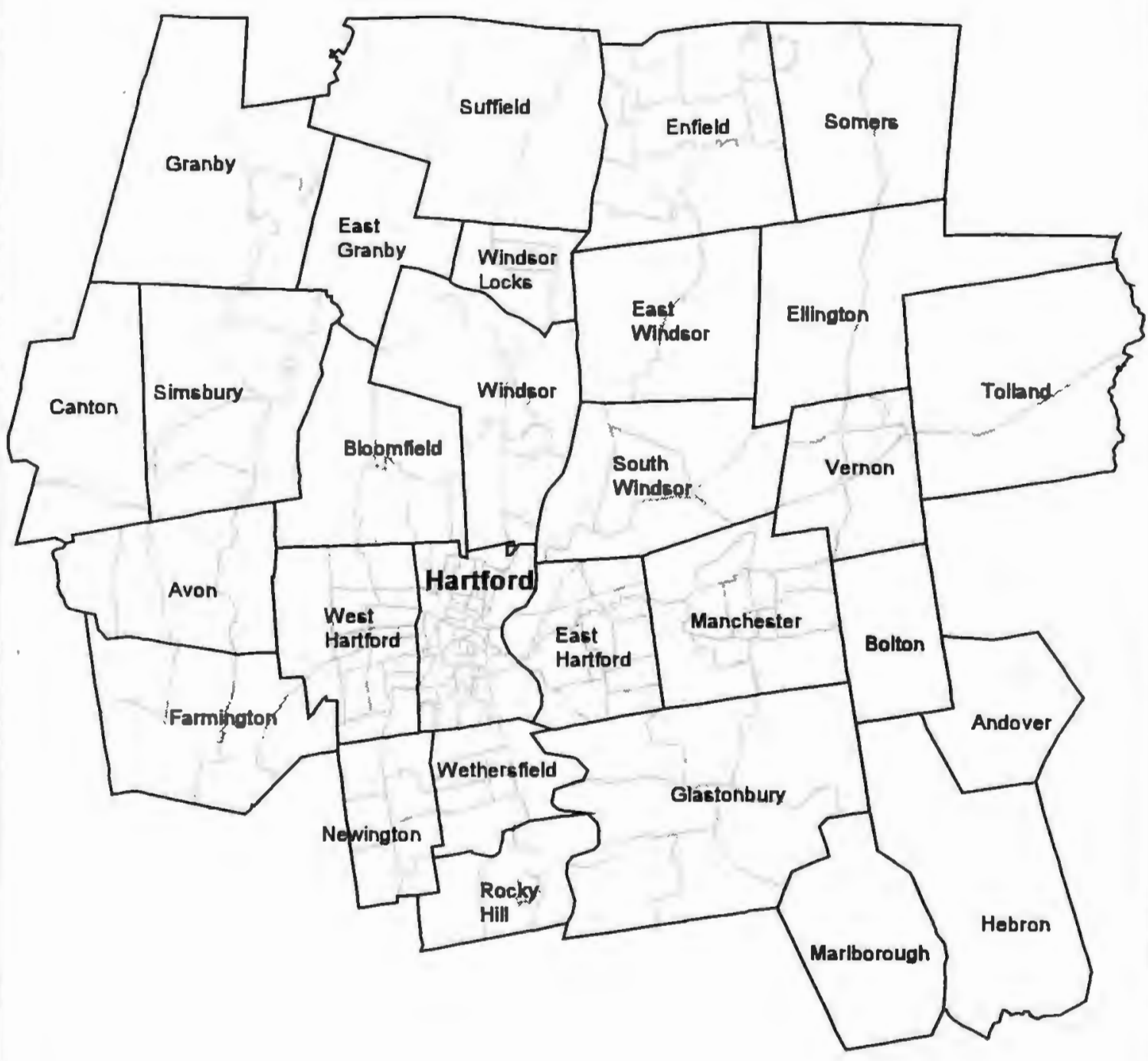

Tract Boundaries

Municipal Boundaries

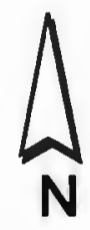

$0 \begin{array}{lllllll}0 & 1 & 3 & 4 & 5 & 6 & \text { Miles }\end{array}$

Source: Boundaries from 1994 U.S. TIGER files. 
comparable in the number of census tracts as well as other characteristics.

Similarly, towns with little tenant-based rental assistance activity have certain size and demographic traits in common.

Hartford, the geographic center of the region, is also the center of rental assistance activity with almost seven times as many certificates as the next closest town. ${ }^{6}$ The city, while clearly at the heart of regional concentration, is not part of this analysis for intra-town concentration. This is partly because of the large number of certificates in Hartford and the unavailability of these data in a form suitable for mapping. However, the primary reason for a more suburban emphasis is because the locus of concern over tenant-based assistance has come from these communities, particularly the inner ring towns of the Capitol Region. In addition, the U.S. Department of Housing and Urban Development (HUD) is considering the elimination of all project-based rental housing assistance in favor of portable tenant-based rental assistance (Polikoff, 1995: 2). It is therefore crucial to look at the areas which will be the most affected by such policy changes.

\section{Research questions}

The following list presents the research questions targeted in this study.

1) Tenant-based rental assistance concentration: Does it exist, how is it defined, where is it located?

This study seeks to examine concentration of rental assistance in two different venues. The first is concentration on a regional basis. In this context, 
one looks at which geographic areas of the Capitol Region house the majority of certificate holders. The second venue for concentration is intra-town concentration. Chapter Five describes areas of concentration within selected towns as well as regionally. Concentration is defined in several ways, as discussed in full in Chapter Five. But to sketch the concept, the study utilizes HUD criteria based on race/ethnicity and income. In addition, the study measures race and economic concentration using a regional standard. In both cases, the analysis combines race and income with the number of certificates in each tract. Finally, the study utilizes a chi-square analysis in both instances to determine whether certificate holders are concentrated in low-income and minority neighborhoods.

2) Is the outcome of one aspect of tenant-based assistance different from other forms of tenant assistance?

This report examines the location of all tenant-based units throughout the Capitol Region, not simply portable certificates. This enables the reader to consider two features. The first is a comparison of the results of one aspect of the program to another. In doing so, the study detects whether certificate households moving into a town, through either Hartford Special Mobility or the regular portable programs, live in the same or different neighborhoods than town-based participants. Second, is a comparison of the combined outcome of all programs with all households in the population. This allows for an examination of the

\footnotetext{
${ }^{6}$ Hartford has 4170 certificates in use in the city and East Hartford 616.
} 
distribution patterns in general. Both parts of this question are covered in Chapter Five.

3) Are certificate/voucher holders moving to neighborhoods that were either pockets of poverty in 1990 or closer to that status in 1990 than they had been in $1980 ?$

One of important goals of the portability programs is to increase the options that certificate holders have to find better living environments. Census data provide a reliable, albeit somewhat dated, source to answer this question. The study also uses census data to investigate change. However, Congress did not legislate the portability of Section 8 certificates until 1987. Nonetheless, it is still possible to have some changes show up in a comparison of 1980 and 1990 census data. To further complicate matters, the Hartford Special Mobility Program did not begin until 1990, after the last census. The 2000 census will mark the impact of this program, but measurements between the censuses are more difficult. However, a comparison of 1980 and 1990 census information is still valuable to show patterns of change in the region. It is important to know whether the region as a whole became more or less hospitable to renters seeking affordable housing and whether the number of distressed neighborhoods were growing or declining throughout the decade. Furthermore, an analysis of the 1990 situation that focuses on rental assistance is a useful base for comparison with the year 2000 census when the portable programs will have had 10 years of operation. Chapter Four answers the question of improving or decaying environments. 
4) What opportunities exist for dispersion of certificate holders to underutilized tracts?

By utilizing the results of the census data in combination with the mapped units, the report identifies underused areas and targets areas for future destination tracts. However, it is crucial to keep in mind that in the end we are talking about people. People, regardless of income level, move for a wide range of reasons: to live in better neighborhood, for better schools, to be near friends and families, and many more. While public policy can open opportunities, it cannot force the outcomes. The question of under-utilization and opportunity is responded to in Chapters Four, Five, and Six.

\section{Summary of methods}

\section{Modeling}

\section{An indicator model}

Both Land and Spilerman (1975) and Rossi and Gilmartin (1980) advise creating a model utilizing indicators to measure the impact of programs in a complex society. This distinguishes between input, context, process, and output indicators as well as descriptive and analytic indicators. The model presented here is based on both sources.

Context variables are those events or shifts that describe what is happening in the policy environment. Input indicators are a combination of directly manipulable policy variables, such as funding, and indirectly manipulable variables, such as individual choices. Process variables are the policy in action. 
Output variables measure the output of the policy and are assumed to be related to an end-product of the policy (Rossi and Gilmartin, 1980: 22).

The researcher's image of the model devised for this report is non-linear. Change - whether in input, process, output, or context variables -- reverberates throughout the system and impacts other variables in the system. With this in mind, the analysis sets context indicators at the center of the model with context repercussions felt in all indicators. Next, in a circle around the context indicators, are input, process, and output indicators with ongoing interactive effects among them. The picture is given below.

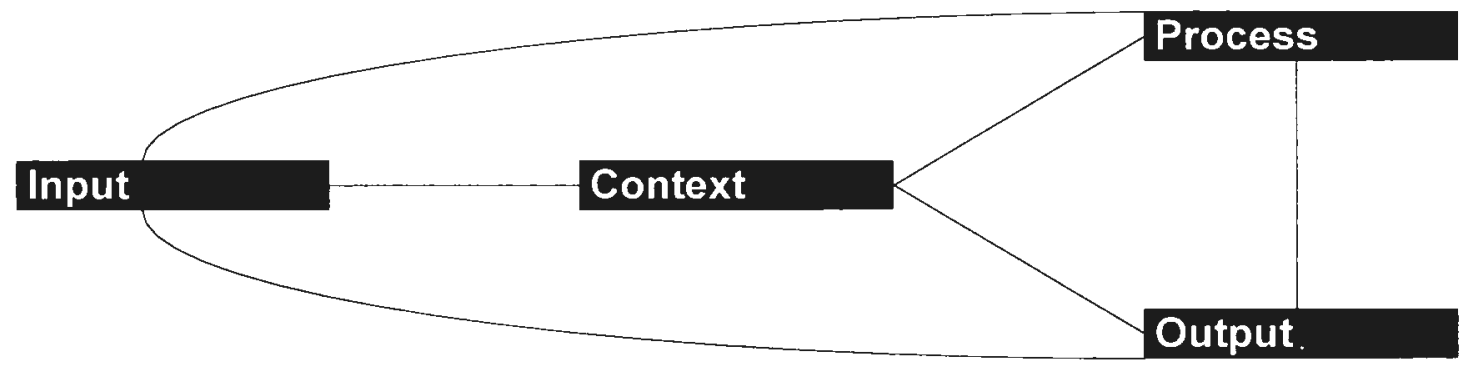

To illustrate how the model works, consider the case of the Capitol Region Fair Housing Compact. The context in 1988 was that a lack of attention in the suburban communities to affordable housing issues combined with a decade of boomtime economics had rendered many of these communities inaccessible to those with low and moderate income (CRCOG, 1995 58). Context measurements included the cost and amount of housing. The process was the Compact, a 26town agreement which contained a multitude of ways in which to increase affordable housing options. Examples of input variables would be zoning changes 
and funding allotments. The output measurement is the increase in the number of affordable housing units.

The tenant assistance model

Since this report focuses on tenant-based rental assistance, a subset of the Compact, the indicators are structured slightly differently. Section 8 and other tenant-based assistance programs rely on the private market provision of housing; thus the context is focused on characteristics that relate to rental properties. An analysis of rental properties is used both for context indicators, that is, to display the status quo, and for manipulable input indicators; that is, to identify areas of opportunity at which policy could be directed. The statistics that together make the rental desirability indicator are: the amount of rental property, the affordability of rental property, the amount of all rental property that is vacant, and the number of school-age children. Detail about and rationale for each is provided later.

The second indicator set, distressed neighborhoods, is also a context indicator intended both to display the environment from the perspective of the recipients and to show the location of distress. The statistics, discussed at length below, are female head of household, households on public assistance, unemployment, poverty, and teenage high school dropouts.

Potential process indicators were not measured, although they could include counseling programs that educate movers on possibilities outside the municipality of certificate origin. Imagineers, Inc., which administers the Hartford Special Mobility Program, incorporates some degree of counseling into their 
program. In addition, the Hartford Foundation for Public Giving funds the Housing Education and Resource Center whose specific goal is to increase awareness among Hartford residents with housing assistance that there are a number of municipalities from which renters have to chose. This author is not aware of the degree or existence of housing portability counseling among the suburban housing authorities.

Output indicators are changes in the amount and location of portable movers. Unfortunately, data are not maintained from year to year in a format that enables a researcher to track time series changes in certificates originating in housing authorities or state agencies. However, it is possible to look at changes since 1992 in the Hartford Special Mobility Program. By utilizing the data gathered by Donovan (1992), this study analyzes the differences in amount and location in the Hartford Special Mobility Program by census tract from 1992 to 1996 . In addition to the Mobility Program, the report provides maps of all other current tenant-based units in the Capitol Region. These maps allow the researcher to target areas of concentration and opportunity. Finally, an analysis of the status quo is made including a comparison of the location of portable moves with those certificates originated and used in town and with state administered rental certificates. This will show if there is any distinction among the locations by type of certificate. 
The destination model

A picture of the tenant-based assistance model is presented below.

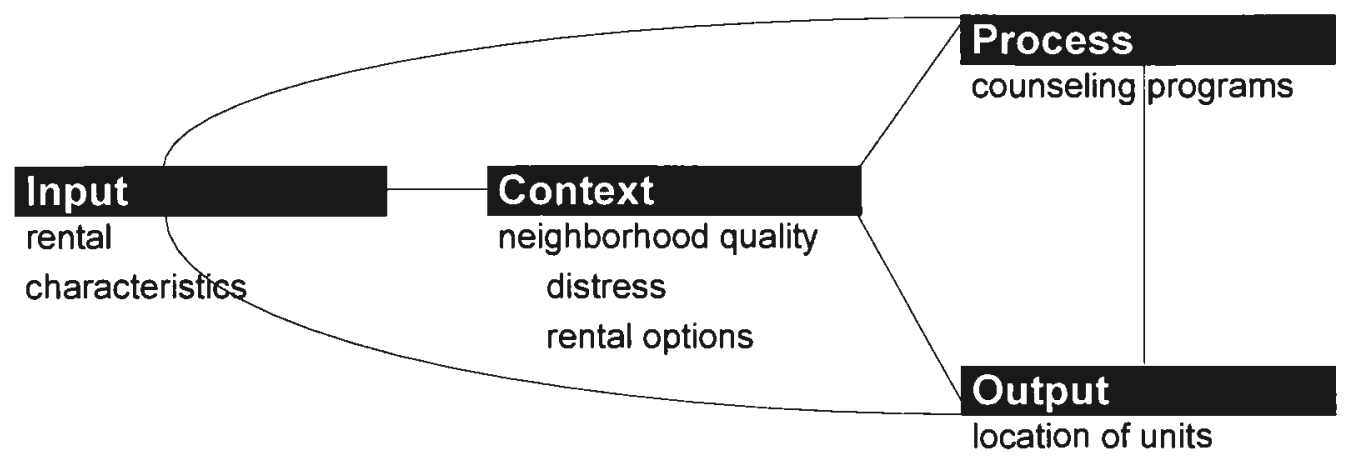

Although this report relies on 1990 census data, it is commonly accepted throughout the Capitol Region that the context has changed since then. Due to the economic downturn of the early 1990 s, local policy makers perceive that more rental property is available now than in 1989. Landowners, anxious to rent, should be more amenable to tenants on assistance when vacancies are high. If vacancies are up, then this change it would impact the model. The change in context would affect inputs, by increasing availability, the process by creating more options for the counseling programs, and of course the outputs, location.

\section{Locating tenant-based assistance}

The study uses ArcView 2.1, a geographic information system, to map the location of all tenant-based units in the Capitol Region by census tract. The first step was to get the streets, tract lines, and town boundaries for the Capitol Region into the mapping program. Next, the author requested data from the various 
housing authorities in a form that included street addresses. After creating a data base for each town and program, the data were geocoded to the streets of the region and overlaid by the tract and town boundaries. Next the results were analyzed. Some estimation of address location was necessary because of mismatched data from housing authorities and the 1994 TIGER files. In addition, the street database lacked a few streets, either because the streets were too new or for other unknown reasons. Overall, it was necessary to estimate between five and ten percent of the address points.

There are several caveats to mapping these units. The first is that tenant assistance is a dynamic system. The mapped portrayal is a snapshot of units that potentially change every day. However, although always in flux, with funding stagnant (or reducing as in the case of the state Rental Assistance Program [RAP]) the overall number of certificates has not changing substantially over the last two years. Hartford accounts for 871 units of the 923-unit difference between the two years. Most of the increase in Hartford's certificates comes from a special allotment the City received for the Charter Oak project. Other than two other footnoted comments, there is very little change from 1995 to 1996 (Table 6).

Second, mapping portable certificates is not exact. As noted earlier, the two state programs (RAP and state Section 8) do not keep data on certificates used for moving from one town to another. While it can be assumed that at least some of these households used the certificates to move between the towns, they cannot be so designated. Administrators also have the option to "swap" or 
Table 6 1995/1996 Regional Tenant Assistance

\begin{tabular}{|c|c|c|c|}
\hline \multirow{2}{*}{ Municipalities } & \multicolumn{3}{|c|}{ TotarRActhuse in Town } \\
\hline & 1995 & 1996 & Difference \\
\hline Andover & 3 & 2 & -1 \\
\hline Avon & 6 & 2 & -4 \\
\hline Bloomfield & 71 & 75 & 4 \\
\hline Bolton & 2 & 1 & -1 \\
\hline Canton & 7 & 19 & 12 \\
\hline East Granby & 0 & 0 & 0 \\
\hline East Hartford & 616 & 616 & 0 \\
\hline East Windsor & 14 & 16 & 2 \\
\hline Ellington & 5 & 5 & 0 \\
\hline Enfield & 190 & 197 & 7 \\
\hline Farmington & 93 & 88 & -5 \\
\hline Glastonbury & 51 & 37 & -14 \\
\hline Granby & 2 & 0 & -2 \\
\hline Hartford & 3,299 & 4,170 & 871 \\
\hline Hebron & 3 & 3 & 0 \\
\hline Manchester & 522 & 557 & 35 \\
\hline Marlborough & 2 & 2 & 0 \\
\hline Newington & 32 & 38 & 6 \\
\hline Rocky Hill & 4 & 2 & -2 \\
\hline Simsbury & 0 & 0 & 0 \\
\hline Somers & 2 & 4 & 2 \\
\hline South Windsor & 24 & 21 & -3 \\
\hline Suffield & 1 & 2 & 1 \\
\hline Tolland & 1 & 1 & 0 \\
\hline Vernon $^{c}$ & 420 & 321 & -99 \\
\hline West Hartford ${ }^{b}$ & 427 & 548 & 121 \\
\hline Wethersfield & 67 & 74 & 7 \\
\hline Windsor $^{d}$ & 175 & 173 & $\overline{-2}$ \\
\hline Windsor Locks & 89 & 77 & -12 \\
\hline Total & 6,128 & 7,051 & 923 \\
\hline
\end{tabular}

Notes: a RAC $=$ Rental Assistance Certificates and includes Section 8 vouchers, certificates, and State RAP

b Hartford and West Hartford received additional certificate allotments for special programs.

C The disparity in Vernon reflects an over counting in 1995 that was corrected in 1996.

d Windsor Locks total estimated due to unavailability of 1996 town data.

Source: The Housing Authorities in Canton, East Hartford, Enfield, Farmington, Glastonbury, Hartford, Manchester, Vernon, West Hartford, Windsor Locks, and Imagineers, Hartconn, and Community Renewal Team (CRT), Spring 1996. 
"absorb" certificates; when two towns have clients that want to move to the other town, to ease bureaucratic red tape, these certificates are simply swapped. With "absorption", a town makes a decision to take on the full responsibility of a certificate. In both cases, the client moved from one town to another but in neither case are records kept that allow designation as a portable move. Finally, obtaining an exact count is complicated by the way that clients use the system. Housing lists often close because all available certificates are in use, encouraging people to shop around and get on as many lists as possible. If their name comes up in another town, they may move without any record that it was an inter-municipal move. Because of these limitations, this study will have two layers of data. The first consists of those moves that can be accurately accounted as a mobility/portability move. The second is all other tenant-assisted housing. The two measures used in the mapping analysis are described below.

\begin{tabular}{llll} 
Concept & Measure & Source & Assumptions \\
\hline $\begin{array}{l}\text { Location of tenant- } \\
\text { based assistance }\end{array}$ & $\begin{array}{l}\text { Hartford Special } \\
\text { Mobility Program; } \\
\text { Town-to-town } \\
\text { portability }\end{array}$ & $\begin{array}{l}\text { 1992 Mobility: } \\
\text { Donovan } \\
1996 \text { mobility and } \\
\text { portability: Imagineers } \\
\text { and respective town } \\
\text { HAs }\end{array}$ & $\begin{array}{l}\text { Although all moves not } \\
\text { known, data serves to } \\
\text { illustrate primary } \\
\text { destinations }\end{array}$ \\
$\begin{array}{l}\text { Location of tenant- } \\
\text { based assistance }\end{array}$ & $\begin{array}{l}\text { All Section } 8 \text { and RAP } \\
\text { tenant-based } \\
\text { certificates }\end{array}$ & $\begin{array}{l}\text { Imagineers, CRT, } \\
\text { Hartconn, respective } \\
\text { town HAs }\end{array}$ & $\begin{array}{l}\text { Although a dynamic } \\
\text { system, the snapshot } \\
\text { does give outcomes }\end{array}$
\end{tabular}

\section{Social indicators}

This report called for two sets of indicators. One compares the "before" and "after" locations of movers. Another directs plans for deconcentrating tenantbased housing assistance in the region. Below is a discussion of the indicator specifications used in this report. 
Neighborhood distress

This analysis bases the statistics chosen for the indicator of neighborhood distress on an article by Kasarda (1993). His review of various measures of neighborhood distress are used to determine which census data to use. One statistic, poverty level, is utilized as a stand-alone statistic with the 1990 data for two reasons. First, several suburban elected officials have made statements that portable certificate holders are moving "from one pocket of poverty to another." The map of poverty tracts is a response to this charge. Unfortunately, comparable household poverty for 1980 was unavailable in the census, therefore change from 1980 to 1990 cannot be mapped. Second, Kasarda makes an important distinction between poverty tracts (with at least 20 percent of residents falling below the poverty level) and extreme poverty tracts (in which at least 40 percent are below poverty) (1993: 255).

In developing the combination distress indicator, Kasarda notes that a distressed neighborhood is one in which the tract simultaneously falls at least one standard deviation above the regional mean on the following measures: poverty, unemployment, female-headed families, public assistance. A severely distressed neighborhood is one for which the above is true and is also greater than one standard deviation on teenage school dropout rates. Teenage dropout rate is the distinguishing measure because completing high school is key for future economic success, especially in this technological economy (Kasarda, 1993: 257). In addition, it is also not highly correlated with the other four measures (correlation 
range from .46 to .59 ) suggesting that this statistic is measuring additional neighborhood effects not captured by the combined factors (Appendix 1).

One standard deviation from both sides of the mean is statistically likely to include approximately 65 percent of the population. This leaves 17.5 percent on either end of the normal curve. Therefore, it can be assumed that the bottom or top 20 percent of the population falls either more than one standard deviation from the mean or very close to that. The study utilizes this latter statistical conformity, rather than one standard deviation, to identify distressed tracts. After first ranking the tracts, those that simultaneously fell in the bottom 20 percent of the all tract rankings on each of the specific measures are classified as distressed, or as severely distressed when teenage dropout is added to the equation. By using 20 percent rather than the more specific 17.5 percent, the measure captures borderline tracts as well.

One note in regard to comparisons between 1980 and 1990. The distressed and severely distressed calculations for 1980 include all of the above statistics except households in poverty. As previously noted, these data were not available in comparable form in 1980. However, a correlation table of all the measures in 1990, including poverty, was run and determined that, with the exception of teenage dropouts, the correlation rating ranged from .81 to .97 for all measures. With this high degree of correlation, the author is confident that the other variables serve as alternate proxies for poverty in 1980 . The measures are described below. 


\begin{tabular}{|c|c|c|c|}
\hline Concept & Measure & Source & Assumptions \\
\hline Neighborhood distress & $\begin{array}{l}\text { Poverty: All } \\
\text { households below } \\
\text { federal poverty line }\end{array}$ & $\begin{array}{l}\text { 1990: U.S. Census, } \\
\text { Summary Tape File } \\
\text { (STF)3, Table } 127\end{array}$ & $\begin{array}{l}\text { Bottom } 20 \% \text { indicates } \\
\text { distress; greater than } \\
20 \% \text { defines a poverty } \\
\text { tract; more than } 40 \% \text { a } \\
\text { severe poverty tract }\end{array}$ \\
\hline Neighborhood distress & $\begin{array}{l}\text { Female head of } \\
\text { household }\end{array}$ & $\begin{array}{l}\text { 1990: U.S. Census, } \\
\text { STF1, Table P16 } \\
\text { 1980: U.S. Census } \\
\text { PHC80-2-181, Table } \\
\text { P1 }\end{array}$ & $\begin{array}{l}\text { Bottom } 20 \% \text { indicates } \\
\text { distress }\end{array}$ \\
\hline Neighborhood distress & Public assistance & $\begin{array}{l}\text { 1990: U.S. Census, } \\
\text { STF3, Table P95 } \\
\text { 1980: U.S. Census, } \\
\text { PHC80-2-181, Table } \\
\text { P11 }\end{array}$ & $\begin{array}{l}\text { Bottom } 20 \% \text { indicates } \\
\text { distress }\end{array}$ \\
\hline Neighborhood distress & $\begin{array}{l}\text { Unemployment: } \\
\text { Unemployed labor } \\
\text { force over } 16\end{array}$ & $\begin{array}{l}\text { 1990: U.S. Census, } \\
\text { STF3, Table P70 } \\
\text { 1980: U.S. Census, } \\
\text { PHC80-2-181, Table } \\
\text { P10 }\end{array}$ & $\begin{array}{l}\text { Bottom } 20 \% \text { indicates } \\
\text { distress }\end{array}$ \\
\hline Neighborhood distress & $\begin{array}{l}\text { Teenage school } \\
\text { dropout: Population } \\
16-18 \text { not in school } \\
\text { and without HS degree }\end{array}$ & $\begin{array}{l}\text { 1990: U.S. Census, } \\
\text { STF3, Table P61 } \\
\text { 1980: U.S. Census, } \\
\text { PHC80-2-181, Table } \\
\text { P10 }\end{array}$ & $\begin{array}{l}\text { Bottom } 20 \% \text { indicates } \\
\text { severe distress }\end{array}$ \\
\hline
\end{tabular}

Rental desirability

The statistics used to mark census tracts by their rental desirability were chosen very simply. The author examined available census tables in 1990 from Summary Tape File 1 (STF1) and Summary Tape File 3 (STF3) for tables relevant to the rental property market and selected several options. Then the tables for which comparable data were available in 1980 were chosen. The statistics are, as noted previously and presented below, amount of rental property, amount of vacant rental property, affordability, and presence of school age children. 


\begin{tabular}{|c|c|c|c|}
\hline Concept & Measure & Source & Assumptions \\
\hline Rental desirability & $\begin{array}{l}\text { Amount of rental } \\
\text { property: all renter } \\
\text { occupied and vacant } \\
\text { for rent units }\end{array}$ & $\begin{array}{l}\text { 1990: U.S. Census, } \\
\text { STF1, Table H3, H5 } \\
\text { 1980: U.S. Census } \\
\text { PHC80-2-181, Table } \\
\text { H1 }\end{array}$ & $\begin{array}{l}\text { Top } 40 \% \text { indicates } \\
\text { desirability. }\end{array}$ \\
\hline Rental desirability & $\begin{array}{l}\text { Vacant rental property: } \\
\text { all vacant for rent units }\end{array}$ & $\begin{array}{l}\text { 1990: U.S. Census, } \\
\text { STF1, Table H3, H5 } \\
\text { 1980: U.S. Census } \\
\text { PHC80-2-181, Table } \\
\text { H1 }\end{array}$ & $\begin{array}{l}\text { Top } 40 \% \text { indicates } \\
\text { desirability. A higher } \\
\text { the vacancy rate } \\
\text { increases willingness } \\
\text { to rent to Section } 8 \\
\text { tenants. }\end{array}$ \\
\hline Rental desirability & $\begin{array}{l}\text { Rental Affordability: all } \\
\text { rental units affordable } \\
\text { to those at } 50 \% \text { of } \\
\text { regional income. }\end{array}$ & $\begin{array}{l}\text { 1990: U.S. Census, } \\
\text { STF3, Table H43 } \\
\text { 1980: U.S. Census } \\
\text { PHC80-2-181, Table } \\
\text { H8 }\end{array}$ & $\begin{array}{l}\text { Top } 40 \% \text { indicates } \\
\text { desirability. }\end{array}$ \\
\hline Rental desirability & $\begin{array}{l}\text { Presence of school } \\
\text { age children }\end{array}$ & $\begin{array}{l}\text { 1990: U.S. Census, } \\
\text { STF1, Table P18 } \\
\text { 1980: U.S. Census } \\
\text { PHC80-2-181, Table } \\
\text { P1 }\end{array}$ & $\begin{array}{l}\text { Top } 40 \% \text { indicates } \\
\text { desirability. } \\
\text { Neighborhoods with } \\
\text { children are more } \\
\text { attractive to movers } \\
\text { with children. }\end{array}$ \\
\hline
\end{tabular}

The rationales for rental property and affordability are apparent. The more and the cheaper the units, the more that are available to a low income population. Since a certificate program relies on the private sector to provide units, vacancy is included to account for the impacts of the market on availability. In a tight market, landowners can be more selective in their choice of tenants; conversely, in a loose market, tenants on government assistance have more options. The final statistic, school-age children, was included to provide a more qualitative aspect to neighborhoods. People move into an area and because the price is right but also

\footnotetext{
${ }^{7}$ Calculation procedure: Affordability is commonly considered to be when housing costs are no more than $30 \%$ of income. The median household income for the Capitol Region in 1990 was $\$ 42,077$. Therefore, the calculation is: $\left(\$ 42,077^{\star} 5\right) / 12=\$ 1753$ monthly income at 50 percent of median. $\$ 17538.3=\$ 525$ affordable rent per month for those at 50 percent of median income.
} 
because it "feels" right. The measurement of school-age children tries to get at some of these more intangible aspects. Many, but not all, of those moving with certificates are households with children. ${ }^{8}$ The author theorizes that neighborhoods with children would be more hospitable, ease assimilation into the new environment, and provide a neighborhood quality sought by movers.

In the calculations a modified version of the formula used for distress was applied. With distress, the identity sought was of the extreme, the most problematic tracts. With desirability, leniency was worthwhile. As there are numerous ways that public policy, through zoning and funding, can direct rental property availability, the author surmised that a tract in which the statistics were above the mean in any of the rental characteristics offered potential for expanding opportunities. Furthermore, the number of households that rely on rental assistance is such a small percentage of the regional or any suburban town household total that a tract with even a few additional units or knowledge of existing rental potential could help deconcentrate other tracts. Therefore, the top 40 percent was chosen as the cutoff point for identifying a rent-positive characteristic. If the tract was above the mean on three out of the four statistics, the author designated it a high desirability tract. Of course, many distressed tracts were highly rent-oriented as well. As there are obvious incongruities with naming a distressed tract as also desirable, those tracts that had previously been typed as a distressed tract were automatically excluded from further assessment.

\footnotetext{
${ }^{8}$ For example, over 90 percent of the Hartford Special Mobility participants are families with children.
} 


\section{Limitations}

There are several limitations that must be noted before moving on to the results. The first concerns the ramifications of direct and indirect measures. Second are the limitations to using Census data and finally some comments on other choices made for this study.

\section{Use of social indicators}

A direct indicator is a measure of the specific variable under examination. This study uses the number of mobility certificates as a direct, output indicator. An indirect indicator is used as a surrogate for a variable in which experience or theory hypothesizes a relationship between the indicator and the variable (Rossi and Gilmartin, 1980). For instance, in this report, the percentage of the population on public assistance, unemployed, with a female head of household, or teen-age dropouts are all indirect measures of neighborhood distress.

Indirect measures pose two problems. First, the indirect measure can become mistakenly used as the policy objective. When this happens, the underlying problems are overlooked because policy emphasis is place on the measure and not the problem.

Second, use of indirect measures can re-enforce beliefs that there is an inherent deficit in the person or household who holds that particular characteristic. There is nothing innately wrong with female-headed or poor households. Femaleheaded households were studied as a way to identify aspects of neighborhood distress: barriers to housing options and the potential for insufficient child 
supervision. Data on single-parent households were preferred but were not available for this statistic in similar forms in both 1980 and 1990 . Single-parent households may be symptoms of problematic neighborhoods because there are fewer adults or adults with severe time constraints providing supervision for children. In female-headed households, the problem is not that women are the household head but that they may have more responsibilities with fewer resources than a two-parent household or even a male-headed household with children. Furthermore, women, in disproportionate numbers to men, face challenges in family care, domestic violence, and pay equity and other forms of job discrimination that create barriers to escaping poverty (Bergmann, 1986; Blau and Ferber, 1986; French, 1992; hooks, 1984; Mulroy, 1988; Sidel, 1986; Smith, 1983; Sprague, 1991). With indirect measures there is a danger that underlying problems are overlooked if policy is side-tracked by the indicator.

Finally, whether indirect or direct, indicators reflect a normative bias. Again both poor and female-headed households are used as measures because there exists a normative bias for a particular household structure, often, in the United States, a preference for a middle-class, two-parent, heterosexual household structure. This preference fails to account for the different customs that distinct cultures utilize with household structure (Stack, 1974). Within diverse cultures, and often because of extended and strong community connections, single-parent households make healthy household structures; they are not alternatives to a norm but one part of the continuum of living options. 


\section{Census data notations}

For the purposes of this research, tract level data serves fairly well but it does have some limitations. When looking for concentration on a region-wide basis, census tracts are an appropriate level of measurement. The spatial size is suitable and the data are available both in printed and CD-ROM form in detailed tables representing 100 percent-count and sample-count data with comparable information for 1980 and 1990.

However, for concentration within towns, the block level would provide a more specific area for analysis. The block is a subdivision of census tracts and the smallest unit tabulated within census material. Unfortunately, because of concerns about confidentiality and sampling error, data for these small areas are not available in the same detail as tract-level data (Myers, 1992: 70). Block data are not released in printed form at all, and in computerized form only for questions derived from the 100-count questionnaire. Since half of the tables selected for this document come from the sample count data, area specificity provided by block data was foregone in favor of a richer scope of information. The details provided from sample data are integral to tenant-based assistance programs both for describing the destination tracts and identifying under-utilized tracts.

Two other details about the tracts need to be noted. First, the region had twelve fewer tracts in 1980 . For the 1990 Census, several towns divided tracts, and Hartford changed some tract boundaries but kept the same overall number of 
tracts. ${ }^{9}$ For tracts that split, the 1990 data for these split tracts were combined when compared with 1980 data which further reduces specificity. Second, the Capitol Region contains five mostly or entirely institutional tracts. These are census tracts wherein almost the entire population resides either in a correctional or long-term health care facility. ${ }^{10}$ They are therefore exempt from all tract analyses and not applicable to certificate programs.

Finally, census data has the advantage of being readily available whereas measurements of change between censuses are difficult, especially at the tract level. A number of ways to measure change within selected towns and tracts between 1990 and 1996 were considered. However, the resources to undertake that analysis were not available; it is certainly an area for future study.

\section{Other considerations}

In writing this report, the author was concerned about the choice to focus on tenant-based rental assistance in general and portable certificates in particular rather than on other, often more acceptable, forms of housing assistance such as mortgage interest tax credit. On balance the decision to focus on rental assistance was appropriate considering the high level of concern focused on these programs (Swift and Dempsey, 1995), ongoing efforts in Congress to eliminate project-based rental assistance in favor of tenant-based programs (Polikoff 1995), and that fact that new rental assistance certificates were the second largest source of all new

\footnotetext{
${ }^{9}$ The towns which had boundary changes are: Avon, Canton, Farmington, Granby, Manchester, Newington, Rocky Hill, Simsbury, Somers, and Suffield.

${ }^{10}$ Tract 4801 in Enfield; 4902 in Rocky Hill; 5006 and 5007 in Hartford; and 5381 in Somers
} 
affordable opportunities created in the region over the last five years (CRCOG, September 1995: 4).

However, even in the number two position, they still only comprised 21 percent of new affordable housing in the region. Furthermore, identifiable incoming portable certificates make up less than 10 percent of all regional certificates (Table 7). A concern is that studying this politically volatile topic will fuel a backlash against an important, but unpopular, program. The emphasis needs to be on addressing community concerns so the program can be improved, not further limited. This is the purpose of the following chapters. 


\section{CHAPTER FOUR: SOCIAL INDICATOR ASSESSMENT}

This chapter utilizes census data to describe the characteristics of census tracts in the Capitol Region that are of concern to regional housing policy-makers and relevant to a rental assistance program. The first section presents a literature review of social indicators. The next gives the context for the discussion of specific indicators. The third section states the results of the indicators and statistics. After identifying areas of distress and opportunity, the discussion of each indicator concludes with an analysis of change in the region from 1980 to 1990 . By the end of this chapter, research question three (whether movers are better off before or after the move) will be answered and initial responses to question four (identifying new opportunities) begun.

\section{Social indicator review}

\section{Background}

Interest in social indicators emerged in the 1960s with frequent proposals for a system of social indicators much like the series of economic indicators already so heavily used by government. Land and Spilerman described social indicators as "indices of various social conditions within particular communities or societies" and "measurements of the contexts of the social life of members of a society" (1975: 1).

However, this was not the first attempt to find ways to track social change. Earlier efforts in social measurements can be traced to the 1920 s and the research 
done by William Ogburn and his colleagues for President Hoover's Research Committee on Social Trends (Rossi and Gilmartin, 1980). Despite their 1933 publication of Recent Social Trends in the United States, interest in social measures waned until the social upheavals of the 1960s. With the civil rights, antiwar, women's and lesbian/gay movements along with the federally-led War on Poverty, there was an heightened awareness of the need to track the impact of both governmental policies and demographic shifts (Rossi and Gilmartin, 1980: 2).

One of the initial signs of a resurgence was the work Social Indicators (1966) by Raymond Bauer. This book coined the term "social indicators" and was quickly followed by Senator Mondale's 1967 legislative proposal to establish a Council of Social Advisors analogous to the Council of Economic Advisors. Unfortunately, the bill died in committee. Another instrumental organization was the Russell Sage Foundation, which funded and published several influential documents in the 1970s.

Since the 1970s, work on social indicators has continued to evolve. The academic journal Social Indicator Research has published continuously since 1974. SINET, the Social Indicators Network News, edited by Abbot L. Ferriss, is a quarterly newsletter providing a review of current literature and events. The United Nations and the Organization for Economic Cooperation and Development are two groups that have participated in much of the social indicator research with a variety of committees devoted to measuring social status (Michalos, 1992). 


\section{Definition and description}

Describing the actual definition of an indicator is not as simple as relaying the historic record as various researchers have defined social indicators in different ways. Still, there is some common agreement along three general purposes for indicators.

The first is a social policy rationale. Indicators can: a) evaluate government programs, b) establish a system of social accounts similar to leading economic indices, and c) establish and set governmental goals and policies (Land and Spilerman, 1975: 5). The second area of agreement is that indicators are useful for tracking social change. Unlike the social policy focus of public programs, the premise here is that society is changing rapidly and that knowledge of the rate and direction of change is crucial (Land and Spilerman, 1975: 12). Third, researchers agree on the need for a mechanism for social reporting both of the status quo and predictions of the future (Land and Spilerman, 1975: 14). This report relies on all three purposes for the associated indicators. The end purpose is to inform and improve public policies regarding tenant-based assistance. In order to do so, knowledge is needed of the current locations of the tenant-based units and of the social changes occurring both in terms of the population and the rental situation.

Researchers adhere to two key characteristics of social indicators: 1) they are organized in a time series to allow comparison across time and 2) they are disaggregated or aggregated by relevant attributes (Land and Spilerman, 1975; Rossi and Gilmartin, 1980). This report uses 1980 and 1990 census data as well as 1992 and 1996 mobility data for comparisons across time. In addition, two sets 
of indices of indicators, one on neighborhood distress and the other on rental desirability, each composed of four to five different statistics, have been developed.

As long as these first two characteristics (time series and aggregative) are met, social indicators come in a variety of types. An indicator can be descriptive or analytic (outside or part of a theoretical framework); input or output (the catalyst into or result of a social policy or change); context or process (measuring the environmental conditions or the policy procedures); or direct or indirect (Rossi and Gilmartin, 1980).

\section{Concerns}

The use of social indicators is not without concerns. Michalos (1992: 9-10) writes that social indicators and reports can be used or abused in the following ways:

1) Give visibility to social problems, but possibly to create them by focusing attention on them, or hide some in the interest of emphasizing others.

2) Evaluate current public policy and programs, but perhaps make slanted evaluations because the statistics routinely collected may not allow decisionmakers to control for important contextual variables when causality is at question.

3) Provide a common framework for thinking about society, but by its common acceptance, eliminate different points of view from the analysis.

4) Balance assessments of social conditions against economic assessments, but possibly distorting evaluations by assuming that a monetary base makes the best equalizer and tool for comparability. 
The newer literature on social indicators addresses some of Michalos' criticism. Hazel Henderson is one of the current generation of critics of governmental reliance on economic statistics as sole indicator of quality of life. Henderson believes that the debate is finally shifting from how to measure to what to measure (1995: 150). She advocates that in order to know what to measure, the goals first must be clear and agreed upon whether of public policy-makers or of members of the general public. With clear, explicit goals, the normative leanings are more likely to be overt rather than covert and can therefore be either challenged or accepted.

Even identifiable goals are not enough to address all measurement issues. For example, if the goal is to increase productive output, then measurements of sales of products and service seems to be an accurate measure. But even that becomes questionable when the discussion comes around to what is productive work. Caring for the young, elderly, and ill; maintenance of the home; volunteer service; food production for home consumption: all of these are productive, yet unmeasured by standard economic statistics.

And while Henderson's focus is predominantly on national and international comparisons, she does discuss local-level indicators as well. The City of Jacksonville, Florida has for several years collected a list of Quality Indicators for Progress that incorporates the economy with public safety, mobility, government, social environment, culture, health, and more (Henderson, 1995: 172). The City's intention is to find an index that combines qualitative and quantitative values of life. 
Finally, Henderson addresses the weaknesses in measurement techniques that try to modify economic terms to use as a measure of social desires. She suggests that questions that ask how much one would pay to preserve a building or open space or public school ignores "prior distribution of wealth and power in society" as well as who pays and who profits (Henderson, 1995: 185). All this social measurement work reflects endeavors to recognize that quality of life cannot be bought but is developed through tangible and intangible combinations of private and public contributions. For instance, portable, tenant-based assistance combines the private market, individual housing decisions, and public funding toward a goal of creating a higher quality of life both for the recipients and communities.

\section{Setting the Stage}

The collection of the census data preceded the bulk of the portability moves in the region. What this census examination gives is a picture of the region and ongoing changes, particularly in the tracts that are now the primary sites for tenantbased housing, both portable and in-town units. Again, the study only looks at geographic place elements rather than other components that impact living location choices. A survey conducted in Hartford in 1991 found that certificateholders move for many of the same reasons that most people do: for better schools, to live closer to friends and/or family, to get a job, to live in a better neighborhood (Donovan, 1993: 8). Furthermore, the impact of transportation, particularly public transit, and social services are other avenues for study. 
Nevertheless, place is where town planners can directly act to effect change.

Creating good, accessible, and diverse neighborhoods is an admirable goal. To make it happen, however, undue burdens and regionally shared responsibilities and costs need to be recognized.

The first part of this analysis, poverty tracts' location, focuses on the statistic and indicator more relevant to the Hartford Special Mobility Program than to other regional moves. The location of poverty tracts and the indicator of distressed neighborhoods responds to research question three: Are certificate/voucher holders moving to neighborhoods that were either pockets of poverty in 1990 or closer to poverty in 1990 than they had been in 1980 ? In other words, are participants in the Mobility Program better or worse off after their moves? However, the Mobility Program is not the sole source of certificate-based moves in the region. Anyone holding a certificate can use it to move to another town. The distinction, as noted in Chapter Two, is that the administrators of the Mobility Program negotiate directly with property-owners in other towns, while other portable moves are administered through local or state housing authorities. The table below shows the number of identified certificate moves in the region.

Table 7 Capitol Region Portability

\begin{tabular}{|c|c|c|c|c|c|c|}
\hline Municipalities & $\begin{array}{l}\text { Total in } \\
\text { Use in } \\
\text { Town }\end{array}$ & $\begin{array}{l}\text { Town } \\
\text { Regional } \\
\text { Incoming }\end{array}$ & $\begin{array}{l}\text { Town Out of } \\
\text { Reg. Incoming }\end{array}$ & $\begin{array}{l}\text { Hartford } \\
\text { Mobility }\end{array}$ & $\begin{array}{c}\text { Total } \\
\text { In }\end{array}$ & $\begin{array}{c}\text { Percent } \\
\text { Incoming }\end{array}$ \\
\hline Andover & 2 & & & 0 & 0 & \\
\hline Avon & 2 & & & 0 & 0 & \\
\hline Bloomfield & 75 & & & 27 & 27 & 36.0 \\
\hline Bolton & 1 & & & 0 & 0 & \\
\hline Canton & 19 & & & 0 & 0 & \\
\hline East Granby & 0 & & & 0 & 0 & \\
\hline
\end{tabular}


Table 7, Con't.

\begin{tabular}{|c|c|c|c|c|c|c|}
\hline Municipalities & $\begin{array}{c}\text { Total In } \\
\text { Use } \\
\text { In Town }\end{array}$ & $\begin{array}{c}\text { Town } \\
\text { Regional } \\
\text { Incoming }\end{array}$ & $\begin{array}{l}\text { Town Out of } \\
\text { Reg. Incoming }\end{array}$ & $\begin{array}{l}\text { Hartford } \\
\text { Mobility }\end{array}$ & $\begin{array}{l}\text { Total } \\
\text { In }\end{array}$ & $\begin{array}{c}\text { Percent } \\
\text { Incoming }\end{array}$ \\
\hline East Hartford & 616 & 38 & 15 & 152 & 205 & 33.3 \\
\hline East Windsor & 16 & & & 0 & 0 & \\
\hline Ellington & 5 & & & 1 & 1 & \\
\hline Enfield $^{\mathrm{a}}$ & 197 & 18 & 10 & 8 & 36 & 18.3 \\
\hline Farmington & 88 & 2 & 0 & 1 & 3 & 3.4 \\
\hline Glastonbury & 37 & 1 & 0 & 4 & 5 & 13.5 \\
\hline Granby & 0 & & & 0 & 0 & \\
\hline Hartford & 4,170 & 42 & 35 & & 77 & 1.8 \\
\hline Hebron & 3 & & & 1 & 1 & \\
\hline Manchester & 557 & 35 & 7 & 85 & 127 & 22.8 \\
\hline Marlborough & 2 & & & 0 & 0 & \\
\hline Newington & 38 & 1 & 2 & 5 & 8 & 21.1 \\
\hline Rocky Hill & 2 & & & 0 & 0 & \\
\hline Simsbury & 0 & & & 0 & 0 & \\
\hline Somers & 4 & & & 0 & 0 & \\
\hline South Windsor & 21 & 1 & 0 & 2 & 3 & 14.3 \\
\hline Suffield & 2 & & & 0 & 0 & \\
\hline Tolland & 1 & & & 1 & 1 & \\
\hline Vernon $^{2}$ & 321 & & & 14 & & \\
\hline West Hartford & 548 & 28 & 7 & 50 & 85 & 15.5 \\
\hline Wethersfield & 74 & 2 & 1 & 22 & 25 & 33.8 \\
\hline Windsor $^{\mathrm{a}}$ & 173 & & & 24 & & \\
\hline Windsor Locks & 77 & 1 & 1 & 1 & 3 & 3.9 \\
\hline Total & 7,051 & 169 & 78 & 398 & 645 & 9.1 \\
\hline
\end{tabular}

Notes:

a Neither Vernon or Windsor provided information on incoming portable units.

Source:

Housing Authorities in respective towns and Imagineers for Hartford Special Mobility

Program, Spring 1996.

The total of all in-moving certificate moves in the region is 645 . The total of non-Mobility Program moves, whether from inside or outside of the region, equals 247. Seventy-seven of these moves are moves into Hartford, leaving a total of 170 to the other 28 towns of the Capitol Region. Of this number, approximately 15 are also from Hartford through the Hartford Housing Authority, rather than the 
Mobility Program, yielding a total of about 155 non-Hartford based portable moves (meaning moves between towns other than Hartford) or about 25 percent of all moves in the region. It is a significant portion, although not a majority,. Hartford is the source of 64 percent of all identified regional moves. The remainder includes out-of-region sources and the moves into Hartford both from inside and outside of the region.

\section{Outcomes of the Hartford Special Mobility program}

Fair housing advocates designed the Hartford Special Mobility Program to expand the housing options of Hartford low-income residents. The indications are that it has been successful in doing just that. It is true that currently less than 11 percent of the Hartford's tenant-based assistance population participate in the Special Mobility Program. ${ }^{11}$ However, the number of Capitol Region residents using this program has exactly doubled since 1992. In that year there were 199 households from the Hartford program in Capitol Region suburban towns; now there are 398. Most of the increase has been through more residents moving to the same census tracts as 1992 destination tracts. Still, there are now six towns with one or two households from this program that had zero participants just four years ago (Table 8 ). In addition, there are five other towns that now have Mobility participants in tracts that had none in 1992 . These include the areas of western Farmington, Ellington, Hebron, Tolland, Enfield, Vernon, and northern Windsor and South Windsor. Both Enfield and Vernon are towns that have historically housed 
lower-income populations. The tenant-assisted units in the other towns, though few in number, suggest that opportunities exist for expansion into these less utilized towns. Not only are the number of destination towns increasing, but the number of tracts used within towns are slightly up as well.

Given this doubling, concern emanating from the destination towns is understandable. While the allotment of tenant-based certificates has been frozen in most towns, most towns are still encountering some change in the number of certificates

Table 8 Hartford Special Mobility Program: 1992 and 1996

\begin{tabular}{|c|c|c|c|}
\hline Municipalities & $\begin{array}{l}\text { L } 1992 \\
\text { Certificates }\end{array}$ & $\begin{array}{l}1996 \\
\text { Certificates }\end{array}$ & $\begin{array}{l}\text { Percent } \\
\text { Change }\end{array}$ \\
\hline Andover & 0 & 0 & \\
\hline Avon & 0 & 0 & \\
\hline Bloomfield & 12 & 27 & 125.0 \\
\hline Bolton & 0 & 0 & \\
\hline Canton & 0 & 0 & \\
\hline East Granby & 0 & 0 & \\
\hline East Hartford ${ }^{a}$ & 69 & 152 & 120.3 \\
\hline East Windsor & 0 & 0 & \\
\hline Ellington & 0 & 1 & \\
\hline Enfield $^{a}$ & 3 & 8 & 166.7 \\
\hline Farmington & 0 & 1 & \\
\hline Glastonbury $^{a}$ & 2 & 4 & 100.0 \\
\hline Granby & 0 & 0 & \\
\hline \multicolumn{4}{|l|}{ Hartford } \\
\hline Hebron & 0 & 1 & \\
\hline Manchester $^{2}$ & 41 & 85 & $\overline{107.3}$ \\
\hline Marlborough & 0 & 0 & \\
\hline Newington ${ }^{\mathrm{a}}$ & 2 & 5 & 150.0 \\
\hline Rocky Hill & 0 & 0 & \\
\hline Simsbury & 0 & 0 & \\
\hline Somers & 0 & 0 & \\
\hline
\end{tabular}

${ }^{11}$ A total of 540 of $4605 ; 540$ is the overall number provided by Imagineers, the administrators of the Mobility Program. 4695 includes the total originated and in use in Hartford (3225), RAP (291), State Section 8 (577), plus total outgoing minus swaps and absorptions (512). 
Table 8, Con't.

\begin{tabular}{lrrrr} 
Municipalities & $\begin{array}{r}1992 \\
\text { Certificates }\end{array}$ & $\begin{array}{c}1996 \\
\text { Certificates }\end{array}$ & $\begin{array}{r}\text { Percent } \\
\text { Change }\end{array}$ \\
\hline South Windsor & 0 & 2 & & \\
Suffield & 0 & 0 & \\
Tolland & 0 & 1 & 55.6 \\
\hline Vernon & 9 & 14 & 35.1 \\
West Hartford & 37 & 50 & 140.0 \\
Wethersfield & 14 & 22 & 100.0 \\
\hline Windsor & 10 & 24 & \\
Windsor Locks & 0 & 1 & \\
\hline Total & 199 & 398 & \\
Notes: & & & \\
a Indicates a town in which certificates went to more census & & \\
tracts than in 1992. & & & \\
b West Hartford does not participate in special aspects of & & \\
Mobility Program but still receives certificates through & & \\
Imagineers. & & & \\
Source: & & & \\
1992: Donovan & & & \\
1996: Imagineers & &
\end{tabular}

because of portability. With funding stagnant, it is the program area wherein much of the fluctuation will occur in the future. The Special Mobility Program is an indication, but not the sole source, of this growth.

Most of the towns that were on the receiving end in 1992 experienced a 100 percent increase in Mobility residents by 1996 (Table 8). The exceptions were West Hartford (35\% increase), Wethersfield (57\% increase), and Vernon (55\% increase). Of course, percentages can be misleading when the original number was small, such as in Newington. Still, the evidence suggests that most towns are growing proportionally according to their base number. The disproportionality in migration that occurred at the outset of the program accounts for the continuing wide spread of Mobility moves from town to town. 
The relatively small increase in West Hartford is unusual but so too is West Hartford's participation in the Mobility Program. Technically, the Mobility program is not active in West Hartford but instead performs as a traditional certificate portability program. It is the only town in the region to not follow the program's innovative precept of direct dealings between Imagineers, clients, and suburban property owners. In this town, Imagineers must go through West Hartford Housing Authority when Hartford residents desire to move to that town, a mechanism that does appear to inhibit the growth of the program in this town.

\section{Analysis}

\section{Poverty tracts}

So are these Hartford out-

migrators in better neighborhoods now?

All the measurement supports are

positive. First the location of the

poverty tracts throughout the region is

Poverty Tract
More than 20 percent of households
below the federally-defined poverty
level.
Severe Poverty Tract
More than 40 percent of households
below the federally-defined poverty
level.

examined (Figure 3). Using the breakdown offered by Kasarda (i.e., that a census tract with greater than 20 percent of households in poverty is a poverty tract; greater than 40 percent a severe poverty tract), all the poverty tracts are located within Hartford's borders (1992). Hartford has 13 tracts in each of the poverty and severe poverty categories. Of the 13 Hartford tracts in which 10 to 
20 percent of households are below poverty, four are close to the 20 percent point. This leaves only eight tracts in the 0 to 10 percent range. ${ }^{12}$

In sharp contrast is the remainder of the Capitol Region, where only two of the 144 tracts are even in the mid-poverty range. ${ }^{13}$ The two tracts in the $10-20$ percent classification are tract 5106 in East Hartford and tract 5302 in Vernon. In both these tracts the poverty rate is on the low side, with rates of 10.5 and 11.4 respectively.

\section{Neighborhood distress indicators}

Current status

For the index of neighborhood

distress, the same picture is drawn.

Based on Kasarda's analysis, a tract

is classified as distressed when it is in

the bottom 20 percent of all tracts in

the region simultaneously on the

following four statistics: poverty,

Distressed Tract

Ranked in the bottom 20 percent on 3

of the 4 distress statistics.

Poverty

Unemployment

Female Head of Household

Public Assistance

Severely Distressed Tract

Ranked in the bottom 20 percent on all the above plus teenage dropout.

female head of household, public assistance, and unemployment. A severely

distressed tract is in the bottom 20 percent on all the preceding, plus in percentage

of teenage dropouts. Here again, all distressed (6 tracts) and all severely

distressed tracks (18) as of 1990 were located in Hartford (Figure 4).

\footnotetext{
${ }^{12}$ Hartford has two institutional tracts to bring the total number of tracts to 49 .

${ }^{13}$ This includes three institutional tracts.
} 


\section{Figure 3 Poverty Tracts Capitol Region, 1990}

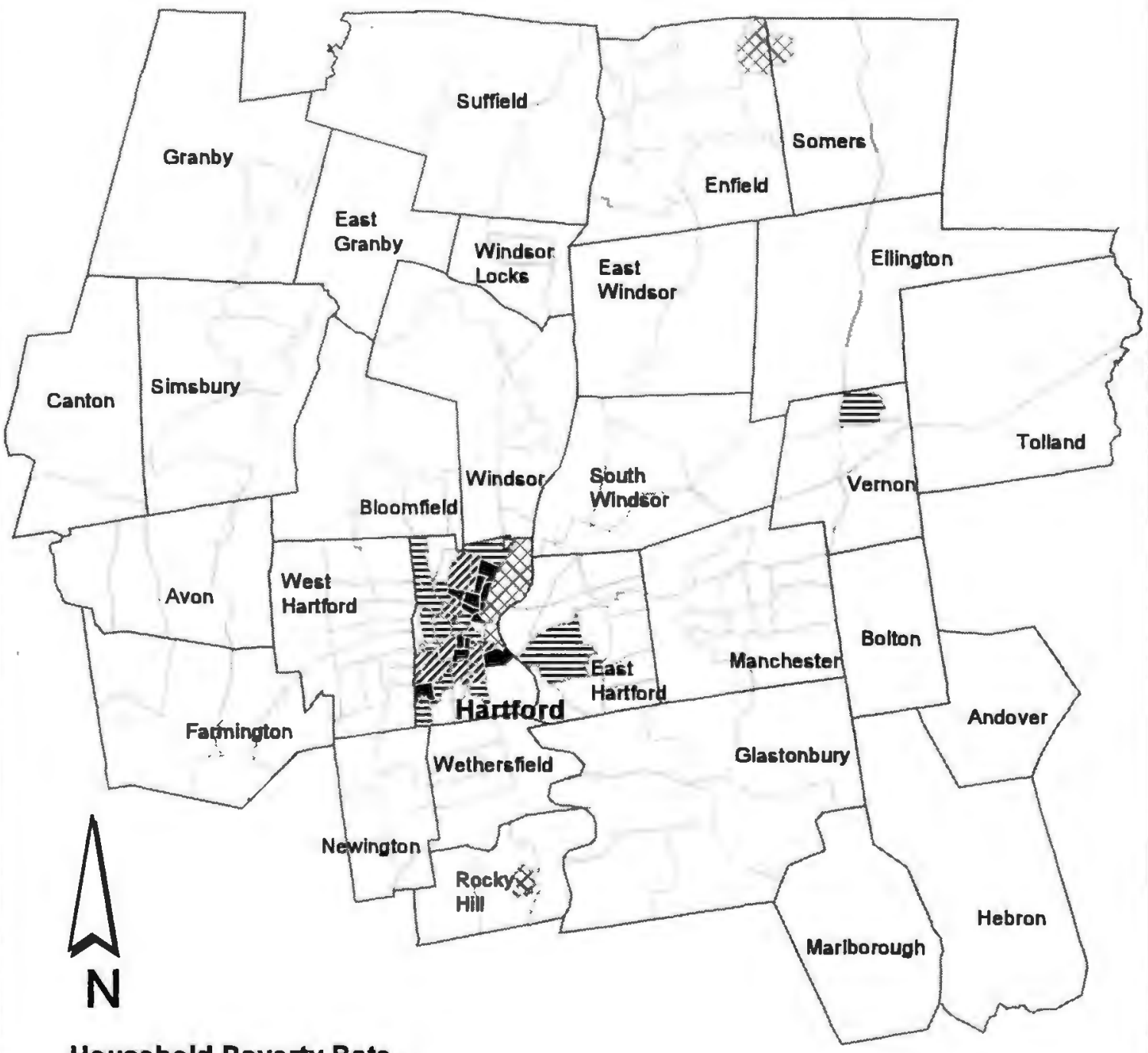

Household Poverty Rate

$0-10 \%$

$10-20 \%$

$20-40 \%$ (high poverty tract)

$40+\%$ (severe poverty tract)

$\$ 8$ Institutional Tracts

The percentage of all census tract households that are below the federally-defined poverty level.

Poverty rate not applicable

Source: 1990 U.S. Census, STF3,

0123456 Miles Table 127, extracted from CD-ROM by author. Boundaries from 1994 U.S. TIGER files. 


\section{Figure 4 Distressed Census Tracts Capitol Region, 1990}

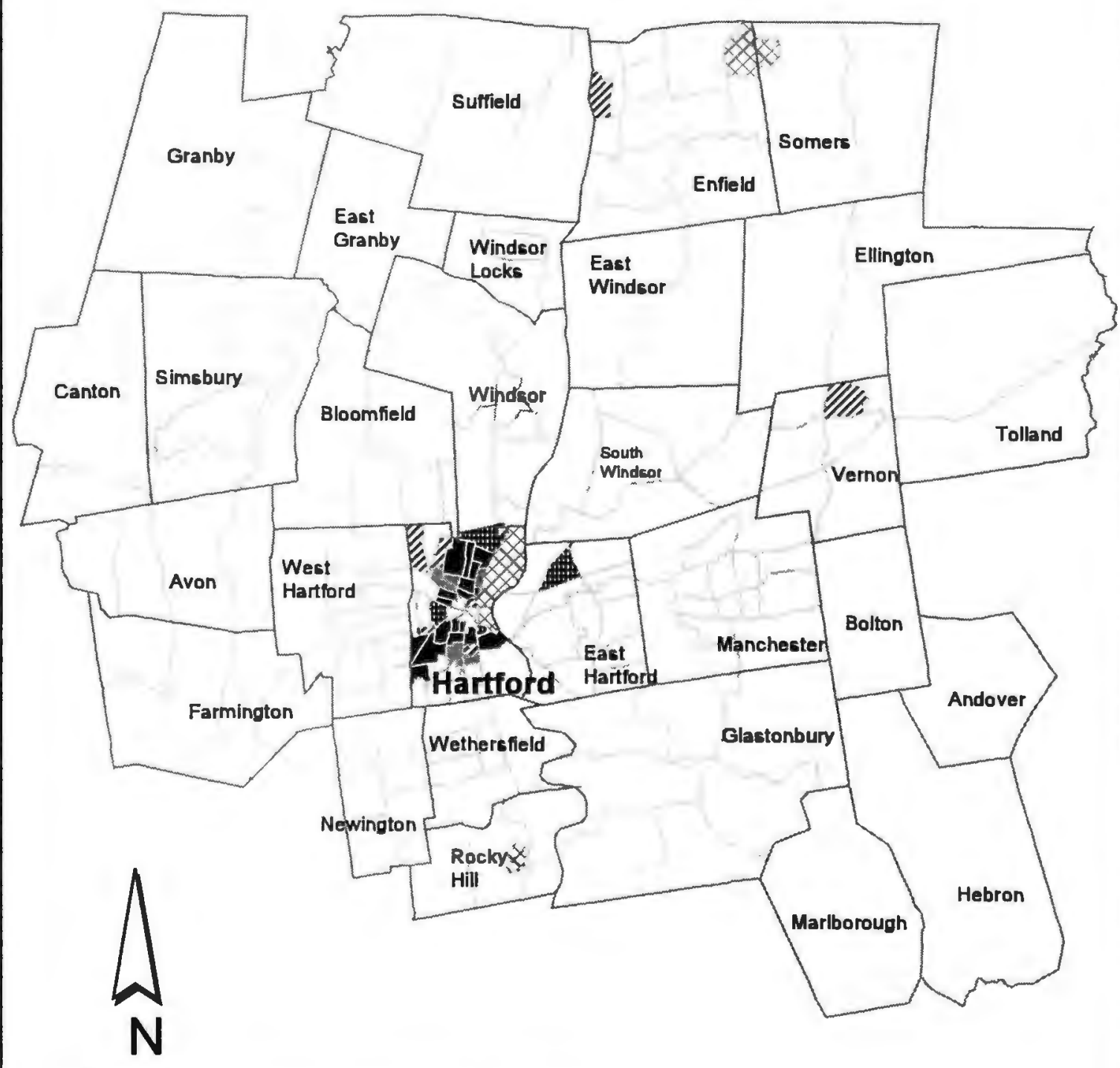

Bottom 20 percent on any three measures ${ }^{* *}$

Bottom 20 percent on three measures plus teenage dropout

Bottom 20 percent on four measures, excluding teenage dropout (Distressed tract)

Bottom 20 percent on four meaures plus teenage dropout (Severely distressed tract)

- Tracts simultaneously rank in the bottom 20 percent of the region for each measure.

- Distresced measures include percentage below poverty, on public ascistance, unemployed, and female head of household.

* Institutional Tracts

Distresced characteristics not applicable

\section{$0 \begin{array}{lllllll}0 & 1 & 3 & 4 & 5 & 6 & \text { Miles }\end{array}$}

Source: 1990 U.S. Census, STF1, Table P16 and STF3, Tables P61, P70, P95, $P 127$, extracted from CD-ROM by author. Boundaries from 1994 U.S. TIGER files. 
There are other tracts that are borderline. These tracts are placed into two classes, modeled after the system used for stormy weather alerts. First comes a "watch" of potential trouble and ratcheted up from there is a "warning" when more critical conditions exist. Tracts that need to be "watched" are those in the bottom twenty percent on any three of the five indicators of a distressed or severely distressed tract (Figure 4). Of these, five are in Hartford. However, two others are in other towns of the region. One is tract 4806 in Enfield and the other is again tract 5302 in Vernon. Four tracts fall into the "warning" class, which means that they were in the bottom 20 percent on teenage dropouts and on three of the other four statistics for distress. Three are in Hartford and one is tract 5103 in East Hartford. This gives East Hartford two potential problem tracts, tract 5106 identified as a mid-poverty tract and tract 5103 as a "warning" tract.

As the next chapter will illustrate, these four suburban tracts $(4806,5302$, $5103,5106)$ are primary sites of tenant-based assisted units. The Enfield tract is that town's primary certificate tract. The East Hartford tracts are part of the concentrated core of tracts but not more so than others in that town. The only data available for Vernon was that from state and mobility programs and therefore townoriginated units could not be mapped. However, the main destination for state and mobility programs is tract 5302 .

Change 1980 to 1990 Rankings

The most significant finding for change in ranking of distressed tracts from 1980 to 1990 is that there is no change. Overall, outside of Hartford, there was 
very little change in the statistics of distress. Of the four suburban tracts noted above, tract 4806 in Enfield was in the watch class then as now, with poor rankings on three of the statistics. The only difference is that while unemployment improved in that tract moving the tract out of the bottom 20 percent in the region for that statistic, teenage dropouts deteriorated, putting the tract in the bottom 20 percent of the region for dropouts. In Vernon, tract 5302 showed improvement, having ranked in the bottom 20 percent in public assistance and unemployment in 1980 and in neither in 1990. In 1980, this tract was the only severely distressed tract in the suburban area; in 1990, while still at risk, it had shown improvement over the decade. Conversely, in East Hartford the rank of 5103 has worsened, with the tract's unemployment record moving it into the bottom of the regional rankings. The only statistic keeping it out of the severely distressed category is its poverty level of 8.2 percent.

Hartford was the site of many problems in 1980 and there has been little overall improvement over the decade. Most of those tracts that were in the bottom in 1980 were still there in 1990.

In tracts in the major certificate-use suburban towns there was some change in the ranking of the individual statistics but none that affected the overall ranking of distress. In East Hartford, two of the primary certificate tracts were ranked in the bottom 20 percent of the region for unemployment in 1990 that were not in 1980. In Manchester, two of the primary tracts were in the bottom ranking for teenage dropout in 1990 that were not in 1980. In addition to the improvements in tract 5302 in Vernon noted above, another tract moved out of the 
bottom 20 percent for employment as well. West Hartford had no change in any of the primary certificate tracts (Appendix 2).

\section{Percentage change}

The rankings show where a tract falls in relation to all 193 tracts in the region. It is therefore possible for a tract to have deteriorated for a particular characteristic yet still not be in the bottom of the rankings because other tracts declined to a greater degree. Or, for the same reason, a tract could have improved in rankings and still have the overall percentage static or decreasing. Therefore, it is necessary to look for any notable changes in the percentage point change for each statistic over the decade. An examination shows very few of the observed rankings changes reflected dramatic drops or increases in percentage point changes. Most of the large changes were in Hartford with many of them indicating a worsening situation. The largest changes in the suburbs occurred in the dropout rate of the age 16 to 19 population, with increases ranging from about 10 to 30 percent more dropouts (eight tracts); however, just about the same number of tracts lowered the dropout rate by similar amounts (seven tracts). Six of the eight worsening tracts have higher numbers of certificates but four of the seven improving tracts do as well.

Other than these changes in teenage dropouts, the suburbs have only a couple other changes. Of note, however, are six tracts which are not in the bottom ranks but do show some of the larger suburban changes. The first tract is tract 4738 in Windsor, a tract that borders Hartford and is the primary destination for portable moves in that town. In this tract, unemployment is greater by 8.7 
percentage points, public assistance by 6.3 , and female head of household by 9.7 . All of these indicate movement in a negative direction; still, teenage dropouts for this tract improved from 1980 by 8.6 percentage points (Appendix 3 ).

Two other suburban tracts where percentage change is notable are in West Hartford. Tract 4971 is one of the central core of certificate destination tracts and also borders Hartford. In this tract, unemployment is worse by 5.9 points and teenage dropouts by 8.0 . Yet, West Hartford's tract 4973 has no rental certificate units, also borders Hartford, and has experienced a similar unemployment increase of 6.6 points. In Bloomfield's tract 4712 public assistance has increased by 5.0 percentage points. In East Hartford's tract 5113 unemployment is up 5.8 points and in Manchester's 5142 female-headed households up 5.0 points. All three tracts are part of each respective town's core of certificate tracts. Of course all of these suburban changes, including the teen dropouts, reflect the 1989 situation. The current generation of certificate-tenants cannot account for those changes; what can be noted is that some of the tracts which are now high certificate tracts were in flux in the 1980 s before the program began.

Still, for those movers who left Hartford for other towns in the region, the move most likely put them in a better place. The legislative changes that invented portability certainly allowed participants to consider areas with many fewer distressed characteristics than the tracts of Hartford. A handful of suburban tracts experienced some decline, but a few others also improved. None is in the same category of distress as the tracts of Hartford. 


\section{Rental desirability indicators}

In this section, the region is divided into three classes which corresponds to the level of certificate use in the suburban towns. In each class, the focus is on the certificate destination tracts but also noted is where opportunity may exist to disperse the concentration of certificates. Finally, the study examines whether any patterns and change occurred from 1980 to 1990 . The statistics that comprise the rental desirability index are the amount of rental property, the amount of vacant rental property, rental affordability to those at 50 percent of the region's median income, and presence of school age children. A highly desirable rental tract ranks above the regional mean on three of the four statistics. Since the characteristics of the distressed index often correspond to areas with rental property, any tract that was identified as distressed was ineligible for the rental indicator. A warning or watch tract is still available for consideration, but with obvious caution.

\section{Desirable Rental Tract} Above the regional mean on 3 of 4 rental characteristics.

Amount of rental property Amount of vacant rental Affordable to renters at $50 \%$ of regional median income Presence of school age children

\section{Primary towns}

The towns in this class are those that have the largest numbers of certificates in use (Table 7). It includes East Hartford, Enfield, Manchester, Vernon, West Hartford, and Windsor. With the exception of one tract in a rural 
town, all highly desirable suburban rental tracts were in these six towns (Figure 5). ${ }^{14}$

\section{Enfield}

Of these towns, Enfield is the most distant from Hartford; it is more likely affected by the city of Springfield, Massachusetts than by Hartford (Kowalewski 1996) (Figure 6). Still, it does receive some Hartford Special Mobility Program moves as well as from other regional towns and state agencies. It is also the location of one of the nine suburban tracts indicated as desirable to a renter, tract 4806. This tract is one of the watch tracts, so its designation as a desirable tract is somewhat qualified.

Two other tracts in Enfield are above the regional mean for affordability $(4805,4807)$ and one of these for amount of rental property as well $(4807)$. As far as change from 1980 , tract 4805 moved into the affordability rankings with a percentage point increase of 14.1 of affordable rental property. Other changes included an increase in rental property of 10.6 percent in tract 4806 , an increase in affordability in tracts 4807 (18.1 percent), 4809 (13.8 percent), and 4810 (18.2 percent). Three tracts had strong decreases in affordability: 4802 (21.0), 4803 (31.7), and 4811 (51.1). With the exception of tract 4806, all Enfield tracts have fewer than 14 certificates, with most in the zero to five range.

\footnotetext{
${ }^{14}$ Hartford does have some tracts that are not distressed and are counted as desirable using this criteria. However, this study focuses on the other towns of the region.
} 


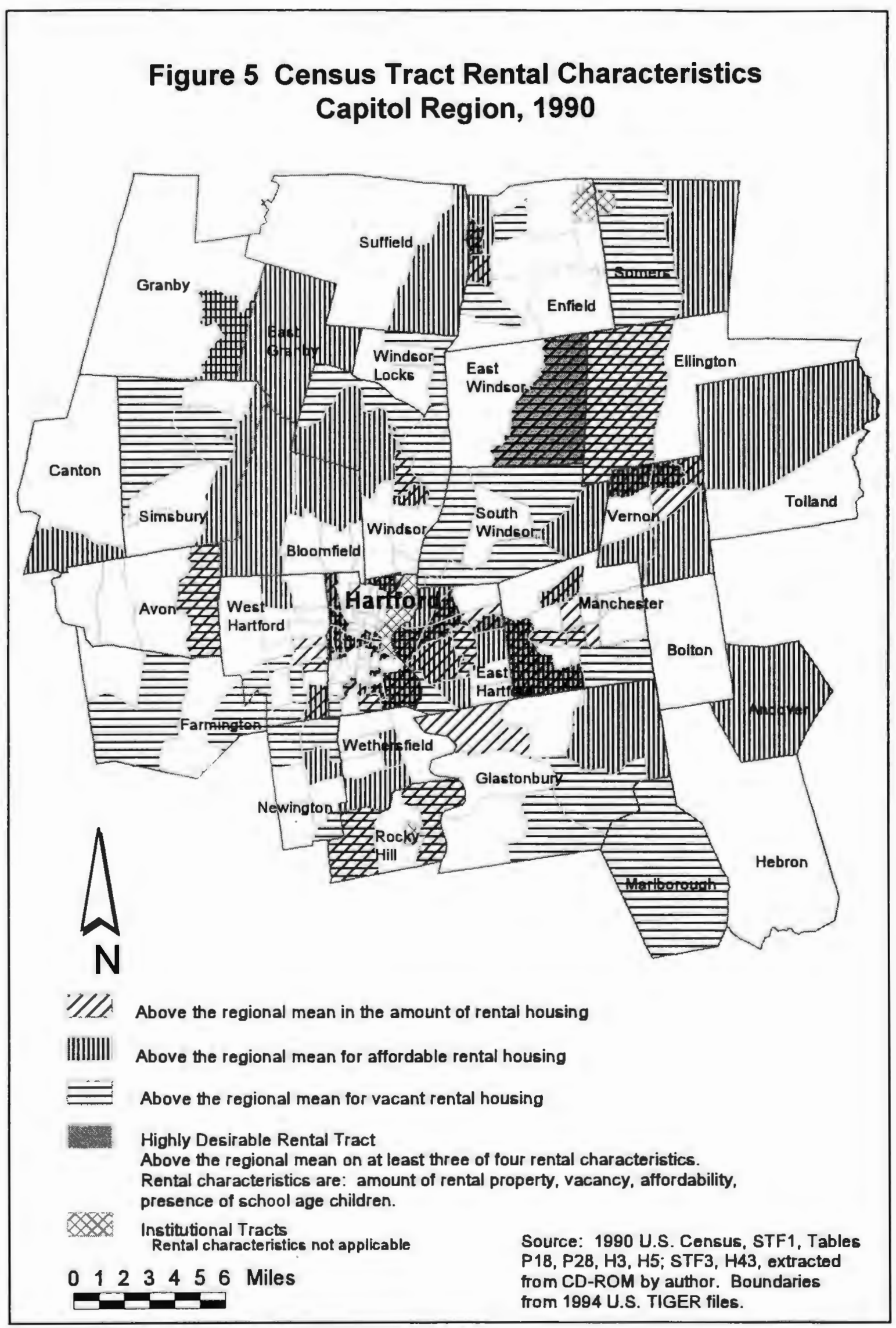




\section{Figure 6 Enfield Rental Characteristics}

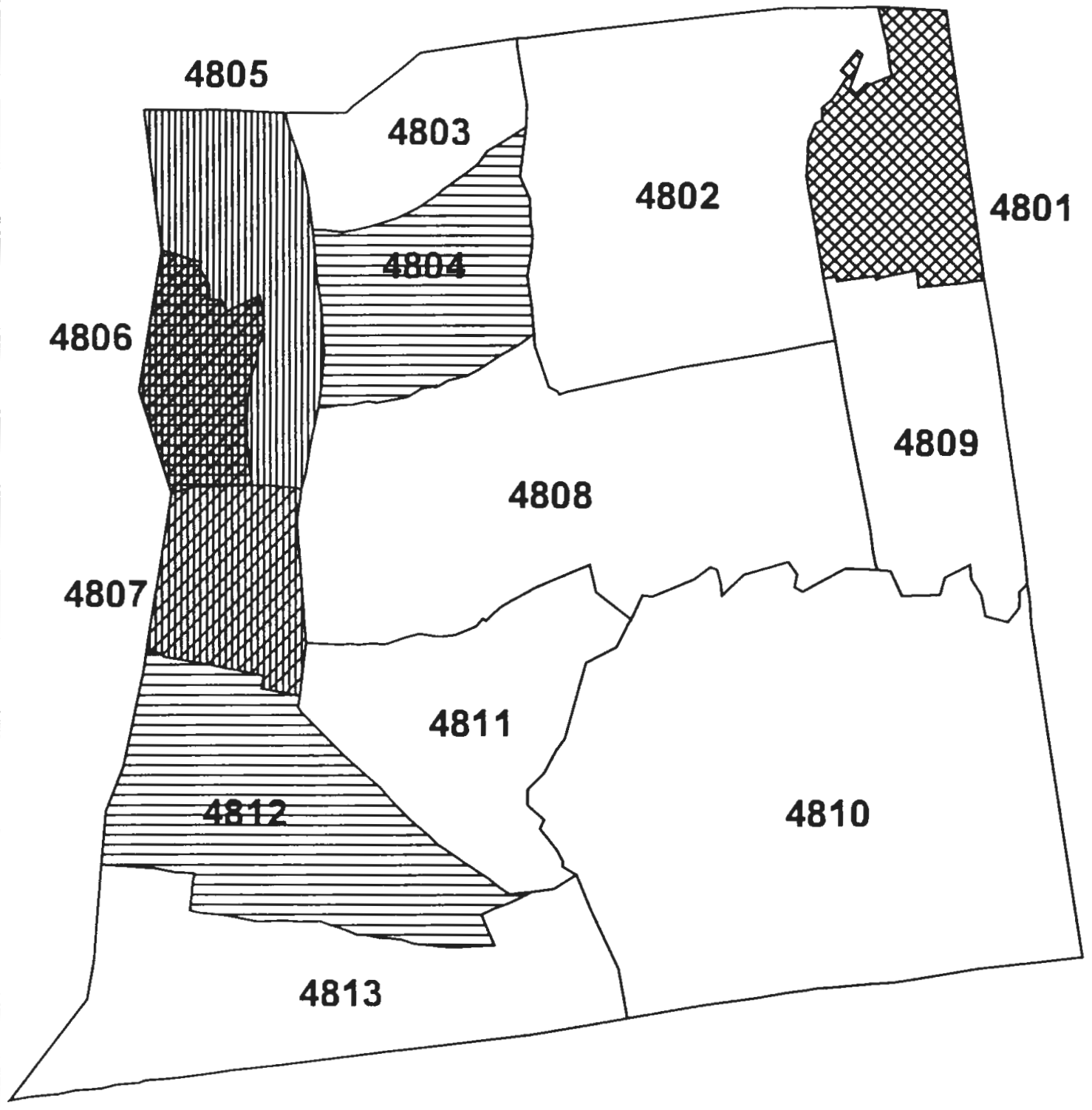

27 Above the regional mean in the amount of rental housing III. III Above the regional mean for affordable rental housing Above the regional mean for vacant rental housing Desirable rental tract Institutional tract Tract boundaries

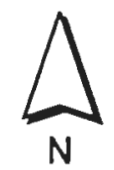

Source: 1990 U.S. Census, STF1, Tables P18, P28, H3, H5; STF3, Table H43. Boundaries from 1994 U.S. TIGER files. 


\section{Windsor}

Windsor is an intermediate town that is the smallest in this primary town group for number of certificates but considerably larger than any of the secondary towns. It does not have any tracts labeled as highly desirable but it does have tracts with some desirable components (Figure 7). Paradoxically, the tract with the most portable certificates, tract 4738 , has none of the characteristics although in 1980 it was regionally ranked for affordability. This tract has also experienced a 9 point decrease in amount of rental property and a 16 point fall in rental vacancies. Tracts 4734 and 4736.02 are both currently ranked above the regional mean for the amount of rental property with the first also ranked in affordability and the latter in vacancy as well. Both also have some certificate units. Tract 4735.01 is ranked as an affordable tract but it has experienced a decrease in the amount of affordable rental units by 30.3 points, suggesting it is becoming less affordable. $\underline{\text { Vernon }}$

Vernon has two tracts that are designated high rental tracts, 5302 and 5303.01 (Figure 8). Tract 5302 is marked such with caution because of its previous designation as a watch tract. In this town, four tracts are ranked above mean for amount of rental property and all but two for affordability. During the 1980s, three tracts increased in affordable units, most notably tract 5306 by 38.6 percent moving it into the rankings of regional affordable tracts. Tract 5302 did not change over the decade. 


\section{Figure 7 Windsor Rental Characteristics}

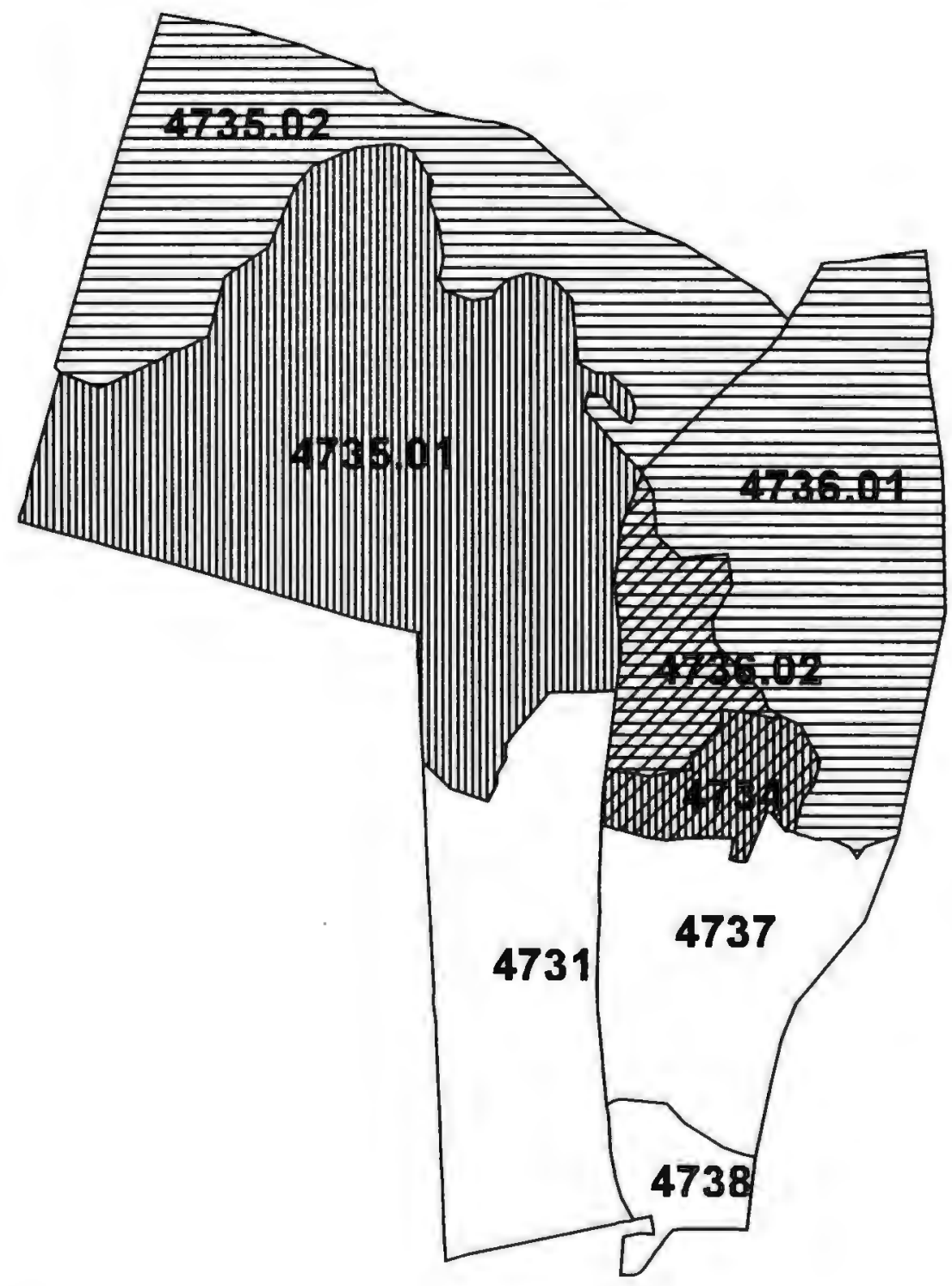

VIn

Above the mean in the amount of rental housing

Above the regional mean for affordable rental housing

Above the regional mean for vacant rental housing

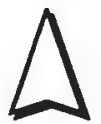

N

Tract boundaries

D

$$
1
$$

2 Miles

Source: 1990 U.S. Census, STF1, Tables P18, H3, H5; STF3, Table H43.

Boundaries from 1894 U.S. TIGER files. 


\section{Figure 8 Vernon Rental Characteristics}

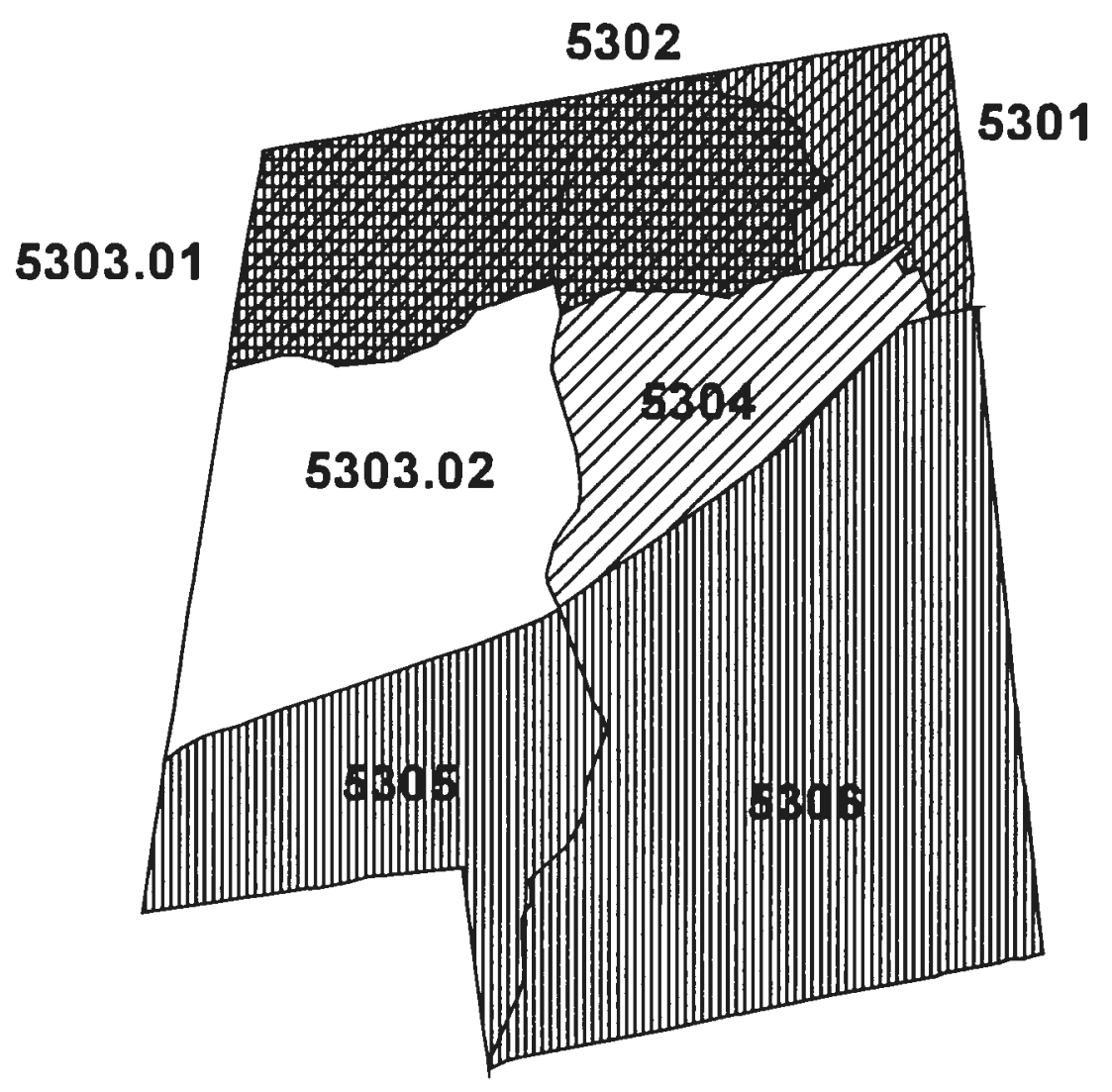

Q7] Above the regional mean in the amount of rental housing

[IIU] Above the regional mean for affordable rental housing

Above the regional mean for vacant rental housing

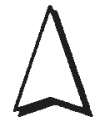

N

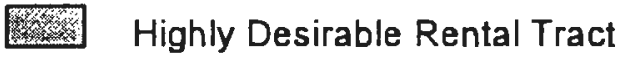

Tract boundaries

0

1

2 Miles

Source: 1990 U.S. Census, STF1, Tables

P18, H3, H5; STF3, Table H43.

Boundaries from 1994 U.S. TIGER files. 


\section{East Hartford}

East Hartford, the town with the most tenant-based units, has four high rental-desirability tracts: tracts $5102,5103,5104$, and 5112 (Figure 9). Of these, tract 5103 is a "warning" tract. Almost all of the current certificate destination tracts in East Hartford were ranked above the regional mean in amount of rental property in 1990. Ten tracts are either ranked in affordable or vacant or both. The three tracts with fewer than five certificate units have none of the rental characteristics. As far as change goes, there was very little change in rankings although five tracts saw 13 percent and greater increases in their percentage of rental units that were affordable. Historically and currently, East Hartford possesses the qualities upon which a market-based, tenant assistance program relies.

\section{Manchester}

Manchester has one tract, 5151.02 , that is classified has a highly desirable rental tract and that tract is not one of the top certificate-unit tracts. Most of the primary certificate tracts are ranked above mean in amount of rental property, only two for vacancy and one for affordability. There were nine tracts, however, whose rentals became more affordable over the $1980 \mathrm{~s}^{15}$ Still, regional rankings were relatively unaffected. Affordability within the town increased but relative to the region, it did not move into the above mean rankings.

\footnotetext{
${ }^{15}$ Those tracts, with increases ranging from 8.4 to 34.0 percent but most in the low teens, are: $5141,5142,5143,5144,5145,5148,5149,5150,5151$.
} 


\section{Figure 9 East Hartford Rental Characteristics}

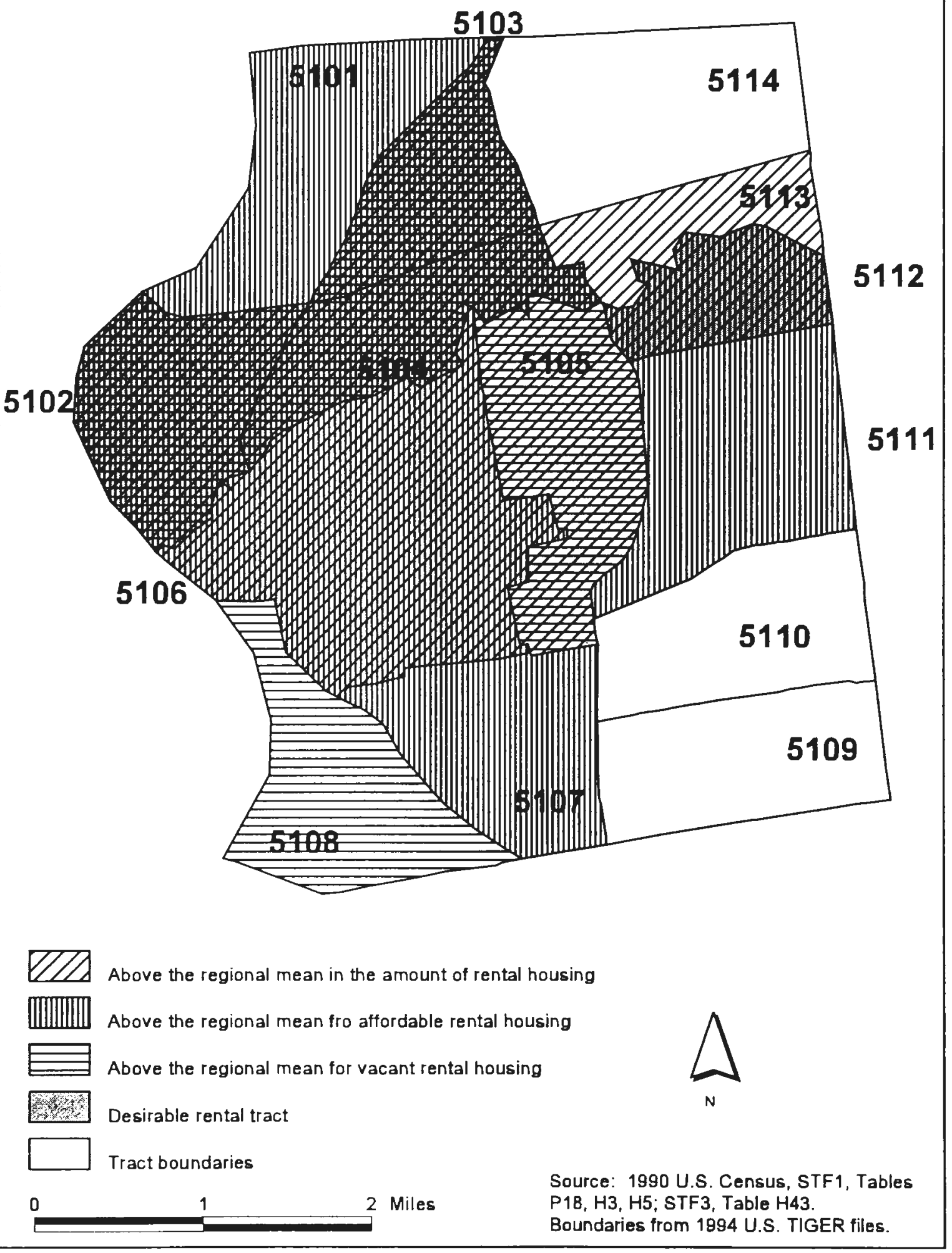




\section{Figure 10 Manchester Rental Characteristics}

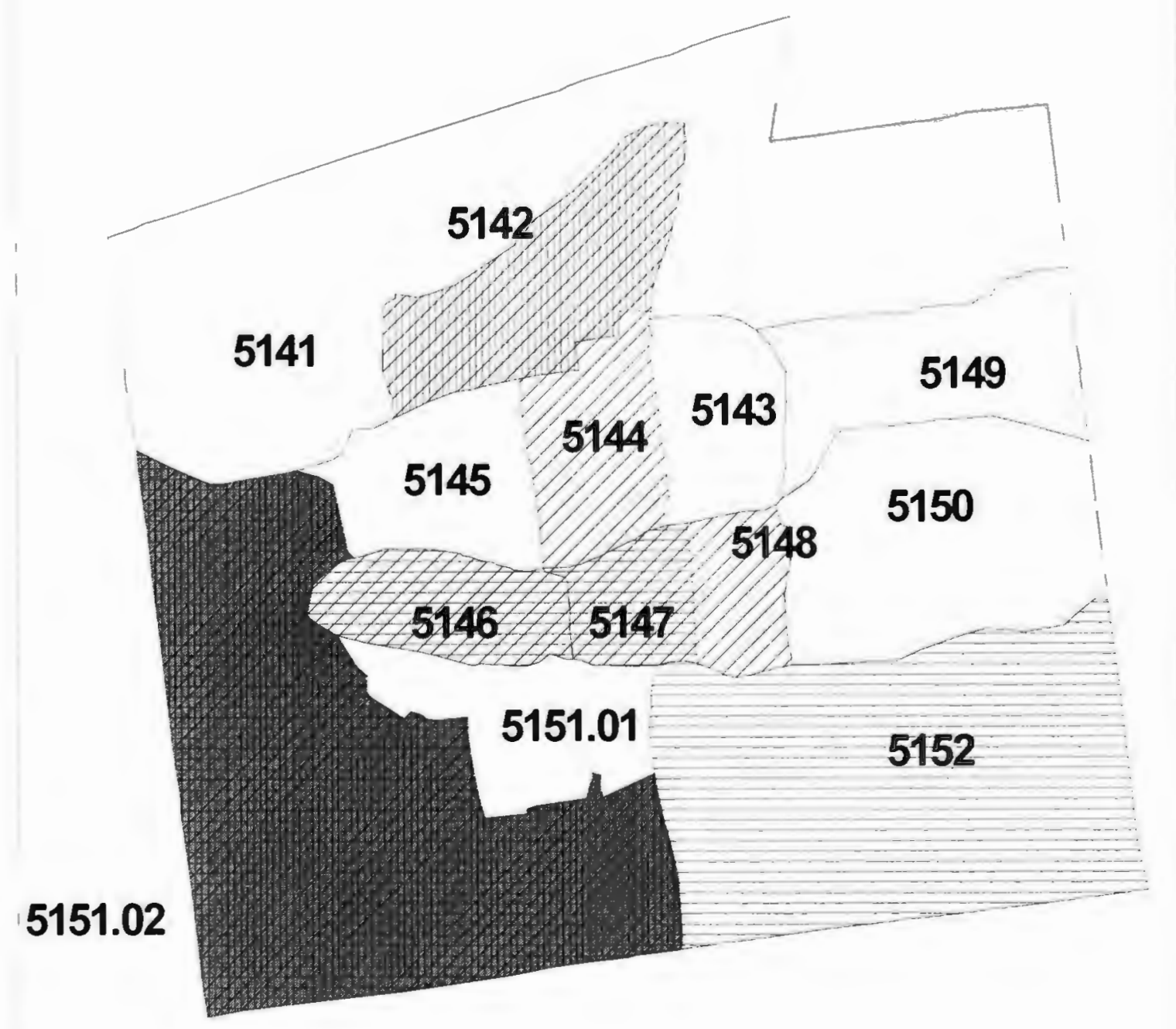

D2. Above the regional mean in the amount of rental housing

Above the regional mean for affordable rental housing
Above the regional mean for vacant rental housing
Desirable rental tract

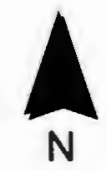

Tract boundaries

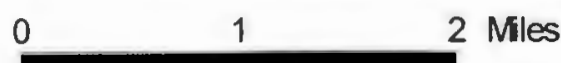

Source: 1990 U.S. Census, STF1, Tables P18, H3, H5; STT3, Table H43. Boundaries from 1994 U.S. TIGER files. 


\section{Figure 11 West Hartford Rental Characteristics}

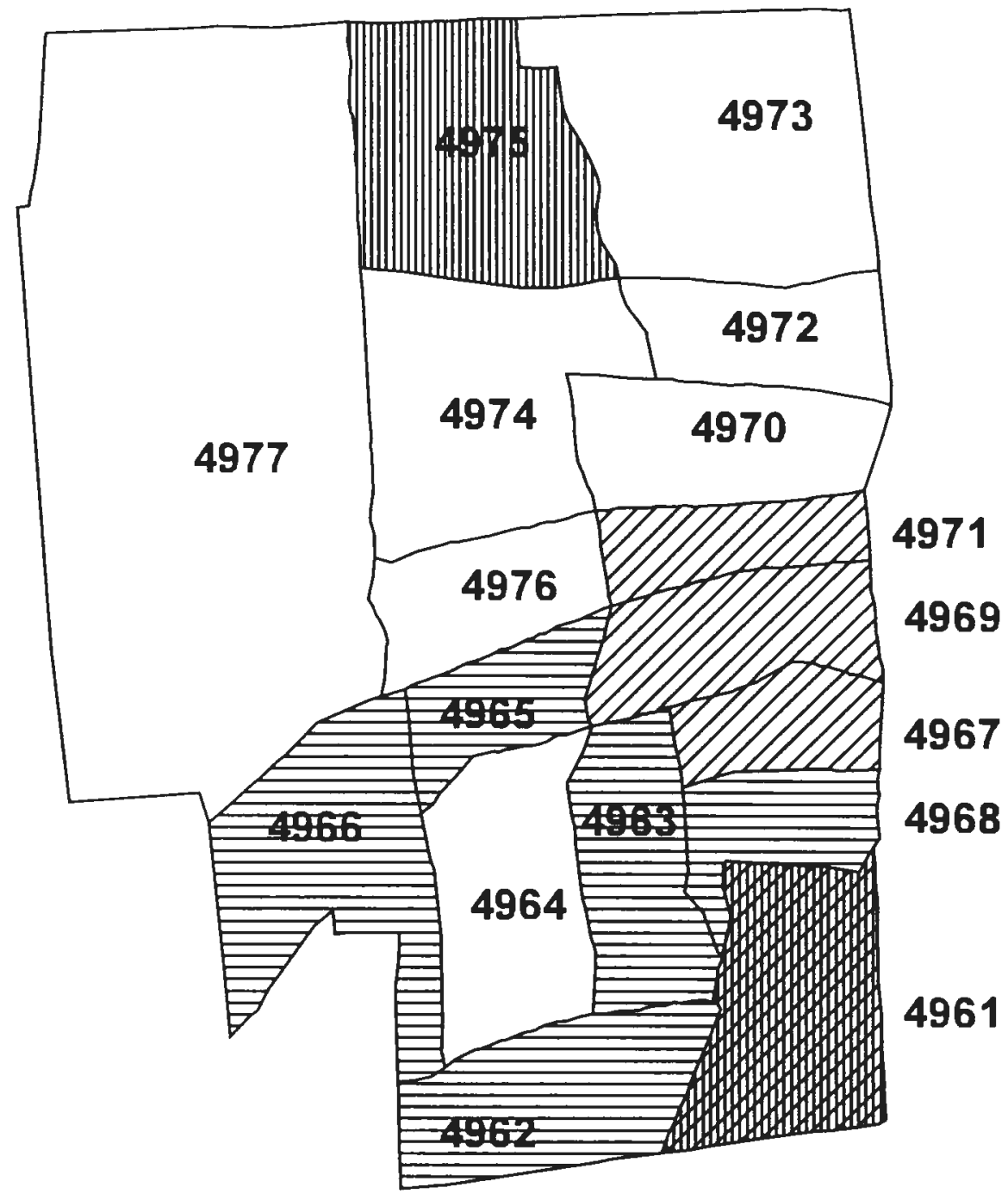

Above the regional mean in the amount of rental housing

Above the regional mean for affordable rental housing

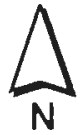

Above the regional mean for vacant rental housing

Source: 1980 U.S. Census, SFT1, Tables

Tract boundaries

0

2 Miles

P18, H3, H5; STF3, Table H43. Boundaries from 1994 U.S. TIGER files. 


\section{West Hartford}

The final primary town is West Hartford. This town has no tracts that possess a minimum of three of the rental statistics and is the lowest of the primary towns for percentage portable certificates to total certificates. However, most of the primary certificate tracts are ranked above the regional mean for amount of rental property, and of these, five are above mean for vacancy as well. None of these same five was ranked for vacancy in 1980 indicating some changes in these neighborhoods.

\section{Primary town summary}

Overall, for these primary certificate towns, the amount of rental property rather than affordability appears to be a common denominator. More of the destination tracts are ranked above the regional mean for amount of rental property than other characteristics. Still, intra-town affordability appears to have some effect, particularly in Manchester. Finally, there appears to be some opportunities, at least based on rental characteristics, within these towns to disperse some of the intra-town concentration. Tract 5151.02 in Manchester, tracts $4975,4962,4965$, and 4966 in West Hartford, tracts 4805 and 4807 in Enfield, and tracts 5107 and 5111 in East Hartford all offer characteristics on which a rental assistance program can capitalize and they are not primary certificate tracts. 
Secondary towns

The towns in this category show much less consistency from town to town in location of primary certificate tracts relative to the rental indicators. Notably, several of the towns have very few portable units (Table 7). Much of the story in this set of towns is of opportunity. There are tracts that ranked as affordable but are not the location of tenant-assisted units (Figure 5). This seems to be consistent with the observation in the primary towns that the amount of rental property was more of a location factor than affordability. Still, it may be possible to utilize these affordable tracts to a limited degree if their presence is more widely known and if other barriers, such as transportation, are overcome.

Bloomfield has two tracts ranked as affordable, yet neither one is a certificate-unit tract. And throughout the town, change was minimal from 1980 to 1990. Farmington has one primary tract where certificate-holders locate and it is ranked above mean solely for school age children. Other than that, there was nothing of note and no change over the 1980 s.

The situation is much the same for the other towns in this class. Newington has one tract, 4944, ranked as affordable, a change from 1980 when it was not. South Windsor's tract 4872 is ranked as affordable and three others in this town as vacant one of which, 4875 , is the town's primary certificate tract. Wethersfield has three affordable ranked tracts of which two are town primary certificate tracts $(4922,4926)$. Windsor Locks' certificate target tract, 4761 , was ranked above the regional mean on vacant rental units, a change from 1980 when it was not. And 
finally, Glastonbury's only affordable-ranked tract has no certificates although the primary certificate tract is ranked for rental units.

\section{Tertiary towns}

In the final class of towns is the last tract classified as a high rental desirable tract (Figure 5). That tract is 4842 in East Windsor; however, it is not ranked for affordability. Others of these relatively more rural towns do have affordable tracts including Suffield, Somers, Canton, Simsbury, East Granby, Tolland, and Andover. Tracts that are ranked for amount of rental units are Somers, Ellington, Rocky Hill, Marlborough and Simsbury. Of course, most of these towns only have one or two tracts, which makes it difficult to assess the area accurately. Changes from 1980 were limited to a few vacancy ranking changes and one tract moving into the affordable ranks while another moved out.

The usefulness of this analysis is the recognition that these rural areas do offer some potential for a program which relies on the market for rental units. There are pockets of affordability and rental properties. Knowledge of this information can assist decision-makers in opening up more options for certificate households. Again the most evident barriers are transportation and potential isolation from one's support network.

\section{Indicator summary}

Overall, the analysis of distress and desirability indicators has proved fruitful. By pinpointing distressed tracts, it is clear that Hartford movers benefit 
from the portability program. Moves out of Hartford mean moves away from distress. There are a few suburban warning tracts but these are no more the destination than other desirable tracts and these warning tracts are not as distressed as any Hartford tract.

Another observation is that the Hartford Special Mobility program is functioning to open up opportunities to Hartford residents. It is growing in size although its distribution is unevenly dispersed. The additional certificates in some of the more rural towns in 1996 show steps, albeit small ones, towards better regional dispersion. Some precautions may need to be taken to assure that East Hartford doesn't continue to dominate the program. And if the experience with West Hartford is indicative, the ability to work directly with landowners in other towns is key to successful growth.

Certainly it is no surprise that the inner ring towns of the region receive most of the moves. Still, opportunities exist in the more rural areas. Concentration, whether in towns with many or few certificates, tends towards tracts with greater amounts of rental property; affordability is less important. The next chapter will delineate concentration factors in greater detail. 


\section{CHAPTER FIVE: LOCATION ANALYSIS}

This chapter addresses the two remaining research questions: 1) Is the outcome of one type of assistance different from another? And 2) Does tenantbased rental assistance concentration exist? If so, how is it defined and where is it located? The first section addresses question one by comparing maps of each aspect of the certificate programs. Second, the mapped results are used to identify areas of concentration. The methodology used in the development of a definition for concentration precedes the presentation of results.

\section{Program comparison}

The first program feature of note is that, as is common in a metropolitan area, the inner ring of towns surrounding the main city are the site of and destination for most of the portable certificates, both from Hartford and other towns (Figure 12). Proximity to Hartford, accessible public transportation, affordable units, job and educational opportunities, personal and professional support networks, and relatively greater degrees of race and economic diversity all play a role in this location selection outcome.

Another regional theme can be observed in the map of town-based units (Figure 13). In most towns with tenant-assisted units, one can observe a concentrated core of units. Even in the secondary towns with few certificate units such as Newington and Wethersfield, the initial look of more dispersed units 
Figure 12 Portable Programs

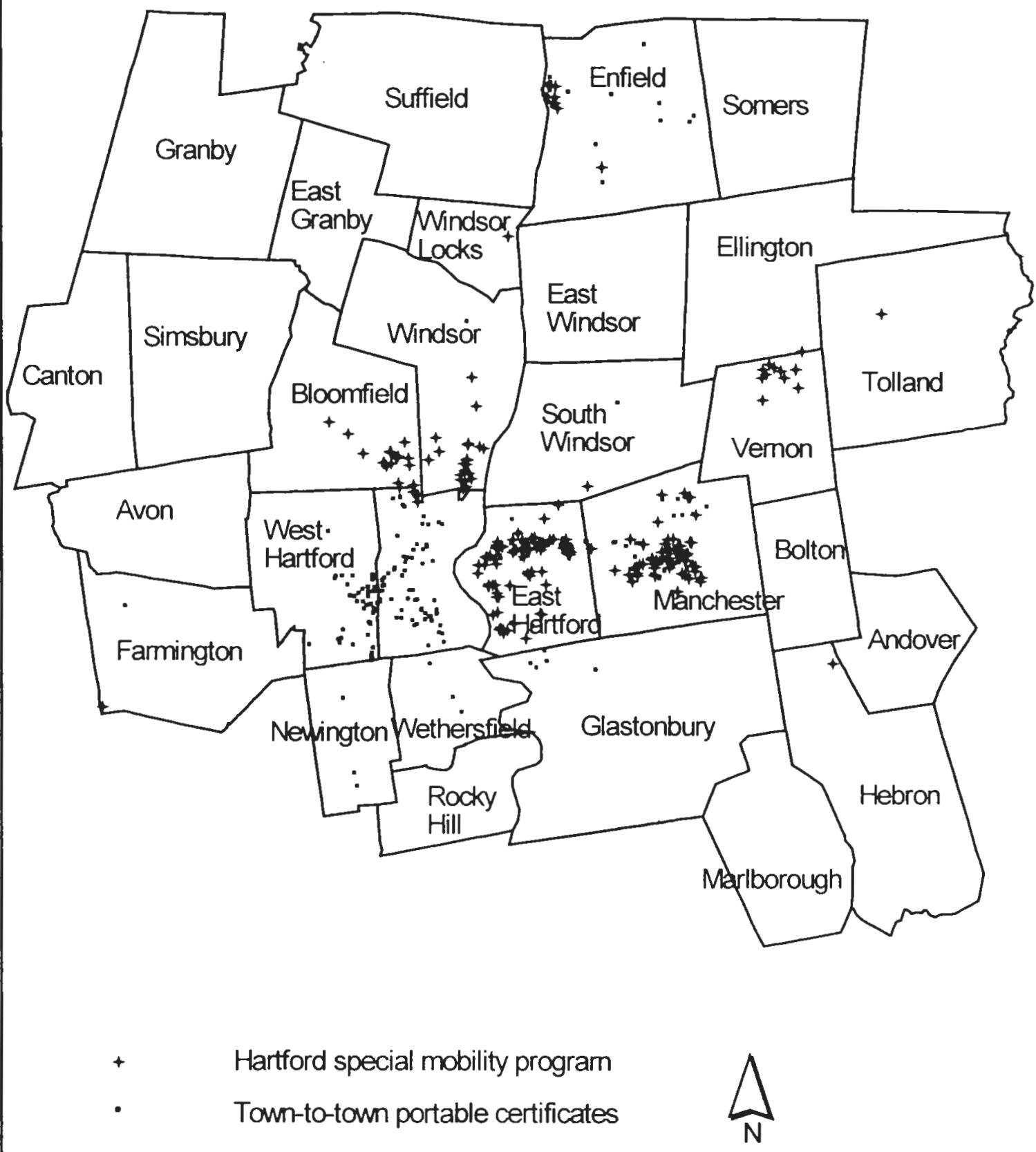

$\begin{array}{lllllll}0 & 1 & 2 & 3 & 4 & 5 & 6\end{array}$ Miles

Source: Mobility program from Imagineers, portable certificates from housing authorities in respective towns, Spring, 1996 Boundaries from 1994 U.S. TIGER files. 
Figure 13 Town Programs

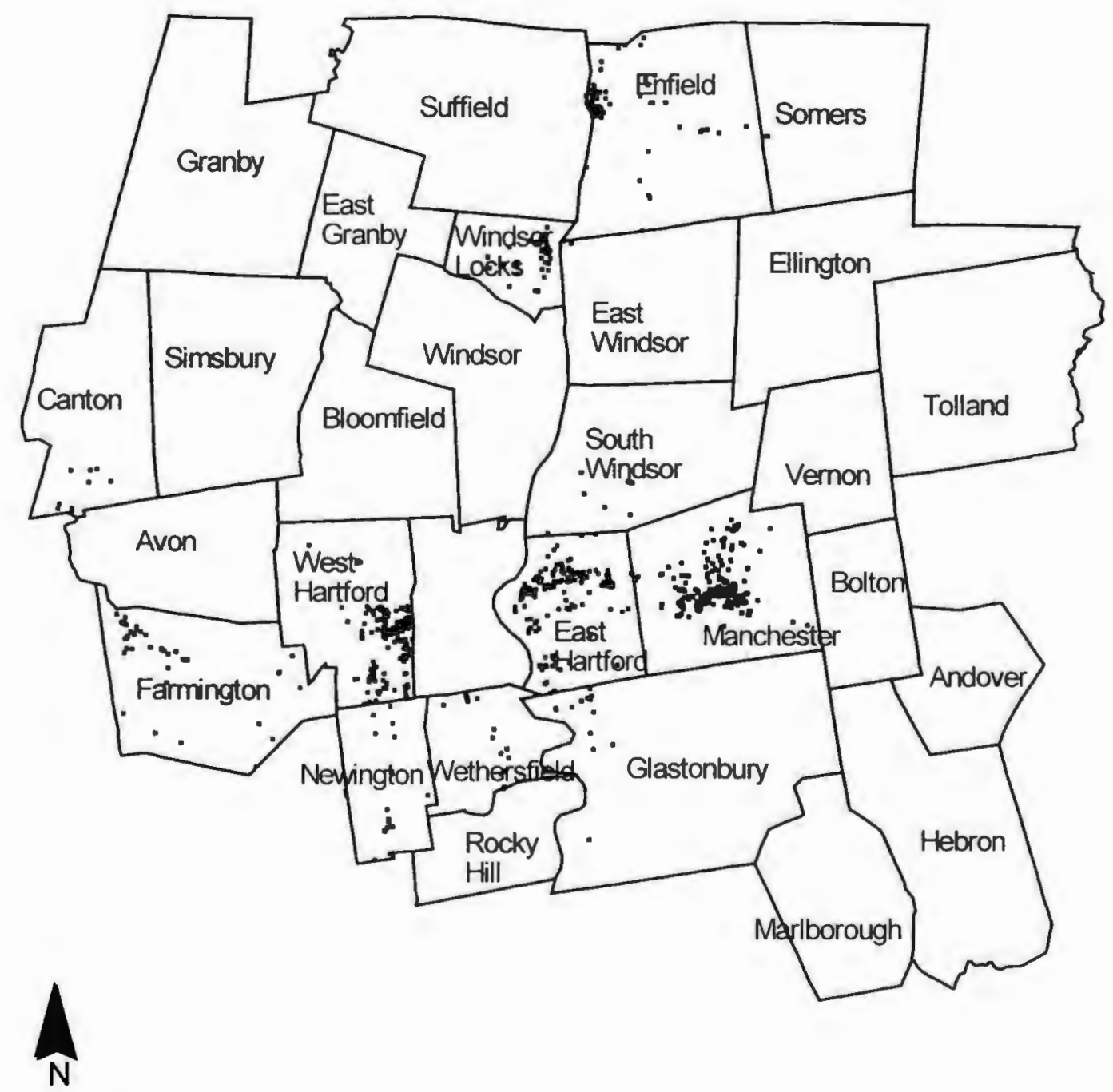

- Town-orignated, town-based certificates*

"The towns of Hartford, Vernon, and Windsor did not provide town certificates data in a form suitable for mapping.

Source: Certificate data from the Housing Authorities in the towns of: Canton, East Hartford, Enfield, Farmington, Glastonbury, Manchester, West Hartford, Windsor Locks.

\section{Miles} Imagineers provided data for. Newington, South Windsor, Wethersfield. Spring 1996. Boundaries from 1994 U.S. TIGER files. 
disappears on closer inspection. Without intervention, development typically does not result in affordable housing available throughout communities. Instead this housing type is generally clustered in certain parts of town. Hence the accumulation of government-assisted housing units in programs dependent on the market to provide affordable housing.

Despite this intra-town clustering, regional certificate density strongly echoes regional population density. A comparison of the density of population throughout the Capitol Region with the density of all certificate units shows very similar location patterns (Figures 14, 15). As later results reveal, there are tracts that meet various concentration definitions. However, overall settling reflects the same patterns as the general population.

The final regional observation compares all three program maps, townbased, portable units, and state programs (Figures 12, 13, and 16). If one looks at the towns with the greatest amount of intra-town concentration, Manchester, East Hartford, Enfield, and West Hartford, regardless of the program, the units are located basically in the same core tracts. It is not the case that those tenants using portable certificates are more likely than those using state- or townoriginated certificates to locate in particular tracts. High numbers of portability units go hand-in-hand with high numbers of town-based units. The tracts with larger amounts of certificates offer the combination of qualities needed by lowincome renters. And, as noted above, certificate density equates to population density. Restrictions to portability programs will do nothing to reduce intra-town concentration; the selection of tracts seems to be limited, regardless which avenue 
to assistance a tenant uses. Chapter Four on census data does identify some potentially under-utilized tracts and some common traits in the tracts that are heavily selected. Town officials who are more familiar with their own town's particularities might find it useful to apply this information in combination with local knowledge to expand town opportunities and reduce intra-town concentration. 
Figure 14 Certificate Density

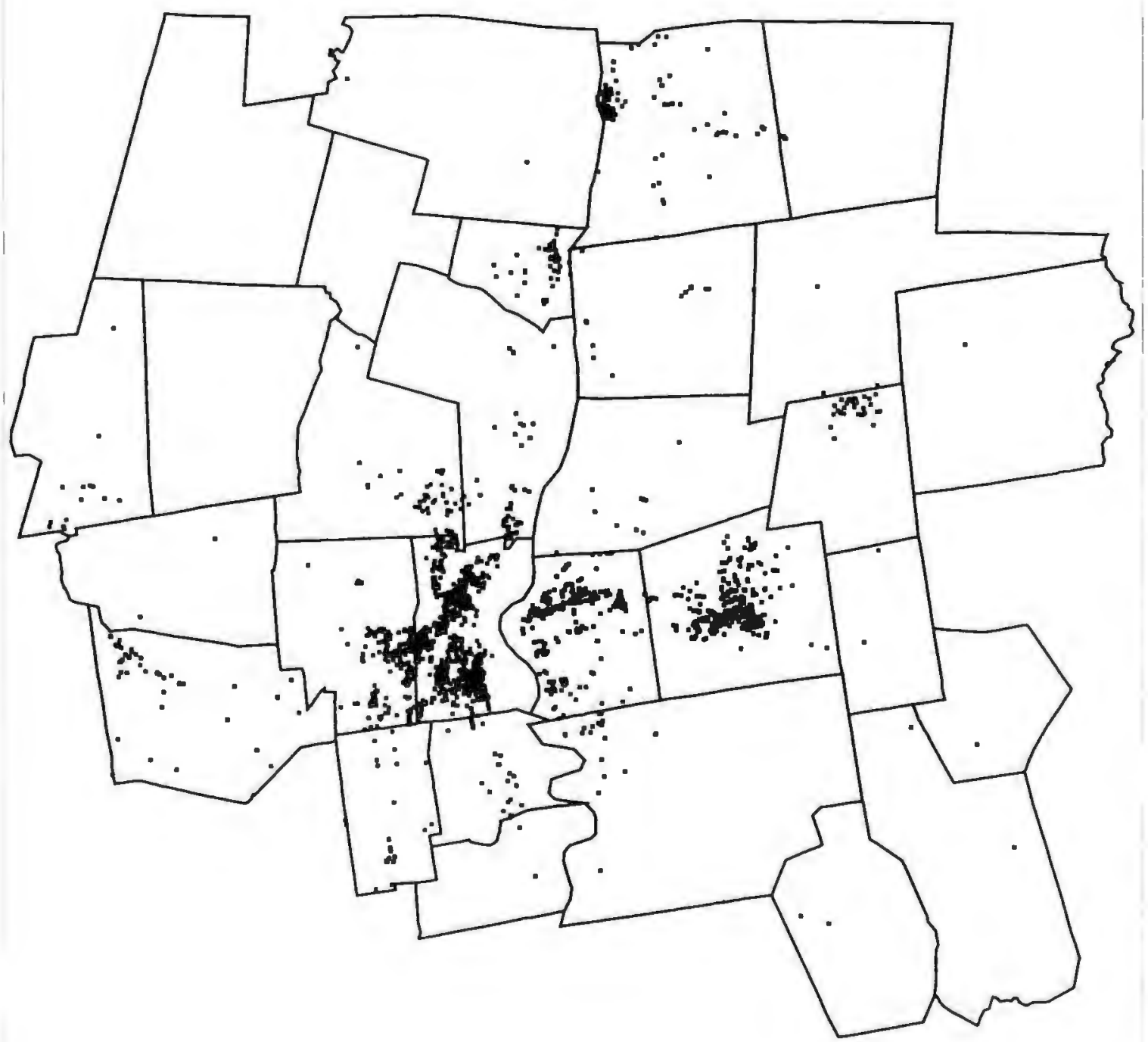

Certificate units
One dot equals one household unit

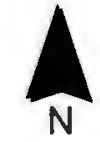

Source: Certificate data from the Housing 
Figure 15 Household Density

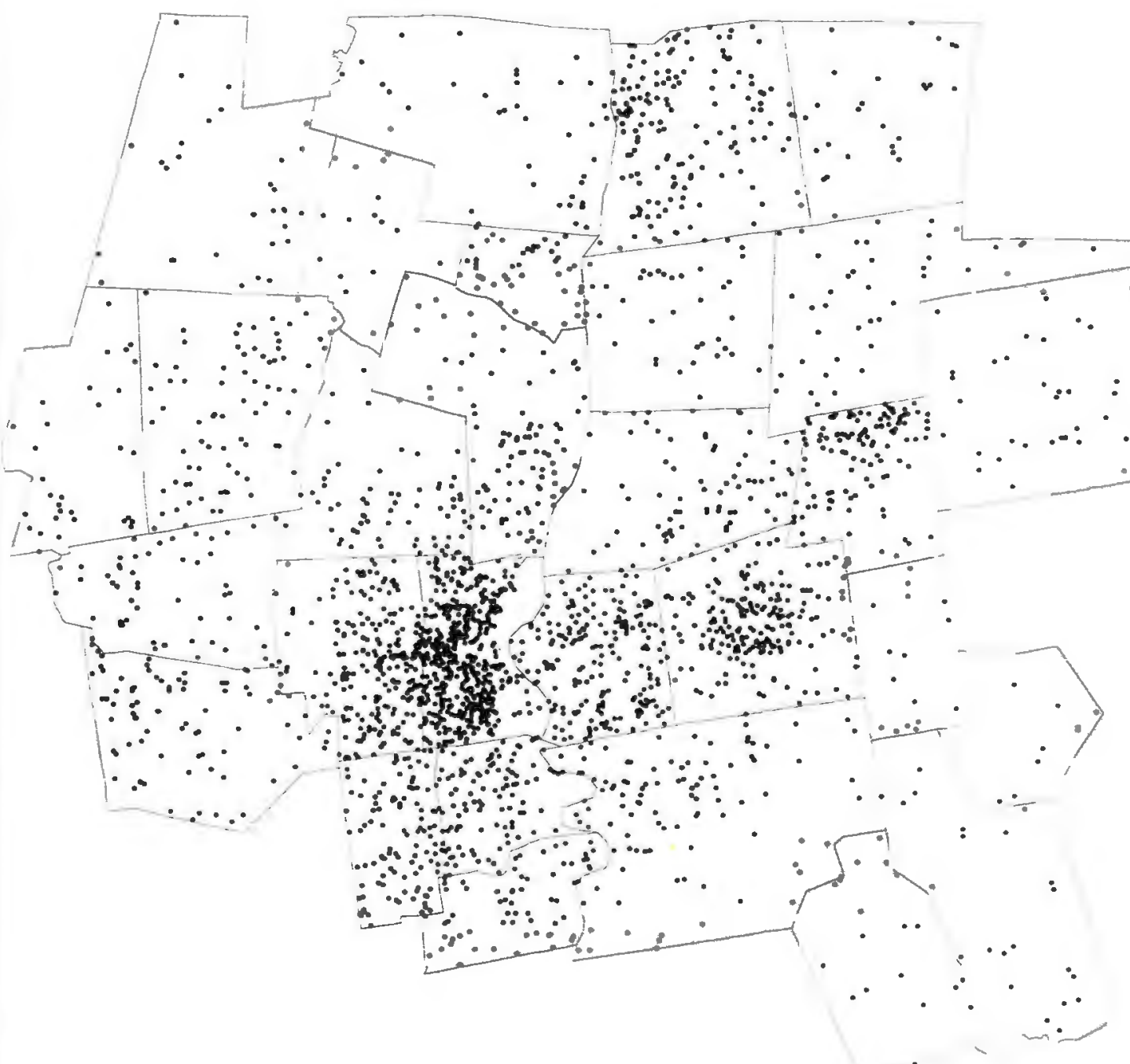

Household ynits

One dot equals 100 households

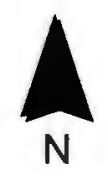

0123456 Miles

Source: 1990 U.S. Census, STF1, Table P3, extracted from CD-ROM by author. Boundaries from 1994 U.S. TIGER files 
Figure 16 State Programs

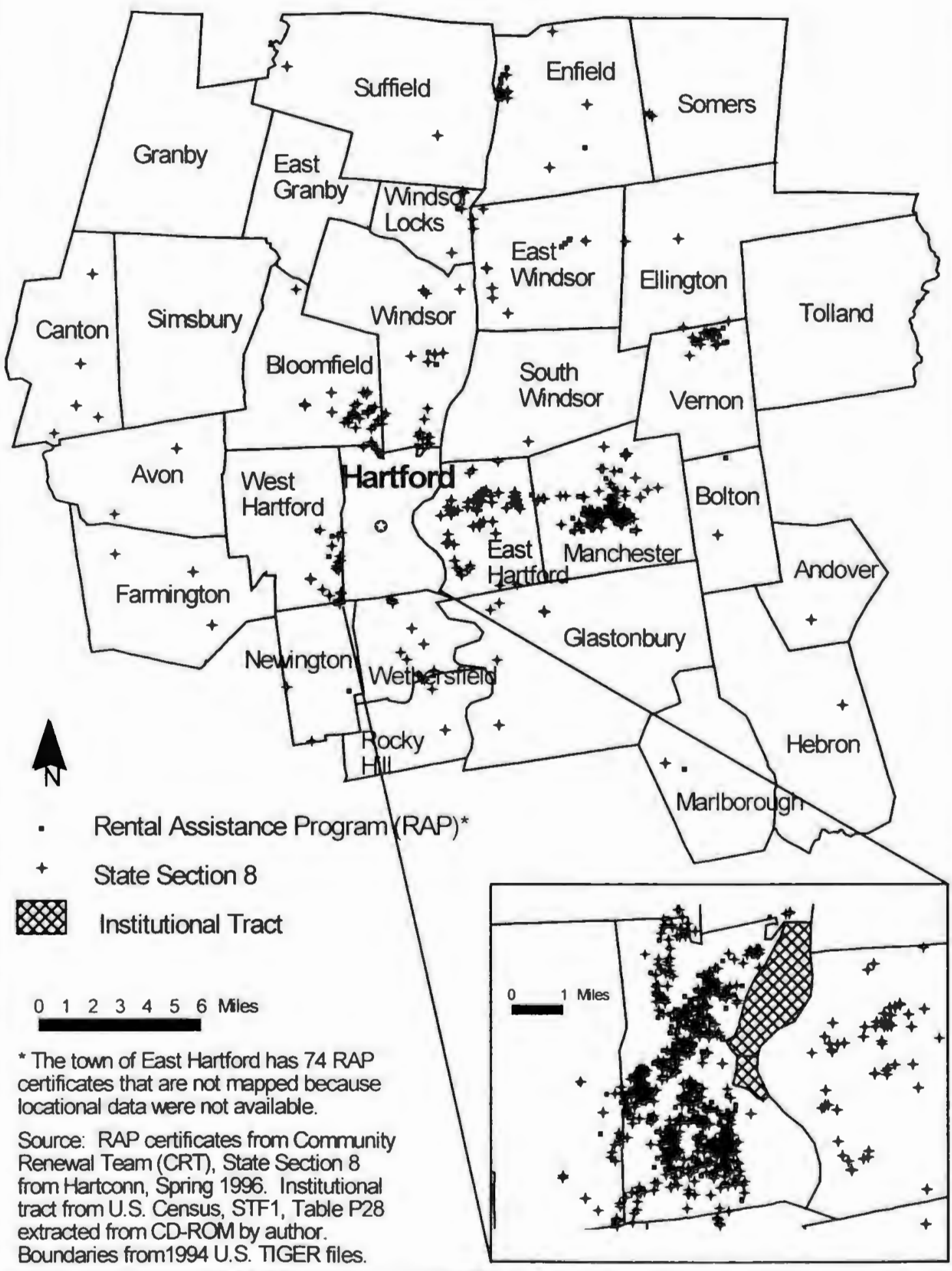




\section{The concentration methodology}

The author conducted an analysis of certificate concentration that combined the number of certificates in a tract with race and income data. In addition, because various entities differ on concentration definitions and needs, this study implements two versions each of race and income standards.

The first measurement tool uses current HUD standards. HUD looks at both race and income percentages without regard for the number of certificates in an area. The HUD definition of a concentrated tract is important to establish because it is one of the conditions that must be met before HUD will intervene in the housing affairs of a community or program. According to Carl Harris, the Equal Opportunity Specialist in the Connecticut State Office of HUD, a concentrated tract

\section{HUD Concentration Definition:}

Any tract that significantly exceeds the total community percentage of minority or low-income population. is any tract that significantly

exceeds the total community

percentage of minorities

and/or low income levels

(Harris 1996). The minority measurement sums together Black, Hispanic,

Asian/Pacific Islander, and Native American populations. The income

measurement is set at two levels: very low, or 50 percent of each town's median income, and low, or 80 percent of town median income. Even though a particular tract may meet the HUD definition of concentration, it does not necessarily follow that HUD intervention is automatic. Exceptions may include areas undergoing community revitalization, engaged in a housing rehabilitation project, or when town 
planning and development departments follow other definitions of concentration (Harris 1996).

The HUD definition is limited, primarily because it relies on the town's overall percentage of minority or low-income residents. A poor and/or high minority town would need high tract numbers to qualify as certificate-concentrated in comparison to a richer and whiter town. In the latter type of town, a tract may not exceed a regional percentage but will easily exceed the town's percentage for race and/or income. While higher minority and/or poverty numbers can be a potential indicator of local-level segregation, it may also label an area as concentrated when the higher measurement is in fact an asset, not a problem. This definition is particularly problematic when it comes to racial concentration. Many households prefer racially diverse neighborhoods (Galster and Hill 1992, 274). Still others are more comfortable with neighborhoods predominantly of the same race (Chandler 1992, 286-289). In a town with an overall low percentage of minorities, the presence of higher levels of Black or Hispanic population in a particular tract can be an attraction. For instance, Manchester's overall minority population in 1990 was 8 percent. The tracts at 10,12 , and 17 percent qualify as concentrated according to HUD standards but may be desirable neighborhoods because of their higher numbers of people of color. Finally, and more importantly for this study, the HUD measurement, with its town-level focus, does nothing to address regional fair share concerns.

In order to account for these problems, a second definition of racial concentration was developed for use in this study. This other standard was 
designed to serve several purposes. First, it differs from the HUD town-based race constraint by using a regional standard to which all tracts are compared rather than rely one each town's own percentage. Second, as it is based on the number of certificates in any particular tract, it also serves to answer local concerns about the number of certificates in any one town rather than the racial/income breakdown. Third, because the analysis uses regional certificate standards, a regional fair share concept is maintained.

The first step for determining concentration in this latter measurement tool is to count the number of certificates in each census tract in the Capitol Region. The actual assignment of certificates per tracts became somewhat complicated by certificates located on the boundary between two tracts. After first establishing which certificates were so placed, these border certificates were proportionally distributed to each tract. While not an exact accounting, the author believes the estimate gives a fair portrayal of location.

To measure certificate concentration, it was determined that the regional percentage of tenant-based assisted units to all rental units was 6.78 percent. Any tract whose certificate to rental unit percentage exceeded the regional number was designated a high-certificate tract. This placed the emphasis on regional fair share. By using the regional percentage, the goal is to distribute certificates in the same proportion throughout the region. The drawback to this method comes from its reliance on rental units as the denominator. Areas which have large amounts of rental property are able to support larger numbers of certificate units before becoming concentrated. Therefore a town that, because of historical trends and/or 
present strategy, has few rental units will only need to maintain a few certificate units while towns like Manchester and East Hartford can support many more certificate units.

East Hartford is the classic example. It has the highest number of certificate units outside of Hartford, yet only four of its tracts meet the highcertificate definition. Tract 5104 has the most certificates in East Hartford, 102, yet its large number of rental units, 1754, prevent its naming has a high-certificate tract. Still, this measure does work to point out particularly concentrated tracts. A tract which has a large number of rental units and is also designated as a highcertificate tract (e.g. Enfield's 4806), becomes a strong indicator of certificate concentration (Appendix 4).

In the intra-town discussions, a non-regional description of the relationship

Primary Certificate Tract
A tract which, for the respective town, receives a
higher than town average of certificates. (Number
of certificates divided by tracts)
High Certificate Tract
A tract in which the certificate-to-rental unit ratio
exceeds the regional percentage of 6.78 .
of certificates and tracts had to be developed.

While regional comparisons are important, many local policy makers are concerned about the number of certificates in use in their particular town and how those certificates are distributed in the community. This study uses the terminology "primary certificate tract" to describe those tracts that exceed the respective town's average of certificates to tracts.

The next step was to account for the HUD town-based standard of race and income. To adjust for this, the study added a regionally oriented measure for each 
of these two categories. For racial concentration, if a tract exceeded 40 percent persons of color it qualified as a severely race-concentrated tract. The figure of 40 percent is the guide because the literature on racial concentration presents this as a minimum to be considered for a determination of racial segregation (Chandler 1992, 294).

Similarly, adjustments were made for economic concentration. The medium income for the region is $\$ 42,077$. However, several of the suburban towns have median incomes in the $\$ 50,000$ to $\$ 60,000$ range; 50 or 80 percent of these incomes, as the HUD standard mandates, is really not a low income. Furthermore, it was necessary to account for Hartford's impact on the percentage of poor

Regional Race Standard

Any tract that exceeded 40 percent persons of color.

Regional Income Standard

Any tract where the percentage of households earning less than $\$ 20,000$ exceeded 15.6 percent households on the regional median income. To establish the suburban percentage of households at the very-low income level, Hartford's tracts were excerpted from the

regional tally. With Hartford's tracts excluded, 15.6 percent of all households were below $\$ 20,000$ income, the amount that approximates 50 percent of the regional medium income. If a tract had more than 15.6 percent of households earning less than $\$ 20,000$, than it was labeled a poor, non-Hartford tract or economically concentrated by suburban standards.

Once these additional measurements were taken, a Chi-square test was employed to determine if there was a statistically significant association between high certificates and any of these four measurements (HUD race and income 
levels, severe race levels, and poor non-Hartford tracts). In a Chi-square test, the object is to compare the observed outcomes with the outcomes that one would expect if location was determined by random chance only. The null hypothesis is that location is randomly selected; to reject the null, the outcome must be unusual enough to persuade the researcher that it is unreasonable to attribute the deviations to chance alone. The statistical test for significance, or unreasonableness, is anything with less than a 10 percent probability that the results would occur if random selection were the only determining factor. For this study, the tests suggest a slight, non-random concentration of certificate holders in racially concentrated tracts and a more pronounced concentration of certificate holders in low-income tracts.

\section{Racial concentration}

\section{The regional level}

Chi-square tests revealed some tracts wherein the intersection of high certificate tracts and race and income levels are statistically significant; that is, this intersection is unlikely to occur by random chance alone. This is the most critical finding that comes from this study. Knowledge of those tracts that exceed concentration standards allows policy makers to investigate ways to deconcentrate these areas or, at a minimum, look for ways to prevent further concentration. The table below provides chi-square results. 
Table 9 Regional Chi-Square Results: Racial Concentration

\begin{tabular}{|c|c|c|c|c|}
\hline & \multicolumn{2}{|c|}{ High Certificate } & \multicolumn{2}{|c|}{ Low Certificate } \\
\hline & $\begin{array}{c}\text { Not } \\
\text { Concentrated }\end{array}$ & Concentrated & $\begin{array}{c}\text { Not } \\
\text { Concentrated }\end{array}$ & Concentrated \\
\hline $\begin{array}{l}\text { HUD } \\
\text { Concentrated }\end{array}$ & $13(15.7)$ & $13(10.3)$ & $71(68.3)$ & $42(44.7)$ \\
\hline $\begin{array}{l}\text { Regionally } \\
\text { Concentrated * }\end{array}$ & $23(25.3)$ & $3(.7)$ & $114(111.7)$ & $1(3.3)$ \\
\hline
\end{tabular}

*Indicates statistical significance

$x(): x=$ Actual outcome, ()$=$ Expected outcome with random selection.

Using the HUD standard does not establish any statistical significance for the results. Although there are a total of 55 tracts (the sum of both high and low certificate concentrated tracts) that are HUD concentrated, the intersection of race and number of certificates is no greater than that expected by random selection.

However, with the regional standard there is a statistical significance. The good news is that just four tracts fall into this category. If location relied solely on chance, than only .7 high certificate tracts would be located in areas exceeding 40 percent persons of color. These results show that three tracts are at this intersection. These three tracts are 4711 and 4712 in Bloomfield and 4738 in Windsor. With only three tracts, the region does not have a major problem, but these three need to be monitored and intervention considered. ${ }^{16}$ Ironically, Bloomfield is not even one of the primary towns and Windsor has the least number of certificates of the six primary towns. Neither of these towns has been at the forefront of the tenant-based assistance debate.

\footnotetext{
${ }^{16}$ As previously noted, neither Windsor or Vernon provided town data that could be mapped. Therefore, the information on these towns is incomplete. Even without town data, Windsor has two high-certificate tracts; town data (about 120 units) would only add to this concentration, not lessen it. Vernon, on the other hand, had about 280 town-based units that could not be mapped. Using only state and portability data, there are no high-certificate tracts in Vernon. The addition of town units could easily changed this outcome.
} 
The chi-square test does suggest a slight association between racial concentration and high numbers of certificates. However, it is a very small number and the results must be treated with caution.

\section{The town level}

Only West Hartford and Windsor show a statistically significant junction of high certificate tracts and racial concentration at the town level. The table below provides the cross-tabulation results for all the towns in the region. The columns indicate whether and how many of the towns' high and low certificate tracts also exceed HUD racial concentration standards. Details of certificate distribution are given in the section and maps following. Both the West Hartford and Windsor results give evidence of some statistically significant, non-random outcomes. While the results may suggest these two towns pay particular attention to their certificate programs, the other towns are not exempt from review. Every primary town has tracts with distress characteristics that also draw certificate households.

\begin{tabular}{|c|c|c|c|c|}
\hline \multirow[b]{2}{*}{ Munich palty } & \multicolumn{2}{|c|}{ High Certificate } & \multicolumn{2}{|c|}{ Low Certificate } \\
\hline & ooilontrat & Concentrated & $\begin{array}{l}\text { Not } \\
\text { Concontratod }\end{array}$ & 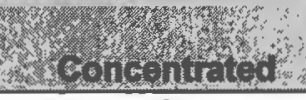 \\
\hline Andover & 0 & 0 & 1 & 0 \\
\hline Avon & 0 & 0 & 3 & 1 \\
\hline Bloomfield & 0 & 2 & 2 & 1 \\
\hline Bolton & 0 & 0 & 1 & 0 \\
\hline Canton & 0 & 0 & 1 & 1 \\
\hline East Granby & 0 & 0 & 1 & 0 \\
\hline East Hartford & 3 & 1 & 4 & 6 \\
\hline East Windsor & 0 & 0 & 1 & 1 \\
\hline Ellington & 0 & 0 & 1 & 1 \\
\hline
\end{tabular}


Table 10 Con't.

\begin{tabular}{|c|c|c|c|c|}
\hline \multirow[b]{2}{*}{ Municipality } & \multicolumn{2}{|c|}{ High Certificate } & \multicolumn{2}{|c|}{ Low Certificate } \\
\hline & $\begin{array}{c}\text { Not } \\
\text { Concentrated }\end{array}$ & Concentrated & $\begin{array}{c}\text { Not } \\
\text { Concentrated }\end{array}$ & Concentrated \\
\hline Enfield & 1 & 1 & 9 & 1 \\
\hline Farmington & 2 & 0 & 1 & 1 \\
\hline Glastonbury & 0 & 0 & 5 & 2 \\
\hline Granby & 0 & 0 & 1 & 1 \\
\hline Hartford & 0 & 0 & 0 & 0 \\
\hline Hebron & 0 & 0 & 1 & 0 \\
\hline Manchester & 5 & 2 & 2 & 4 \\
\hline Marlborough & 0 & 0 & 1 & 0 \\
\hline Newington & 0 & 0 & 3 & 4 \\
\hline Rocky Hill & 0 & 0 & 2 & 1 \\
\hline Simsbury & 0 & 0 & 1 & 1 \\
\hline Somers & 0 & 0 & 1 & 0 \\
\hline South Windsor & 0 & 0 & 1 & 1 \\
\hline Suffield & 0 & 0 & 2 & 1 \\
\hline Tolland & 0 & 0 & 1 & 1 \\
\hline Vernon & 0 & 0 & 5 & 2 \\
\hline West Hartford ${ }^{*}$ & 3 & 4 & 9 & 1 \\
\hline Wethersfield & 0 & 0 & 3 & 3 \\
\hline Windsor* & 0 & 2 & 5 & 1 \\
\hline Windsor Locks & 0 & 1 & 1 & 1 \\
\hline
\end{tabular}

\section{Primary towns}

\section{East Hartford}

East Hartford is one of the suburban towns with a high percentage of rental units to housing units; as of 1990,41 percent of the town's housing units were rental units. An initial glance at the map of East Hartford's tenant-based assistance shows that units appear clustered in certain tracts (Figure 17), although they are also distributed throughout the town. Most tracts have several hundred rental units except four that have fewer than 100 (Appendix 4).

Tenant-based assisted units utilize slightly over 7 percent of rental units town-wide compared with the regional 6.78 percent. Largely because of the townwide distribution and the high number of rental units, East Hartford has only four tracts that qualify as regional high certificate tracts even though it has the 
Figure 17 East Hartford Tenant-Based Rental Assistance

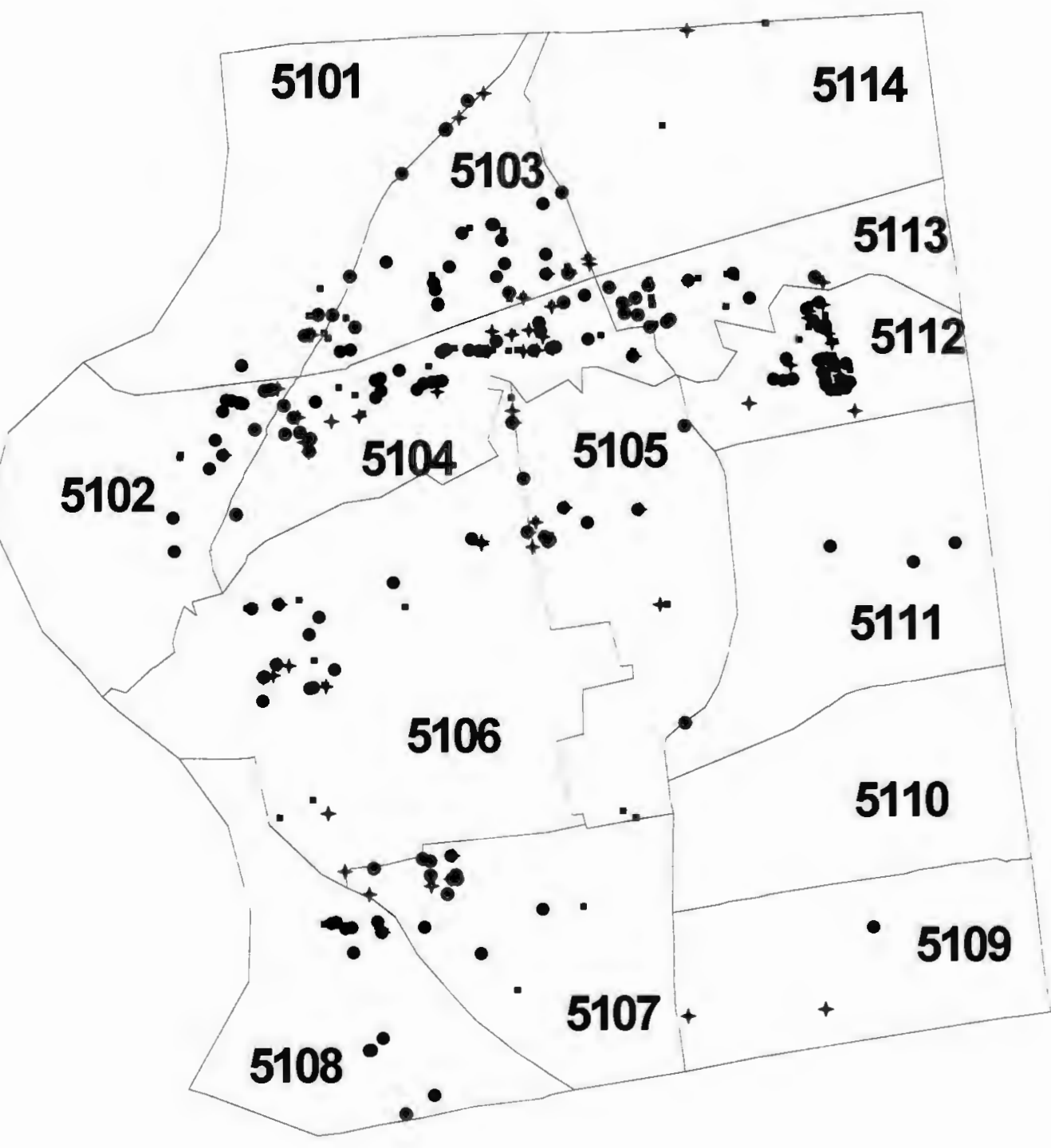

- Town orignated, town used

- Portable inbound

$+\quad$ State programs*

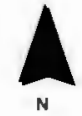

$\square$ Tract boundaries

* CRT provided total number of RAP certificates (74) but not locational information therefore these units are not mapped.

$\begin{array}{lll}0 & 1 & 2 \\ & \text { Miles }\end{array}$

Source: Certificates from East Hartford Authority, Imagineers, and CRT. Spring 1996. Boundaries from 1994 U.S. TIGER files. 
most certificate units of all suburban towns. Two tracts use much more than 7 percent of rental units for certificates, tracts 5112 and 5114 . Of these, 5114 has only seven certificate units; the percentage is so high because there are only 38 rental units in the entire tract. The other two high certificate tracts are 5101 and 5108. The remainder of the tracts range from 3.7 to 6.1 percent certificate except one; that exception being tract 5110 . Its rental units number only 47 of which none go for certificate units.

The percent minority for the town of East Hartford is 16.6. Four tracts in the town exceed this percentage by at least nine points (Appendix 5), which yields a percentage half again as great as the town percentage. These HUD raceconcentrated tracts are $5103,5104,5105$, and 5106 , all tracts that are at the center of East Hartford's certificate tracts. Two of these four, 5103 and 5106, are tracts with distress or poverty problems. Two other tracts $(5112,5113)$ exceed the HUD minority percentage by only a couple of points. According to the HUD standard, there is some cause for concern.

\section{Enfield}

Overall, 25 percent of Enfield's housing units are rental property, of which tenant-based assistance uses 4.8 percent. Though Enfield has fewer than 200 certificates in use in the town, based on the number rather than percentages of certificate units, it is one of the most concentrated of all towns. Over 130 of the units are located in tract 4806; no other tract has more than 13 certificate units (Figure 18). A major reason for this agglomeration is that tract 4806 has three times as many rental units as any other Enfield tract and is the only tract with 
greater than 10 percent increase in the amount of rental property between 1980 and 1990. Still two other tracts, 4808 and 4812 , have over 500 rental units but very few certificate units, particularly 4812 , which has only one certificate unit.

Only two tracts are high certificates tracts; the aforementioned tract 4806 is the highest at 8.2 percent, and 4813 registers 7.6 percent. The latter has only seven certificate units; with only 92 total rental units in the tract, a few looks like more.

Six percent of Enfield's population are minorities. Track 4806 exceeds this number by 2.5 points, a 41 percent greater minority population than in the town overall. This is a tract to be monitored. It is a distressed tract with a high number of certificates and it exceeds HUD minority percentages.

\section{Manchester}

Manchester is another high rental property town with 41 percent of its housing stock classified as rental units. Of these, tenant-based assisted units occupy 6.2 percent. Unlike East Hartford, which has the same percentage of rental property, Manchester has seven high-certificate tracts. Tracts classified as regional high-certificate tracts are $5143,5144,5145,5146,5148,5151.01$, and 5152 (Figure 19).

Manchester has three tracts that are just slightly over the town figure of 8 percent minority $(5141,5145,5146)$. In addition, three others have larger minority percentages. Tract 5142 has a 10.9 percent minority population. Tract 5147 is 12 percent minority, 50 percent more than the town percentage and the tract with the highest number of certificate units although still not a regional high-certificate tract. 
Figure 18 Enfield Tenant-Based Rental Assistance

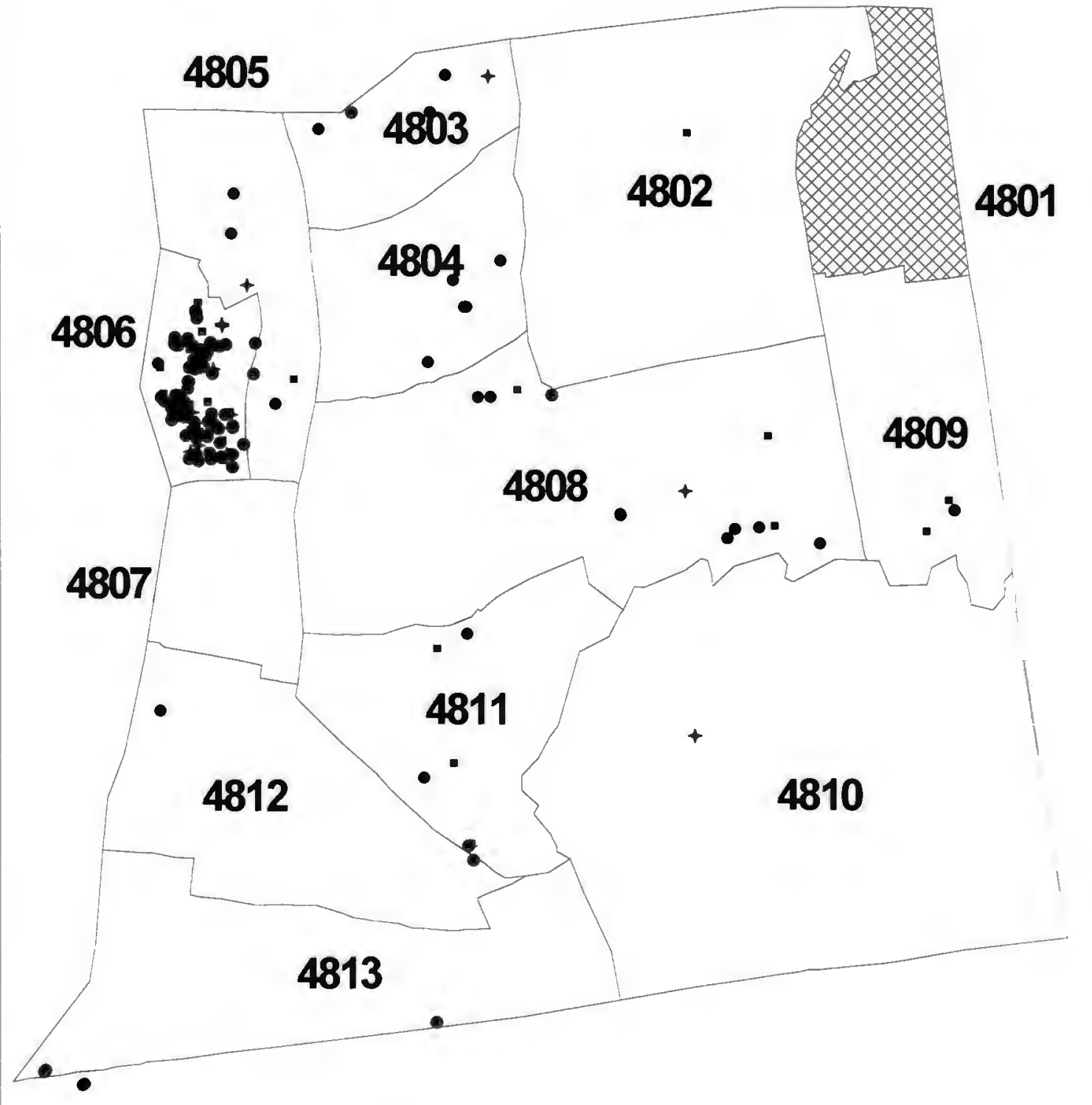

- Town originated, town used

+ State programs

- Portable inbound

Institutional tract

Tract boundaries

$\begin{array}{lll}0 & 1 & 2 \text { Mies }\end{array}$

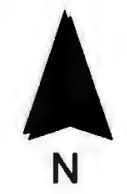

Source: Certificates from Enfield Housing Authority, Imagineers, CRT, and Hartconn, Spring, 1996. 1990 U.S. Census, STF1, Table P28. Boundaries from 1994 U.S. TIGER files. 
Figure 19 Manchester Tenant-Based Rental Assistance

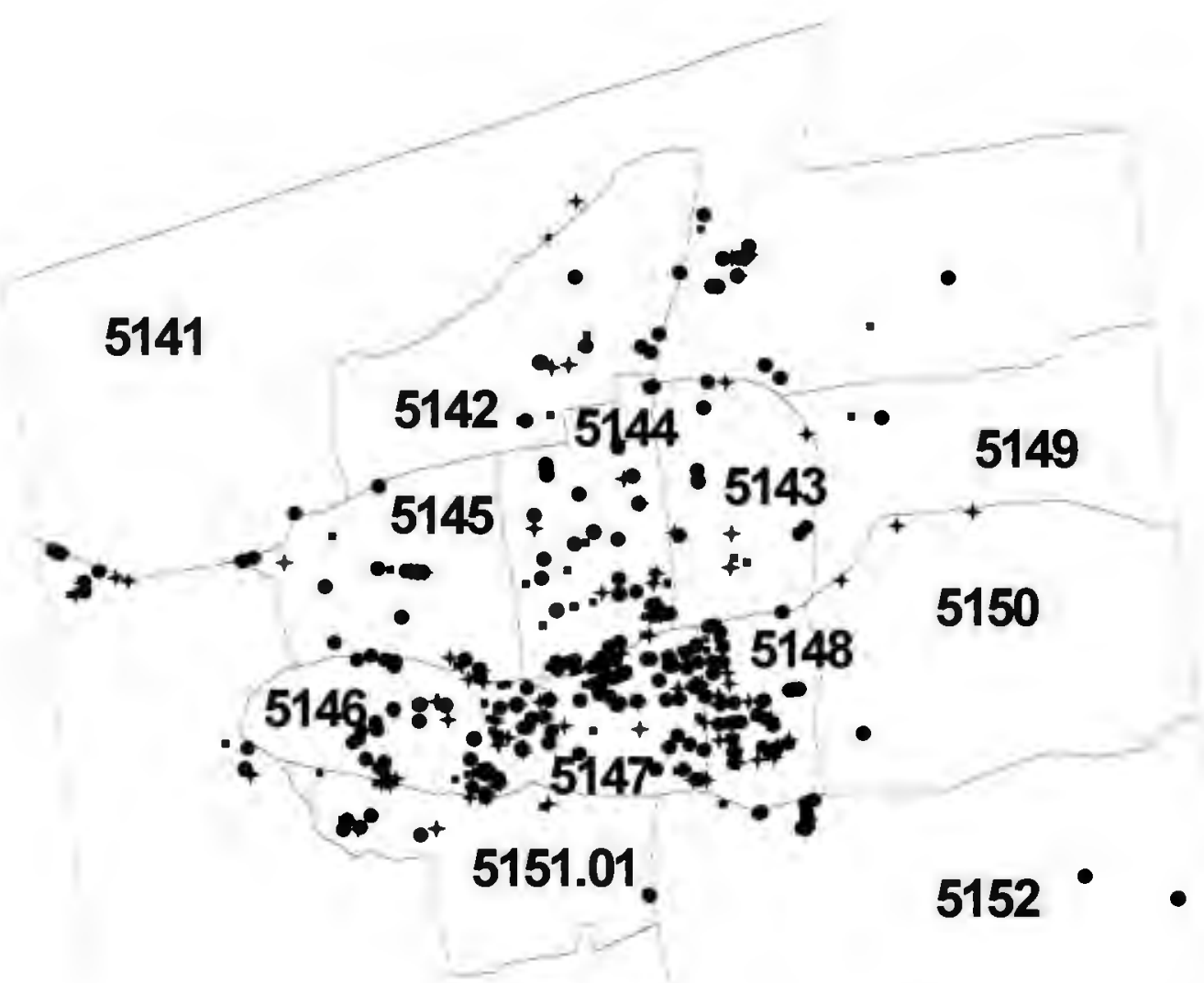

5151.02

- Town originated, town used

+ State programs

- Portable inbound

Tract boundaries

Source: Manchester Housing Authority,

East Hartford Housing Authority, Imagineers, CRT, and Hartconn, Spring 1996.

Boundaries from 1994 U.S. TTGER files. 
At 17.5 percent minority tract 5151.02 is Manchester's most race-concentrated tract but it is not a primary certificate tract. In fact, none of the three top minority tracts exceed regional high certificate levels.

West Hartford

The final primary town to be examined closely is West Hartford. The town has 27 percent of its housing stock in rental properties, considerably lower than the towns of East Hartford and Manchester. Of these, tenant-based assisted units comprise 8.1 percent. There are seven regional high certificate tracts: 4961 (at 18.7 percent), 4963 (10.8), 4964 (8.8), 4967 (9.5), 4968 (10.8), 4969 (8.4), and 4971 (7.7) (Figure 20).

This town has 8.2 percent minority population. One tract that stands out as a highly race-concentrated tract is 4961 , with a 33.7 percent minority population. Tracts 4967, 4968, and 4969 also have minority populations in excess of 12 percent; all four of these tracts border Hartford and are high-certificate tracts. The four racially concentrated tracts also draw certificate households in large numbers. But is this significant? That is what a chi-square test will reveal.

These same four tracts do lead to a rejection of the null hypothesis, the first one at the town-level of analysis. The null hypothesis states that location is randomly selected; to reject the null, the outcome must be unusual enough to assume that deviations to cannot be attributed to chance alone. A closer examination of the certificate practices are warranted here. 
Figure 20 West Hartford Tenant-Based Rental Assistance

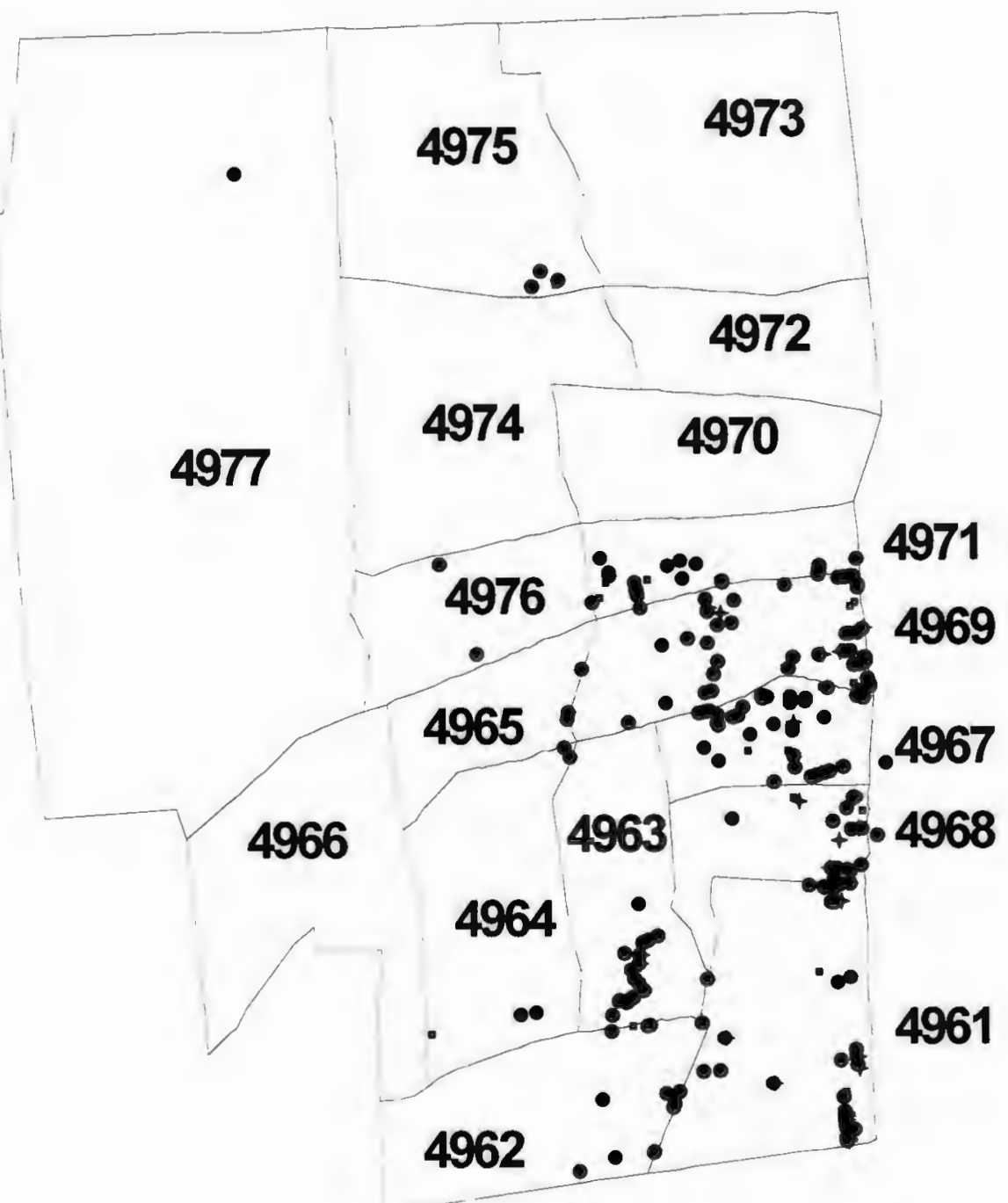

- Town originated, town used

+ State programs

- Portable inbound

Tract boundaries

Source: West Hartford Housing Authority, Imagineers, CRT, and Hartoonn, Spring 1996. Boundaries from 1994 U.S. TIGER files. 


\section{Windsor and Vernon}

Because of a lack of access to town-level certificate data in the final two towns of this category, certificate concentration could not be accurately measured. Still, based on just the location of state and Mobility data, some observations can be made. The town of Windsor is the only town of the six primary towns to have a tract with a greater than 40 percent minority population. That tract is 4738 . The town also fails chi-square test for both levels of racial concentration, HUD and severe. Based on chance, the expectation is that .8 tract would be both high certificate and concentrated; this town has two tracts that fall into this category. However, with so few cases, the true importance of this result is undetermined.

Without town-based certificate data, Vernon has no high-certificate tracts, although this would change with the addition of town data. One tract does meet the HUD standard of racially concentration, 5302. This tract has already proven to draw large numbers of certificate househoids. If town level data were added to the analysis, this tract would very likely be an area of certificate concentration.

\section{Secondary Towns}

These towns include Farmington, Glastonbury, Newington, South Windsor, Wethersfield, Bloomfield, and Windsor Locks. No town in this group has more than 27 percent of total housing stock in rental property. All but Windsor Locks (at 6.4 percent) have fewer than 4 percent of their rental properties going to tenantbased rental assistance. Only four tracts in this category of towns qualify as regional high certificate tracts. For some the percentage is misleading, as in the case of tract 4601 in Farmington, which uses 19.6 of its rental units for certificate 
units. However, there are only 56 rental units in the tract and 11 of these are for certificates. This town is also making creative use of the downturn in the condominium market by placing rental-assisted tenants in these empty condos. So while the numbers may indicate concentration, the actual program is offering opportunities previously unavailable to low-income families.

Two other high certificate tracts are 4711 and 4712 of Bloomfield, previously identified as racially concentrated. The overall Bloomfield certificate percentage is 4.38 ; these tracts are 20.5 and 12.9 percent certificate-holding respectively. The last high certificate tract is 4761 of Windsor Locks.

If Bloomfield is excepted, only two tracts in this group of towns can be HUDdefined as racially concentrated. They are tract 5203 in Glastonbury and tract 4923 in Wethersfield. The Glastonbury tract is the primary certificate tract in that town although still not a high certificate tract. The one in Wethersfield borders Hartford. Bloomfield has three highly racially concentrated tracts, 4711,4712 , and 4715 , though because the town itself has a 45.7 percent minority population, tract 4715 is not much over this percentage. The first two border Hartford and are regional high certificate tracts.

\section{Tertiary Towns}

The amount of rental property each of these town has ranges from as little as 9 percent in Tolland to as much as 38 percent in East Windsor. All towns have less than one percent of rental property used for tenant-based assistance except 
Andover which has about 2 percent. None of the tracts in this last cluster is racially concentrated.

\section{Economic concentration}

\section{The regional level}

The chi-square analysis for economic concentration reveals several tracts that show a connection between high certificate use and low incomes. Whether the HUD or the regional standard is used, the same 17 high certificate tracts show statistical significance at the regional level. The probability that this would occur randomly is less than one percent in both measurements (Table 11). The 17 tracts are:

$\begin{array}{ll}\text { Bloomfield } & 4712 \\ \text { East Hartford } & 5101,5108.5112 \\ \text { Enfield } & 4806 \\ \text { Manchester } & 5143,5144,5146,5148 \\ \text { West Hartford } & 4961,4963,4967,4968,4969,4971 \\ \text { Windsor } & 4738 \\ \text { Windsor Locks } & 4761\end{array}$

Table 11 Regional Chi-Square Results: Economic Concentration High Certificate Low Certificate Not Concentrated Not Concentrated

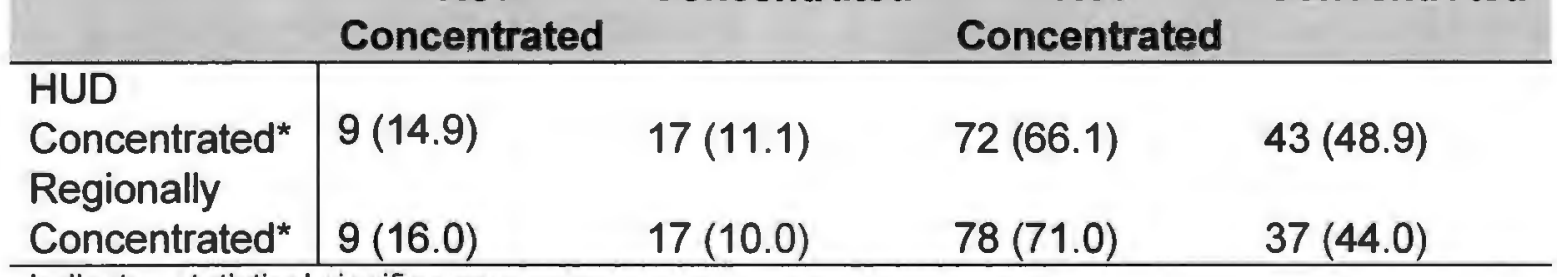

Indicates statistical significance;

$x(): x=$ Actual outcome; ()$=$ Expected outcome with random selection.

While these 17 tracts need to be examined, of greater interest are the nine high certificate tracts that do not coincide with economically concentrated tracts.

This is an outcome sought in portability programs: to have certificate users live in 
less class-segregated areas where the diversity of experiences can favorably impact lives, present and future. These areas need to be studied to see what it is about them that welcomes low-income residents but does not segregate, intentionally or inadvertently, by income level. These nine tracts are:

$\begin{array}{ll}\text { Farmington } & 4601 \\ \text { Bloomfield } & 4711 \\ \text { Windsor } & 4731 \\ \text { Enfield } & 4813 \\ \text { West Hartford } & 4964 \\ \text { East Hartford } & 5114 \\ \text { Manchester } & 5145,5151.01,5152\end{array}$

\section{The town level}

The remainder of the economic concentration section reports on those tracts that HUD would identify as income-concentrated. For details, refer to Appendix 6.

\section{Primary towns}

East Hartford has the second lowest median income in the region; only tract 5106 exceeds the town economic concentration standards at both very low and low income levels. The only other tracts that exceed the town statistics by ten points or more at either income level are 5102 (at 50 percent) and 5104 (at 80 percent). In Enfield, economic concentration is much more of a factor than racial concentration. Three tracts, 4805,4806 , and 4607 , are more than ten points higher than the town percentages for very low and low income populations.

In Manchester, tracts 5146 and 5147 both exceed the town figures. These are the two top sites for number of certificate users and surpass town percentages 
by just over ten points in each category. Another tract that shows up in the HUD measurement is tract 5142 , which exceeds the town's very low income concentration. In West Hartford, the same four tracts with HUD racial concentration are also economically concentrated $(4961,4967,4968$, and 4969$)$. And tract 4971, another border tract with a high number of certificates, is just about at the town percentage of very low income population but has half of its population below 80 percent of median income. Of the remaining two primary towns, Windsor has three HUD income-concentrated tracts $(4734,4737,4738)$, two of which exceed the standard by 10 points or more. Vernon has two HUD incomeconcentrated tracts $(5301,5302)$.

\section{Secondary Towns}

Both 4713 and 4715 in Bloomfield qualify for economic concentration at the very low income level. For economic concentration in the other towns in this category, more tracts are economically concentrated than are racially concentrated. This includes Glastonbury's tract 5203, tract 4761 in Windsor Locks (a primary certificate tract), tract 4944 in Newington, and South Windsor's tract 4875.

\section{Tertiary Towns}

In all these towns, only two tracts are economically concentrated. The first, Canton's tract 4641.02 , is one of only two in the town and the location for all of Canton's rental assistance certificates. However, "all" here is only 19 certificates, less than 3 percent of all the rental property in the town. The other tract is in 
Simsbury, tract 4664 . However, with a town median income of over $\$ 64,000$, this is a misleading designation. Fifty percent of the town's median income is only $\$ 10,000$ less than the regional median income of $\$ 42,077$, and $\$ 10,000$ more than the median income of Hartford. Even though this tract exceeds the town percentages for population at 50 and 80 percent of median income, to call this population "low or very low income" is a misnomer.

\section{Summary}

Overall, tracts that had previously been spotlighted as potential for distress problems also showed signs of race and income concentration. Regionwide, however, the issue is at an early stage so that intervention now by policy makers could deter more serious future problems. Although all of the primary towns have concentrated tracts, the number is small in each town. In these six towns, the tracts in the list below warrant the most concern.

\begin{tabular}{llll} 
Town & Tract & $\frac{\text { Town }}{\text { Tract }}$ \\
\hline East Hartford & 5103,5106 & Vernon & 5302 \\
Enfield & 4806 & Windsor & 4738 \\
West Hartford & $4961,4967,4968,4969$ & Manchester & 5147
\end{tabular}

The definition of concentration is key to determining whether intervention is necessary. As this chapter describes, what may meet one definition may in fact counter efforts at greater diversity. And meeting a definition may not imply that the outcome is anything more than random selection. These results do identify tracts that require additional study and possible action, one of the recommendations offered in the final chapter. 


\section{CHAPTER SIX: CONCLUSIONS}

Although this report has explored a number of tenant-based assisted housing issues, the study of certificate households and location is not complete. The examination and analysis done for this report begins to look at the outcomes of a program that has considerable potential to impact individual lives and the quality of living. This final chapter reviews the results of the study, makes recommendations, and lists areas for future investigation.

\section{Regional results}

There are several ways the conclusions of this study classify the Capitol Region tenant-based housing assistance program as a regional success. And still, as with most programs, there is room for improvement.

First, the certificate program in general, and the portability aspects in particular, succeed in providing more and better affordable housing options for people in the Capitol Region. The Hartford Mobility analysis indicates that households relying on certificates do utilize portability to move to more favorable areas. But the program benefit it is not solely that people are moving from areas of distress. Tenant-based assistance simply allows low-income households to choose a home in the much same way as those with fewer income restrictions do: by exploring the market for a location that suits the household. Unfortunately, the federal government is lowering the fair market rent, the highest rent a landowner can charge and still have the unit eligible to a certificate-assisted household. 
Although this will in turn reduce available rental selections, at least these households are not constrained to a particular locations as with project-based assistance.

Second, despite the fact that this study confirmed regional concentration, it did not indicate a major regional problem as yet. There are high certificate tracts with distress characteristics as well as race and income concentration that need attention. But the environment from which some of the portable certificate households moved are severely distressed. The concentration results turned up here are not a sign of program failure. Some towns may have more pronounced local problems, but concentration standards need to be balanced with diversity goals. Blanket assumptions of negative qualities are not justified, as this analysis shows.

Third, the inner rings of towns around Hartford still bear the heaviest use of the certificate program. Yet the comparison of the 1992 and 1996 Hartford Mobility program shows signs of increasing dispersion. Households are choosing a wider variety of tracts than just four years ago. Policy makers must look for ways to quicken this process and monitor towns like East Hartford so that regional inequity is minimized. Furthermore, the experience and evidence in West Hartford suggests that opting out of the Mobility Program prevents the program from reaching its potential.

Fourth, throughout the region, unconcentrated tracts have desirable rental characteristics. This holds true even in the primary towns. Certainly barriers to occupancy exist other than those based on rental property characteristics. But this 
report, with its focus of rental characteristics, reveals two things. First, opportunities for wider location choice extend from the more rural areas to the more populated towns. Second, the key housing characteristic is the amount of rental property. If the government turns to a market-based provision of assisted rental housing, then steps need to be taken to assure the adequate provision and distribution of rental property.

\section{Town results}

This section reviews town-specific observations for the primary towns. It brings together indices and indicators of desirability, distress, concentration, and standards covered in the report in a summary paragraph for town policy makers consideration.

\section{East Hartford}

As the chapter on census data conveyed, East Hartford possesses many of the desirable characteristics upon which a rental-assistance program relies: a large amount of rental units, low rent prices, and vacancies. A comparison of the rental opportunities map and certificate map for East Hartford (pages 77 and 103) confirms a strong correspondence between tracts with certificates and tracts above the regional mean for rental characteristics. The study identified four tracts as high desirability rental tracts: $5102,5103,5104$, and 5112 . The latter three of these are the tracts with the greatest absolute number of certificates in East Hartford although only tract 5112 meets the regional high-certificate standard. 
Tract 5103 is of questionable opportunity because of its "warning" label on the neighborhood distress indicator and the worsening of conditions in this tract between 1980 and 1990. Conversely, at just 3.7 percent certificates to rental units, tract 5102 is under-utilized. It has over 650 rental units, is not racially or economically concentrated by any standard, and is in the top of the desirable neighborhood indicator. The town offers other opportunities as well. Tracts 5101, 5107,5108 , and 5111 possess either vacancy or affordability characteristics. However, tracts 5101 and 5108 are already regional high-certificate locations. Though the town does not face strong concentration problems, efforts focused in the other tracts could result in improved certificate distribution.

Although tracts $5101,5108,5112$, and 5114 are designated regional highcertificate tracts, overall town level race and income concentration problems either do not exist or are relatively minor. Only tract 5104 exceeds both race and income concentration standards; tract 5105 is race-concentrated and 5102 incomeconcentrated. The two most problematic tracts in East Hartford are 5103 and 5106, which, while not regional high certificate tracts, are town primary certificate tracts. The problems arise from these two tracts' distress qualities; they also slightly exceed HUD race standards. East Hartford policy makers should examine these tracts most closely.

\section{Enfield}

Enfield too has areas of opportunity (page 72). Tracts 4805 and 4807 both are regionally ranked for rental affordability and 4807 for amount of rental property as well. Both do meet the HUD definition of an economically concentrated tract 
but they are not high-certificate tracts. Currently 4807 has no certificate units and 4805 only eight. While income segregation needs to be avoided, these tracts may still offer some options. And, though not regionally ranked for affordability, three other tracts, 4808,4809 , and 4810 , did show an increase in the number of affordable units between 1980 and 1990 . Certainly the local housing authority can use tracts 4808 and 4812 as a location choice. Each has over 500 rental units (more than 12 percent of all housing units). Finally, why tract 4806 contains almost 40 percent of all town rental units should be examined. This is a regional high-certificate tract which exceeds HUD's race and income standards. By utilizing some the non-concentrated tracts, Enfield could provide wider choices for current certificate households. However, marked improvement won't occur in the future without changes in the rental property dispersion.

\section{Manchester}

A comparison of rental-assisted units with the rental characteristics maps shows a high degree of correspondence between the two (pages 78 and 105). Most of the tracts with high numbers of certificate units rank above the regional mean for the amount of rental property.

Manchester is the only town with certificate units in every tract. Though two tracts have fewer than five, all other tracts have a least 20. Of the four Manchester tracts with the greatest number of rental units, two are also regional high-certificate tracts $(5144,5146)$. The fourth tract, 5151.02 , has over 900 rental units but only 21 certificate units. This same tract has already been designated as an area with potential for increasing certificate household choice based on rental desirability 
characteristics. It is also the most race-concentrated tract by HUD standards, though this study suggests there are limitations to HUD's standards. Another tract that offers opportunity is $\mathbf{5 1 4 2}$. At present, it is regionally ranked for amount of rental property and has only 3.7 percent of rental property used for certificates. But it too exceeds HUD's concentration guidelines, although by not as much as 5147. Considering both race and income concentration, the most HUD concentrated tract is 5147 but 5142 falls into both categories as well; neither is a regional high-certificate tract.

\section{West Hartford}

In this town, four high-certificate tracts meet all concentration definitions: 4961, 4967, 4968, and 4969. West Hartford shows the greatest degree of race, income, and certificate segregation of the six primary towns.

Again, a comparison of rental characteristics with tenant-assisted units shows a strong correlation between the amount of rental property and tenantbased assistance units (pages 79 and 107). The four tracts with the highest number of certificate units are also the only four tracts ranked for amount of rental property $(4961,4967,4969,4971)$. Of the five tracts without any certificates, only one has any of the rental characteristics. The tracts with a small number of certificates also possess very few rental characteristics. This town's opportunities are somewhat restricted, but that does not need to be an excuse for concentration. Even some of the most limited tracts offer some options; options that may make a big difference. 
Vemon

This study identified tract 5302 as a "watch" tract, but one that had improved over the decade in both public assistance and unemployment. In addition, every town tract but one (5303.02) possesses rental characteristics with 5303.01 and 5304 having the important amount-of-rental-property characteristic.

\section{Windsor}

This town has two tracts above the regional mean for amount of rental housing $(4734,4736.02)$. Other tracts have one or another of the desirability characteristics. Yet the tract, 4738 , with the most certificates has none and it exceeds race and income standards. Again, it is a town that needs to examine why location is so concentrated when other opportunities are available.

\section{Recommendations}

The following recommendations derived from this study provide direction for policy makers, both geographically and in policy. Affordable housing will continue to be a regional and town issue for the foreseeable future. Tenantbased rental programs, with their emphasis on flexibility, individual choice and responsibility, and public / private partnerships, capture many of the qualities sought in policy today. Support for tenant-based assistance will not only yield a better program, it has the potential to improve the quality of community life. 


\section{All towns must use the Hartford Special Mobility Program as designed.}

There may be ways to enhance and improve the program, but not using it makes social equity even more unattainable. This study identifies neighborhoods that housing counselors can explore to provide additional choices to certificate households. Limiting new moves into already congested areas will be more difficult but necessary.

The amount of rental housing proved key in attracting certificate households.

There are a variety of ways that zoning and land use requirements can encourage better distribution of rental units. In some areas, allowing accessory apartments may help both property owners and renters. In others, allowing for some increase in density may encourage development of a variety of units. While community experts hold owner-occupancy as an integral element in stable neighborhoods, a mixture of rental and owner properties can achieve similar stability effects with more significant diversity outcomes.

Knowledge of availability and opportunities can improve distribution.

This purpose of this report is to provide wider knowledge of the location of affordable rental dwellings. Local policy-makers must now work with HUD and local housing authorities to further identify more specific streets and census blocks of opportunity.

Areas that are now concentrated need attention.

Housing authorities need, at a minimum, to monitor those areas identified in this report as concentrated. Further steps can include working with certificate households in these areas to determine if other locations may be of interest. 
Furthermore, aside from housing, those areas that have distress characteristics need broader efforts. Job counseling, flexible day care, and dropout prevention will all deal with some of the area characteristics that limit all households' quality of life.

\section{Areas for future study}

This study provides the beginnings of a more far reaching study done in greater depth. Some of that additional areas for research on tenant-based assistance are listed below.

\section{A survey of certificate households.}

We do not know enough about why people make the location choices they do. An earlier survey studied solely Hartford residents, and that was before the advent of the Mobility Program (Donovan 1993). Advocates used that survey to determine demand for a mobility program. Now a follow-up survey is needed of those households that used certificates to move from one town to another. The survey should not be limited to Hartford Special Mobility participants; instead it should attempt to reach households that move from town to town in the regular portability program as well. Questions should explore reasons for moving, barriers, and the level of knowledge households had regarding the extent of their options. In particular, households in concentrated and unconcentrated tracts should be surveyed to determine why these tracts were chosen. Measuring changes in destination neighborhoods. 
Researchers need to develop reliable and accessible indicators that do not rely only on the U.S. census. The ten year time frame of the U.S. census does not work well when more immediate measurements are desired. Furthermore, the U.S. census is not designed to assess neighborhood quality of life questions. Possible sources for these indicators are: vacancy rates, housing code violations, demands on social services, race / income diversity levels, help wanted advertisements, school enrollment, vibrancy of community (voter registration and participation, active street life).

An examination of the nexus of transportation, jobs, and certificate use.

It is not just availability of housing that drives dwelling location choice. This study uses a geographic information system to map location and overlay this data with rental desirability and neighborhood distress characteristics. The next step would be to add public transportation routes and job data to the overlays. This would give a more complete picture of location choice and motivation impacts.

\section{Research limitations and advances}

There is always reason for the reader to exercise caution with any study. In this case, the reasons are the study's reliance on 1990 census data, the dynamic nature of the certificate population, the potential for some mapping errors, and the impacts of other factors on location decisions. Previous sections 
of this report expand on these limitations; the list here serves to remind the reader once again as the report comes to a close.

Despite cautionary statements, this study did proved fruitful on a number of levels. While more work needs to be done, there is enough in this analysis to reach some comfortable conclusions and give guidance to local and regional policy makers. Furthermore, it provides both methodological and substantive advances to research. Methodologically, the matching of geographic information system technology with social indicators is a relative new research tactic. As both the range of computer mapping and the development of social indicators grows, this method will allow researchers to see the world in a variety of ways.

Substantively, this study's combination of regional and town-based concerns balances the concept of regional fair share with local needs.

Generally, tension arises when trying to bring these two concepts together. The reporting in this study measured concentration from both perspectives and made recommendations for both levels of governance.

Tenant-based rental assistance is an important government program: Important for the households that need it to get by, important for regional equity, and important for cities and towns. With the addition of the information provided in this report, we owe it to ourselves and our communities to do what can be done to enhance the program. 


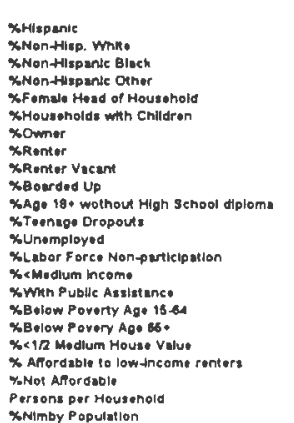

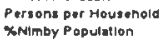

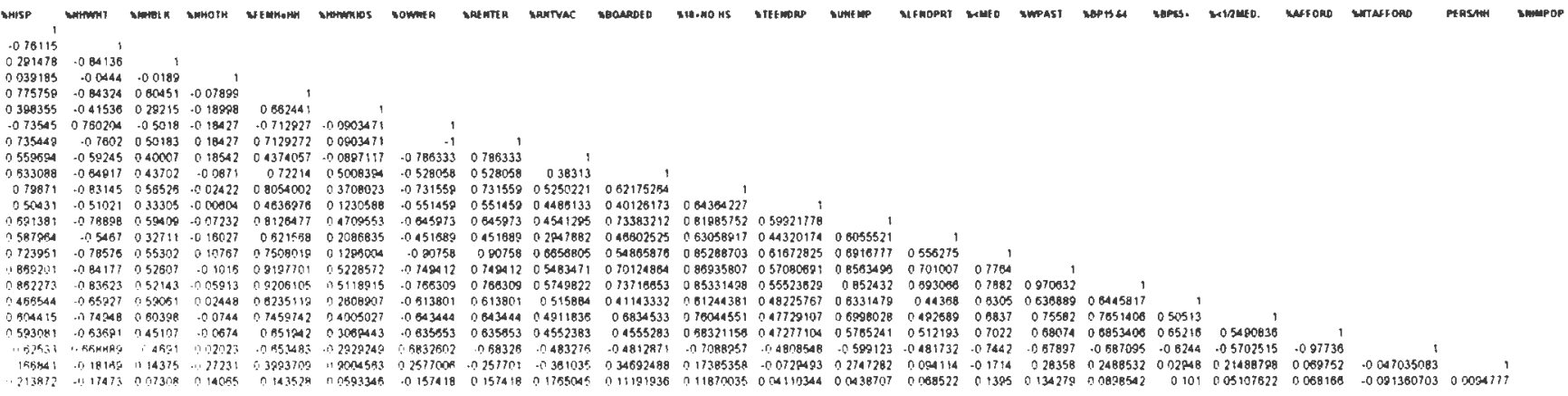




\section{APPENDIX 2}

Capitol Region Rankings

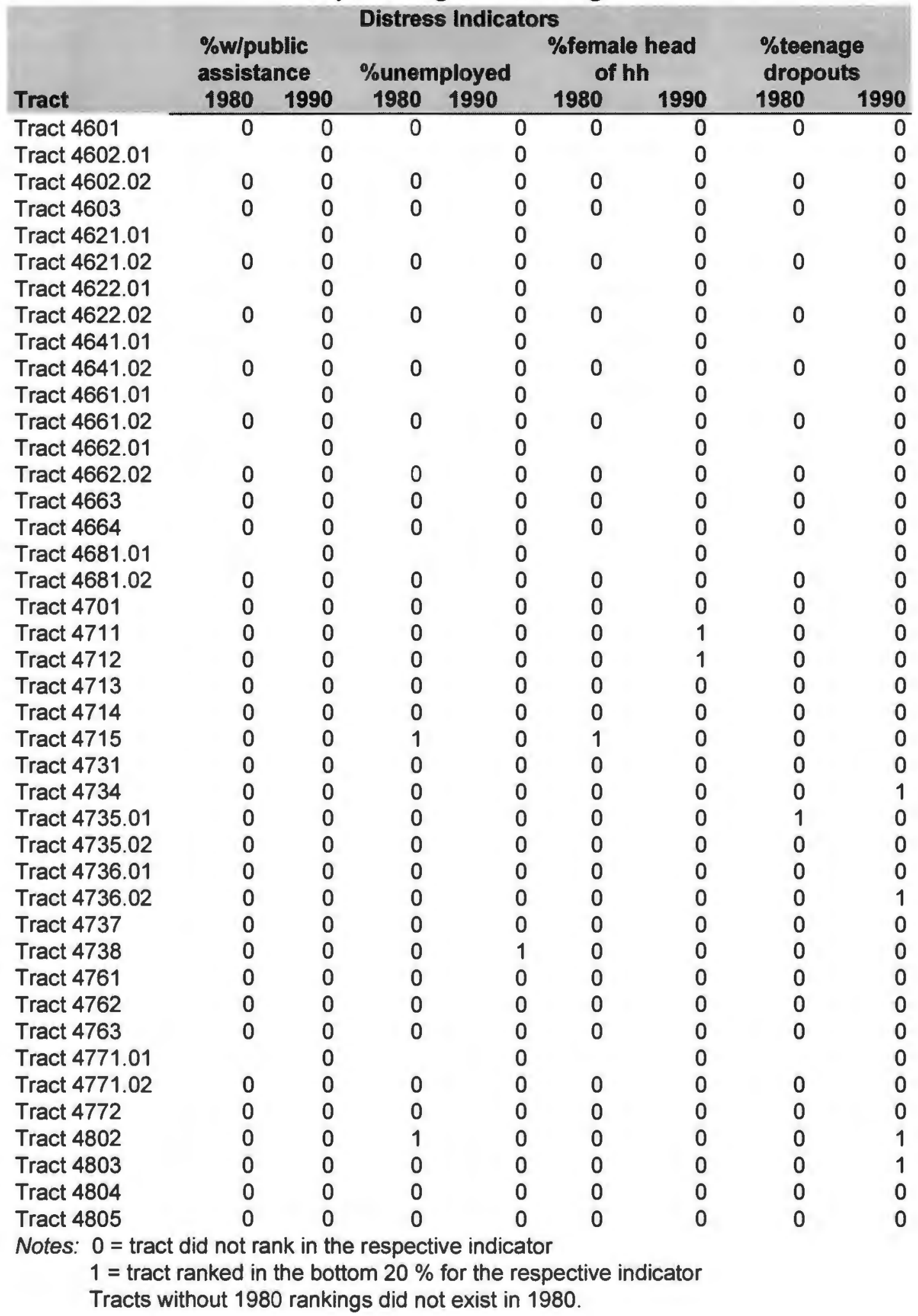




\begin{tabular}{|c|c|c|c|c|c|c|c|c|}
\hline \multirow[b]{3}{*}{ Tract } & \multicolumn{6}{|c|}{ Distress Indicators } & \multirow{2}{*}{\multicolumn{2}{|c|}{$\begin{array}{l}\text { \%teenage } \\
\text { dropouts }\end{array}$}} \\
\hline & \multicolumn{2}{|c|}{$\begin{array}{l}\text { \%w/public } \\
\text { assistance }\end{array}$} & \multicolumn{2}{|c|}{ \%unemployed } & \multicolumn{2}{|c|}{$\begin{array}{c}\text { \% female head } \\
\text { of hh }\end{array}$} & & \\
\hline & 1980 & 1990 & 1980 & 1990 & 1980 & 1990 & 1980 & 1990 \\
\hline Tract 4806 & 1 & 1 & 1 & 0 & 1 & 1 & 0 & 1 \\
\hline Tract 4807 & 0 & 0 & 0 & 0 & 0 & 0 & 0 & 0 \\
\hline Tract 4808 & 0 & 0 & 0 & 0 & 0 & 0 & 0 & 0 \\
\hline Tract 4809 & 0 & 0 & 0 & 0 & 0 & 0 & 1 & 0 \\
\hline Tract 4810 & 0 & 0 & 0 & 0 & 0 & 0 & 0 & 0 \\
\hline Tract 4811 & 0 & 0 & 0 & 0 & 0 & 0 & 0 & 0 \\
\hline Tract 4812 & 0 & 0 & 0 & 0 & 0 & 0 & 0 & 0 \\
\hline Tract 4813 & 0 & 0 & 0 & 0 & 0 & 0 & 0 & 0 \\
\hline Tract 4841 & 0 & 0 & 0 & 0 & 0 & 0 & 0 & 0 \\
\hline Tract 4842 & 0 & 0 & 0 & 0 & 0 & 0 & 0 & 0 \\
\hline Tract 4871 & 0 & 0 & 0 & 0 & 0 & 0 & 0 & 0 \\
\hline Tract 4872 & 0 & 0 & 0 & 0 & 0 & 0 & 0 & 0 \\
\hline Tract 4873 & 0 & 0 & 1 & 0 & 0 & 0 & 0 & 0 \\
\hline Tract 4874 & 0 & 0 & 1 & 0 & 0 & 0 & 0 & 0 \\
\hline Tract 4875 & 0 & 0 & 0 & 0 & 0 & 0 & 0 & 0 \\
\hline Tract 4901 & 0 & 0 & 0 & 0 & 0 & 0 & 0 & 0 \\
\hline Tract 4903.01 & & 0 & & 0 & & 0 & & 0 \\
\hline Tract 4903.02 & 0 & 0 & 0 & 0 & 0 & 0 & 0 & 0 \\
\hline Tract 4921 & 0 & 0 & 0 & 0 & 0 & 0 & 0 & 0 \\
\hline Tract 4922 & 0 & 0 & 0 & 0 & 0 & 0 & 0 & 1 \\
\hline Tract 4923 & 0 & 0 & 0 & 0 & 0 & 0 & 0 & 0 \\
\hline Tract 4924 & 0 & 0 & 0 & 0 & 0 & 0 & 0 & 0 \\
\hline Tract 4925 & 0 & 0 & 0 & 0 & 0 & 0 & 0 & 0 \\
\hline Tract 4926 & 0 & 0 & 0 & 0 & 0 & 0 & 0 & 0 \\
\hline Tract 4941 & 0 & 0 & 0 & 0 & 0 & 0 & 0 & 0 \\
\hline Tract 4942.01 & & 0 & & 0 & & 0 & & 0 \\
\hline Tract 4942.02 & 0 & 0 & 0 & 0 & 0 & 0 & 0 & 0 \\
\hline Tract 4943 & 0 & 0 & 0 & 0 & 0 & 0 & 0 & 0 \\
\hline Tract 4944 & 0 & 0 & 0 & 0 & 0 & 0 & 0 & 0 \\
\hline Tract 4945 & 0 & 0 & 0 & 0 & 0 & 0 & 0 & 0 \\
\hline Tract 4946 & 0 & 0 & 0 & 0 & 0 & 0 & 0 & 0 \\
\hline Tract 4961 & 1 & 0 & 0 & 0 & 0 & 0 & 0 & 0 \\
\hline Tract 4962 & 0 & 0 & 0 & 0 & 0 & 0 & 0 & 0 \\
\hline Tract 4963 & 0 & 0 & 0 & 0 & 0 & 0 & 0 & 0 \\
\hline Tract 4964 & 0 & 0 & 0 & 0 & 0 & 0 & 0 & 0 \\
\hline Tract 4965 & 0 & 0 & 0 & 0 & 0 & 0 & 0 & 0 \\
\hline Tract 4966 & 0 & 0 & 0 & 0 & 0 & 0 & 0 & 0 \\
\hline Tract 4967 & 0 & 0 & 0 & 0 & 0 & 0 & 0 & 0 \\
\hline Tract 4968 & 0 & 0 & 0 & 0 & 0 & 0 & 0 & 0 \\
\hline Tract 4969 & 0 & 0 & 0 & 0 & 0 & 0 & 0 & 0 \\
\hline Tract 4970 & 0 & 0 & 0 & 0 & 0 & 0 & 0 & 0 \\
\hline Tract 4971 & 0 & 0 & 0 & 0 & 0 & 0 & 0 & 0 \\
\hline Tract 4972 & 0 & 0 & 0 & 0 & 0 & 0 & 0 & 0 \\
\hline Tract 4973 & 0 & 0 & 0 & 1 & 0 & 0 & 0 & 0 \\
\hline Tract 4974 & 0 & 0 & 0 & 0 & 0 & 0 & 0 & 0 \\
\hline Notes: & & & & & & & & \\
\hline
\end{tabular}




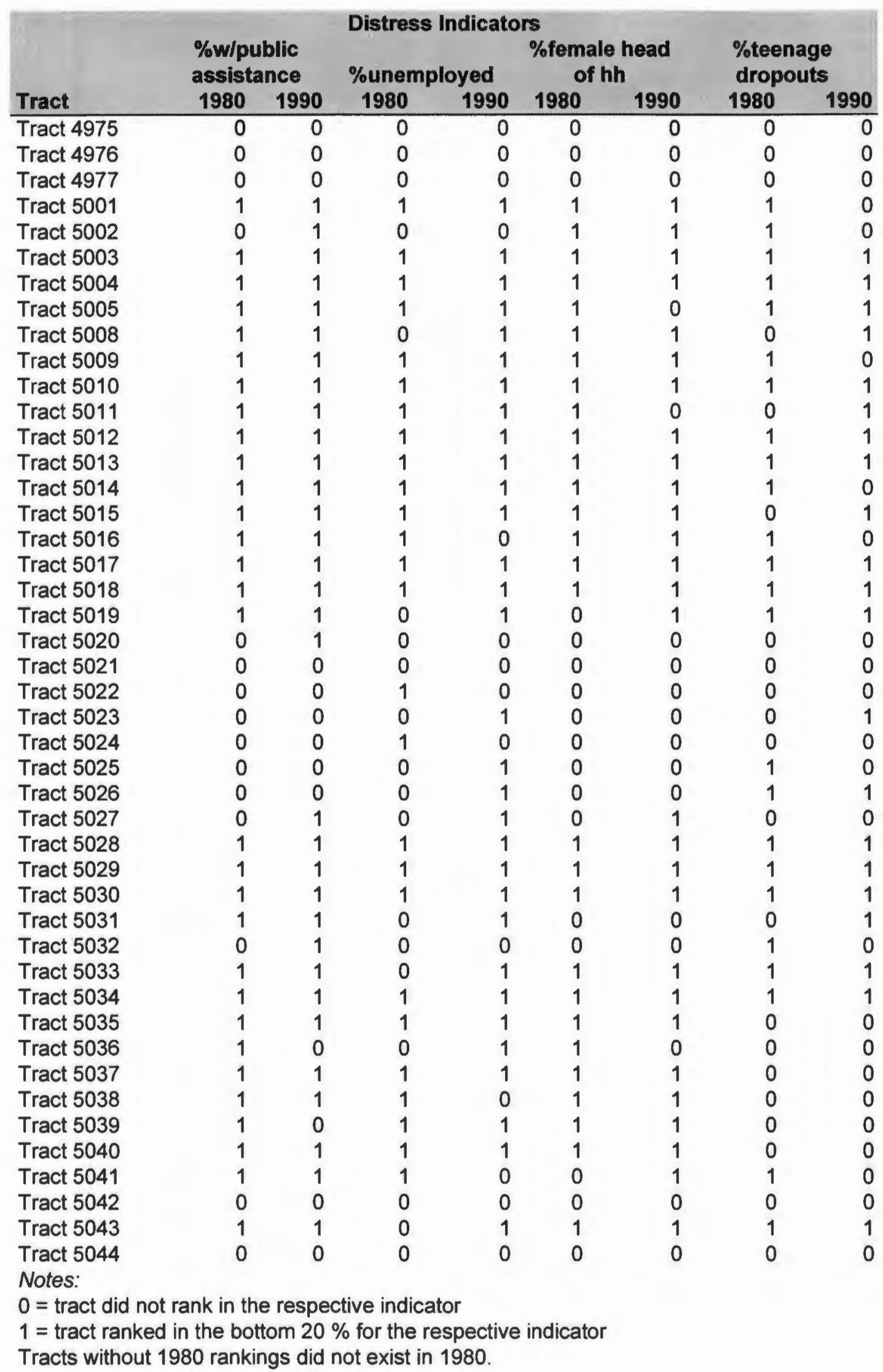




\begin{tabular}{|c|c|c|c|c|c|c|c|c|}
\hline \multirow[b]{3}{*}{ Tract } & \multicolumn{6}{|c|}{ Distress Indicators } & \multirow{2}{*}{\multicolumn{2}{|c|}{$\begin{array}{l}\text { \%teenage } \\
\text { dropouts }\end{array}$}} \\
\hline & \multicolumn{2}{|c|}{$\begin{array}{l}\text { \%w/public } \\
\text { assistance }\end{array}$} & \multicolumn{2}{|c|}{ \%unemployed } & \multicolumn{2}{|c|}{$\begin{array}{c}\text { \%female head } \\
\text { of hh }\end{array}$} & & \\
\hline & 1980 & 1990 & 1980 & 1990 & 1980 & 1990 & 1980 & 1990 \\
\hline Tract 5045 & 0 & 1 & 1 & 0 & 0 & 1 & 0 & 0 \\
\hline Tract 5046 & 1 & 1 & 1 & 1 & 1 & 1 & 1 & 1 \\
\hline Tract 5047 & 0 & 0 & 0 & 0 & 0 & 1 & 0 & 0 \\
\hline Tract 5048 & 0 & 0 & 0 & 0 & 0 & 0 & 0 & 0 \\
\hline Tract 5049 & 1 & 1 & 1 & 1 & 1 & 1 & 1 & 1 \\
\hline Tract 5101 & 0 & 0 & 0 & 0 & 0 & 0 & 0 & 0 \\
\hline Tract 5102 & 0 & 0 & 0 & 1 & 0 & 0 & 1 & 1 \\
\hline Tract 5103 & 1 & 1 & 0 & 1 & 1 & 1 & 1 & 1 \\
\hline Tract 5104 & 0 & 0 & 0 & 0 & 0 & 0 & 1 & 1 \\
\hline Tract 5105 & 0 & 0 & 0 & 0 & 0 & 0 & 0 & 0 \\
\hline Tract 5106 & 0 & 0 & 0 & 0 & 1 & 1 & 0 & 0 \\
\hline Tract 5107 & 0 & 0 & 0 & 0 & 0 & 0 & 0 & 0 \\
\hline Tract 5108 & 0 & 0 & 0 & 0 & 0 & 0 & 0 & 1 \\
\hline Tract 5109 & 0 & 0 & 0 & 0 & 0 & 0 & 0 & 0 \\
\hline Tract 5110 & 0 & 0 & 0 & 0 & 0 & 0 & 0 & 0 \\
\hline Tract 5111 & 0 & 0 & 0 & 0 & 0 & 0 & 0 & 0 \\
\hline Tract 5112 & 0 & 0 & 0 & 0 & 1 & 0 & 0 & 0 \\
\hline Tract 5113 & 0 & 0 & 0 & 1 & 0 & 0 & 1 & 0 \\
\hline Tract 5114 & 0 & 0 & 0 & 0 & 0 & 0 & 0 & 0 \\
\hline Tract 5141 & 0 & 0 & 0 & 0 & 0 & 0 & 0 & 0 \\
\hline Tract 5142 & 0 & 0 & 0 & 0 & 0 & 0 & 0 & 0 \\
\hline Tract 5143 & 0 & 0 & 0 & 0 & 0 & 0 & 0 & 0 \\
\hline Tract 5144 & 0 & 0 & 0 & 0 & 0 & 0 & 0 & 1 \\
\hline Tract 5145 & 0 & 0 & 0 & 0 & 0 & 0 & 0 & 0 \\
\hline Tract 5146 & 0 & 0 & 0 & 0 & 0 & 0 & 1 & 0 \\
\hline Tract 5147 & 0 & 1 & 0 & 0 & 0 & 0 & 0 & 1 \\
\hline Tract 5148 & 0 & 0 & 0 & 0 & 0 & 0 & 0 & 0 \\
\hline Tract 5149 & 0 & 0 & 0 & 0 & 0 & 0 & 0 & 0 \\
\hline Tract 5150 & 0 & 0 & 0 & 0 & 0 & 0 & 0 & 0 \\
\hline Tract 5151.01 & & 0 & & 0 & & 0 & & 0 \\
\hline Tract 5151.02 & 0 & 0 & 0 & 0 & 0 & 0 & 0 & 1 \\
\hline Tract 5152 & 0 & 0 & 0 & 0 & 0 & 0 & 0 & 0 \\
\hline Tract 5201 & 0 & 0 & 0 & 0 & 0 & 0 & 0 & 0 \\
\hline Tract 5202.01 & 0 & 0 & 0 & 0 & 0 & 0 & 0 & 0 \\
\hline Tract 5202.02 & 0 & 0 & 0 & 0 & 0 & 0 & 0 & 0 \\
\hline Tract 5203 & 0 & 0 & 0 & 0 & 0 & 0 & 0 & 0 \\
\hline Tract 5204 & 0 & 0 & 0 & 0 & 0 & 0 & 0 & 0 \\
\hline Tract 5205.01 & 0 & 0 & 0 & 0 & 0 & 0 & 0 & 0 \\
\hline Tract 5205.02 & 0 & 0 & 0 & 0 & 0 & 0 & 0 & 0 \\
\hline Tract 5241 & 0 & 0 & 0 & 0 & 0 & 0 & 0 & 0 \\
\hline Tract 5261 & 0 & 0 & 0 & 0 & 0 & 0 & 0 & 0 \\
\hline Tract 5281 & 0 & 0 & 0 & 0 & 0 & 0 & 0 & 0 \\
\hline Tract 5291 & 0 & 0 & 0 & 0 & 0 & 0 & 0 & 0 \\
\hline Tract 5301 & 0 & 0 & 0 & 0 & 0 & 0 & 1 & 0 \\
\hline Tract 5302 & 1 & 0 & 1 & 0 & 1 & 1 & 1 & 1 \\
\hline Notes: & & & & & & & & \\
\hline
\end{tabular}




\begin{tabular}{|c|c|c|c|c|c|c|c|c|}
\hline \multirow[b]{3}{*}{ Tract } & \multicolumn{6}{|c|}{ Distress Indicators } & \multirow{2}{*}{\multicolumn{2}{|c|}{$\begin{array}{l}\text { \%teenage } \\
\text { dropouts }\end{array}$}} \\
\hline & \multicolumn{2}{|c|}{$\begin{array}{l}\text { \%w/public } \\
\text { assistance }\end{array}$} & \multicolumn{2}{|c|}{ \%unemployed } & \multicolumn{2}{|c|}{$\begin{array}{c}\text { \%female head } \\
\text { of hh }\end{array}$} & & \\
\hline & 1980 & 1990 & 1980 & 1990 & 1980 & 1990 & 1980 & 1990 \\
\hline Tract 5303.01 & 0 & 0 & 0 & 0 & 0 & 0 & 0 & 0 \\
\hline Tract 5303.02 & 0 & 0 & 0 & 0 & 0 & 0 & 0 & 0 \\
\hline Tract 5304 & 0 & 0 & 0 & 0 & 0 & 0 & 0 & 0 \\
\hline Tract 5305 & 0 & 0 & 1 & 0 & 0 & 0 & 0 & 0 \\
\hline Tract 5306 & 0 & 0 & 0 & 0 & 0 & 0 & 0 & 0 \\
\hline Tract 5331.01 & 0 & 0 & 0 & 0 & 0 & 0 & 0 & 0 \\
\hline Tract 5331.02 & 0 & 0 & 0 & 0 & 0 & 0 & 0 & 0 \\
\hline Tract 5351 & 0 & 0 & 0 & 0 & 0 & 0 & 0 & 0 \\
\hline Tract 5352 & 0 & 0 & 0 & 0 & 0 & 0 & 0 & 0 \\
\hline Tract 5382.01 & & 0 & & 0 & & 0 & & 0 \\
\hline Tract 5382.02 & 0 & 0 & 0 & 0 & 0 & 0 & 0 & 0 \\
\hline
\end{tabular}

Capitol Region Rankings

\begin{tabular}{|c|c|c|c|c|c|c|c|c|}
\hline \multirow[b]{3}{*}{ Tract } & \multicolumn{6}{|c|}{ Rental Indicators } & \multirow{2}{*}{\multicolumn{2}{|c|}{ \%afford }} \\
\hline & \multicolumn{2}{|c|}{ \%hhwkids } & \multicolumn{2}{|c|}{ \%renter } & \multicolumn{2}{|c|}{ \%vacant rental } & & \\
\hline & 1980 & 1990 & 1980 & 1990 & 1980 & 1990 & 1980 & 1990 \\
\hline Tract 4601 & 0 & 0 & 0 & 0 & 0 & 1 & 0 & 0 \\
\hline Tract 4602.01 & & 0 & & 0 & & 1 & & 0 \\
\hline Tract 4602.02 & 0 & 0 & 0 & 0 & 0 & 0 & 0 & 0 \\
\hline Tract 4603 & 0 & 1 & 0 & 0 & 0 & 0 & 0 & 0 \\
\hline Tract 4621.01 & & 0 & & 0 & & 0 & & 0 \\
\hline Tract 4621.02 & 1 & 1 & 0 & 0 & 1 & 0 & 0 & 0 \\
\hline Tract 4622.01 & & 0 & & 0 & & 0 & & 0 \\
\hline Tract 4622.02 & 0 & 0 & 0 & 1 & 1 & 1 & 0 & 0 \\
\hline Tract 4641.01 & & 1 & & 0 & & 0 & & 0 \\
\hline Tract 4641.02 & 0 & 0 & 0 & 0 & 1 & 0 & 0 & 1 \\
\hline Tract 4661.01 & & 0 & & 0 & & 0 & & 0 \\
\hline Tract 4661.02 & 1 & 1 & 0 & 0 & 1 & 0 & 0 & 0 \\
\hline Tract 4662.01 & & 1 & & 0 & & 0 & & 0 \\
\hline Tract 4662.02 & 1 & 1 & 0 & 0 & 0 & 1 & 0 & 0 \\
\hline Tract 4663 & 1 & 1 & 0 & 0 & 0 & 1 & 0 & 0 \\
\hline Tract 4664 & 0 & 0 & 0 & 0 & 0 & 0 & 1 & 1 \\
\hline Tract 4681.01 & & 1 & & 0 & & 0 & & 0 \\
\hline Tract 4681.02 & 1 & 0 & 0 & 0 & 0 & 1 & 0 & 1 \\
\hline Tract 4701 & 1 & 0 & 0 & 0 & 0 & 0 & 0 & 1 \\
\hline Tract 4711 & 1 & 1 & 0 & 0 & 0 & 0 & 0 & 0 \\
\hline Tract 4712 & 0 & 0 & 0 & 0 & 1 & 0 & 0 & 0 \\
\hline Tract 4713 & 0 & 0 & 0 & 0 & 0 & 0 & 0 & 0 \\
\hline Tract 4714 & 0 & 0 & 0 & 0 & 0 & 0 & 1 & 1 \\
\hline Tract 4715 & 1 & 0 & 1 & 0 & 0 & 0 & 0 & 1 \\
\hline Tract $\mathbf{4 7 3 1}$ & 1 & 1 & 0 & 0 & 0 & 0 & 0 & 0 \\
\hline Tract 4734 & 0 & 0 & 0 & 1 & 1 & 0 & 0 & 1 \\
\hline Tract 4735.01 & 1 & 1 & 0 & 0 & 1 & 0 & 1 & 1 \\
\hline
\end{tabular}

Notes:

$0=$ tract did not rank in the respective indicator

$1=$ tract ranked in the bottom $20 \%$ for the respective indicator

Tracts without 1980 rankings did not exist in 1980. 


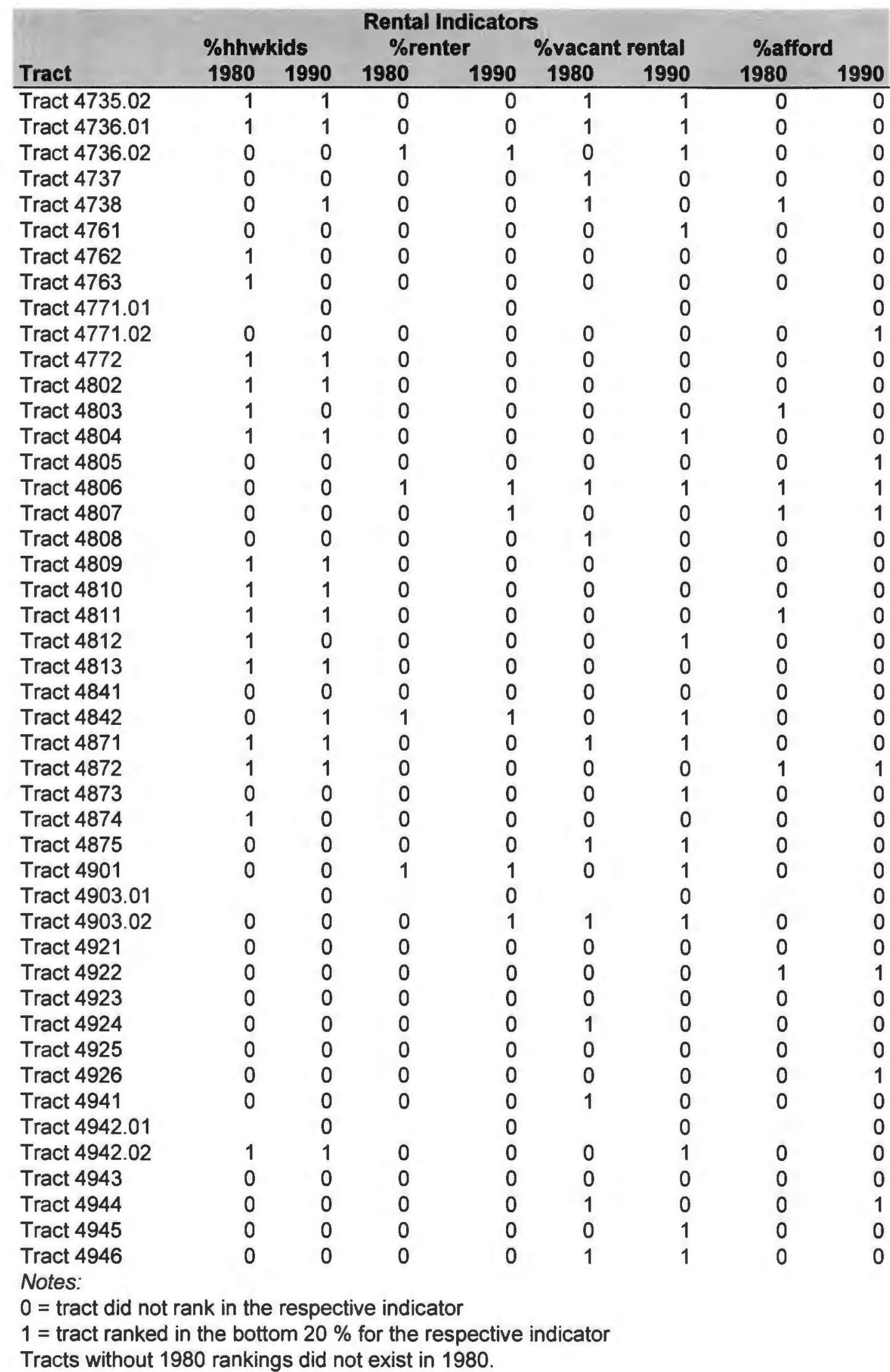




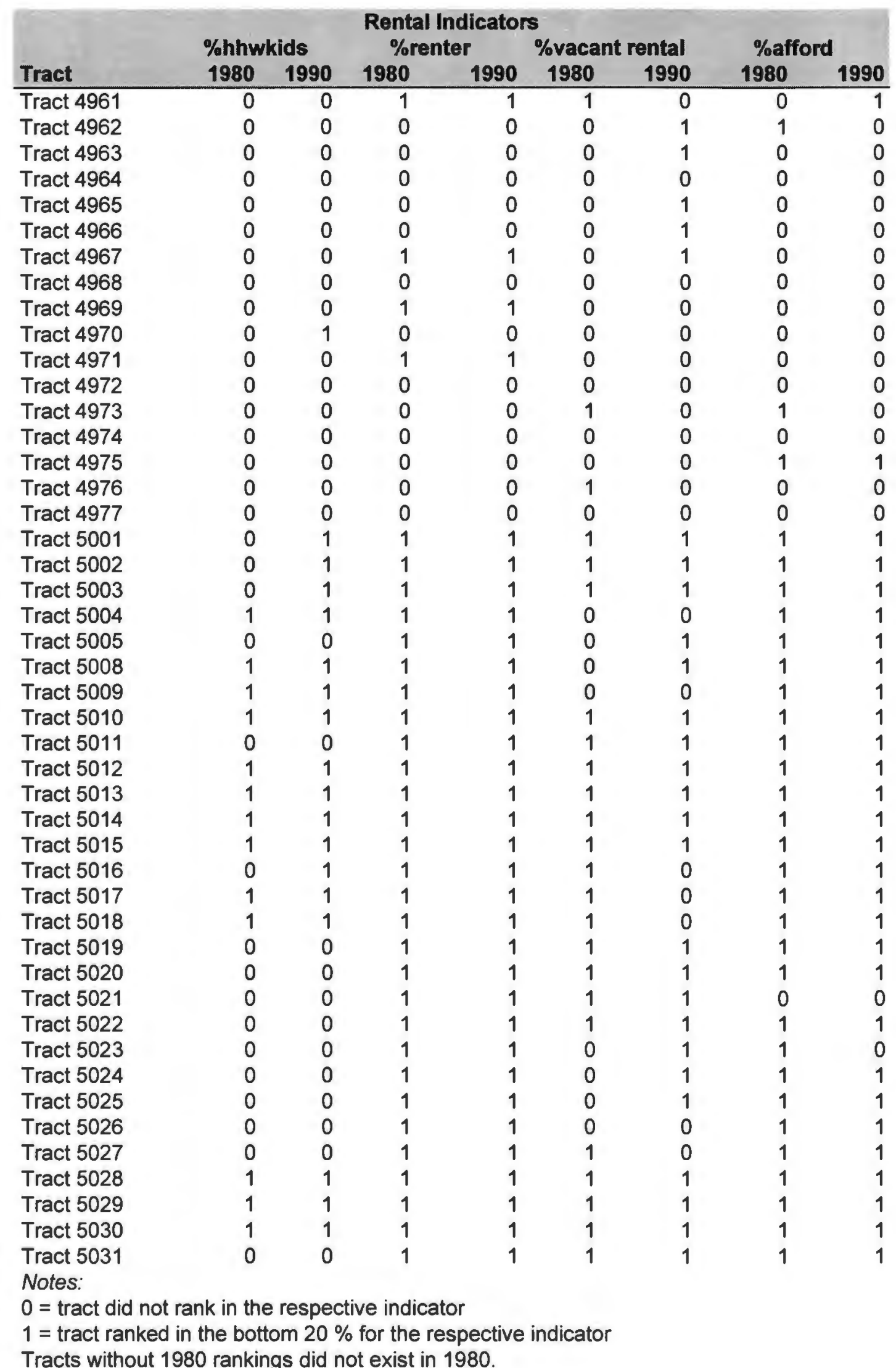




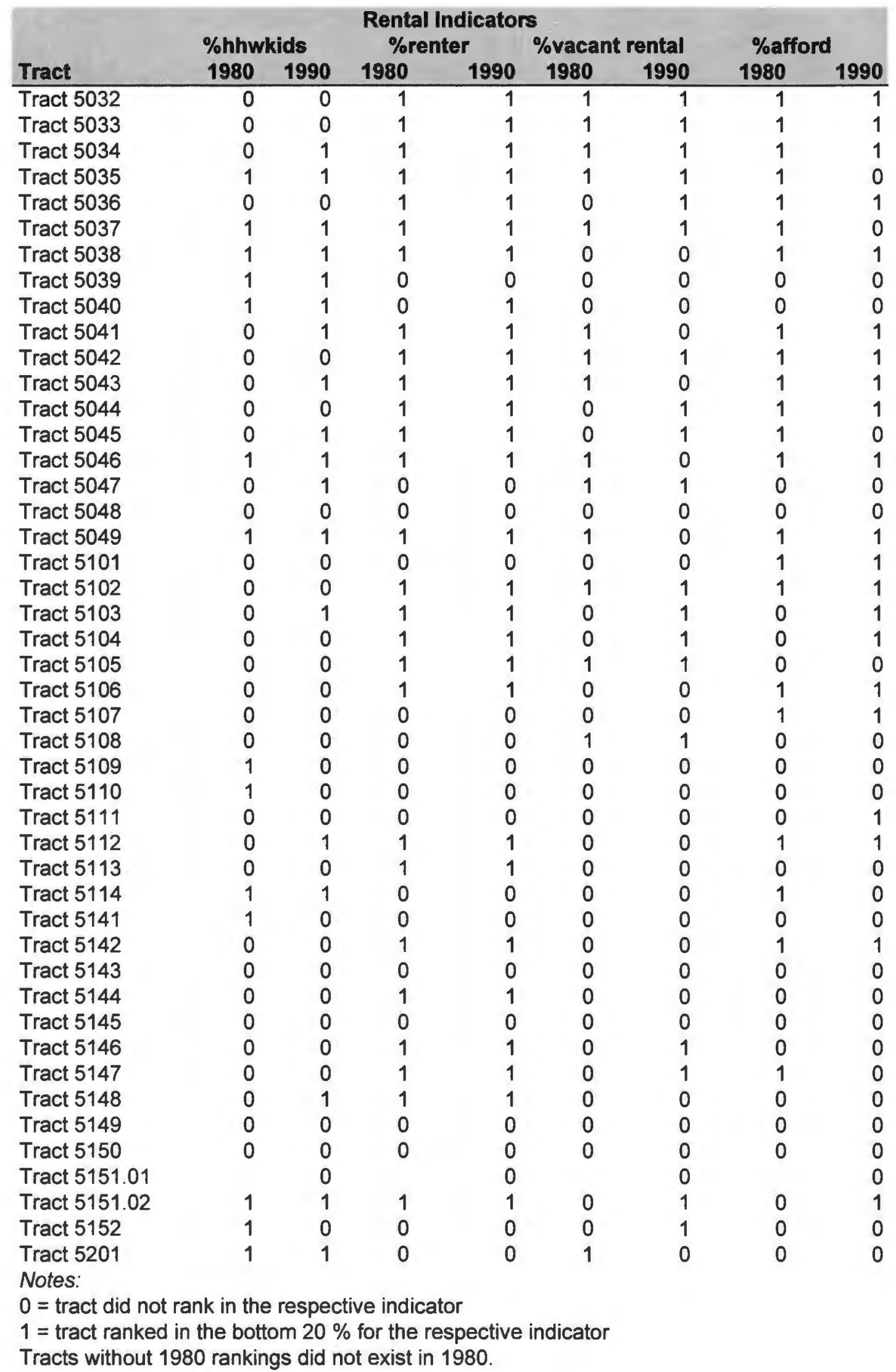




\begin{tabular}{|c|c|c|c|c|c|c|c|c|}
\hline \multirow[b]{3}{*}{ Tract } & \multicolumn{6}{|c|}{ Rental Indicators } & \multirow{2}{*}{\multicolumn{2}{|c|}{ \%afford }} \\
\hline & \multicolumn{2}{|c|}{ \%hhwkids } & \multicolumn{2}{|c|}{ \%renter } & \multicolumn{2}{|c|}{ \%vacant rental } & & \\
\hline & 1980 & 1990 & 1980 & 1990 & 1980 & 1990 & 1980 & 1990 \\
\hline Tract 5202.01 & 1 & 1 & 0 & 0 & 0 & 0 & 0 & 1 \\
\hline Tract 5202.02 & 1 & 1 & 0 & 0 & 0 & 1 & 0 & 0 \\
\hline Tract 5203 & 0 & 0 & 1 & 1 & 0 & 0 & 0 & 0 \\
\hline Tract 5204 & 1 & 0 & 0 & 0 & 0 & 0 & 0 & 0 \\
\hline Tract 5205.01 & 1 & 0 & 0 & 0 & 0 & 0 & 0 & 0 \\
\hline Tract 5205.02 & 1 & 1 & 0 & 0 & 0 & 1 & 0 & 0 \\
\hline Tract 5241 & 1 & 1 & 0 & 0 & 1 & 1 & 0 & 0 \\
\hline Tract 5261 & 1 & 1 & 0 & 0 & 1 & 0 & 0 & 0 \\
\hline Tract 5281 & 1 & 1 & 0 & 0 & 0 & 0 & 1 & 1 \\
\hline Tract 5291 & 0 & 1 & 0 & 0 & 0 & 0 & 0 & 0 \\
\hline Tract 5301 & 0 & 0 & 1 & 1 & 1 & 0 & 1 & 1 \\
\hline Tract 5302 & 0 & 0 & 1 & 1 & 1 & 1 & 1 & 1 \\
\hline Tract 5303.01 & 0 & 0 & 1 & 1 & 0 & 1 & 0 & 1 \\
\hline Tract 5303.02 & 1 & 0 & 0 & 0 & 1 & 0 & 0 & 0 \\
\hline Tract 5304 & 0 & 0 & 1 & 1 & 1 & 0 & 0 & 0 \\
\hline Tract 5305 & 1 & 1 & 0 & 0 & 0 & 0 & 1 & 1 \\
\hline Tract 5306 & 1 & 1 & 0 & 0 & 1 & 0 & 0 & 1 \\
\hline Tract 5331.01 & 1 & 1 & 0 & 0 & 1 & 0 & 1 & 1 \\
\hline Tract 5331.02 & 1 & 1 & 0 & 0 & 1 & 0 & 0 & 0 \\
\hline Tract 5351 & 1 & 0 & 0 & 1 & 0 & 1 & 1 & 0 \\
\hline Tract 5352 & 1 & 1 & 0 & 0 & 1 & 0 & 0 & 0 \\
\hline Tract 5382.01 & & 1 & & 0 & & 1 & & 0 \\
\hline Tract 5382.02 & 1 & 1 & 0 & 0 & 0 & 0 & 0 & 1 \\
\hline \multirow{2}{*}{\multicolumn{9}{|c|}{$\begin{array}{l}\text { Notes: } \\
0=\text { tract did not rank in the respective indicator }\end{array}$}} \\
\hline & & & & & & & & \\
\hline $1=$ tract ranke & the bot & om $20 \%$ & for the & pective & indica & & & \\
\hline Tracts without & nar- & odidid & & & & & & \\
\hline
\end{tabular}




\section{APPENDIX 3}

Percentage Change: $1980-1990$

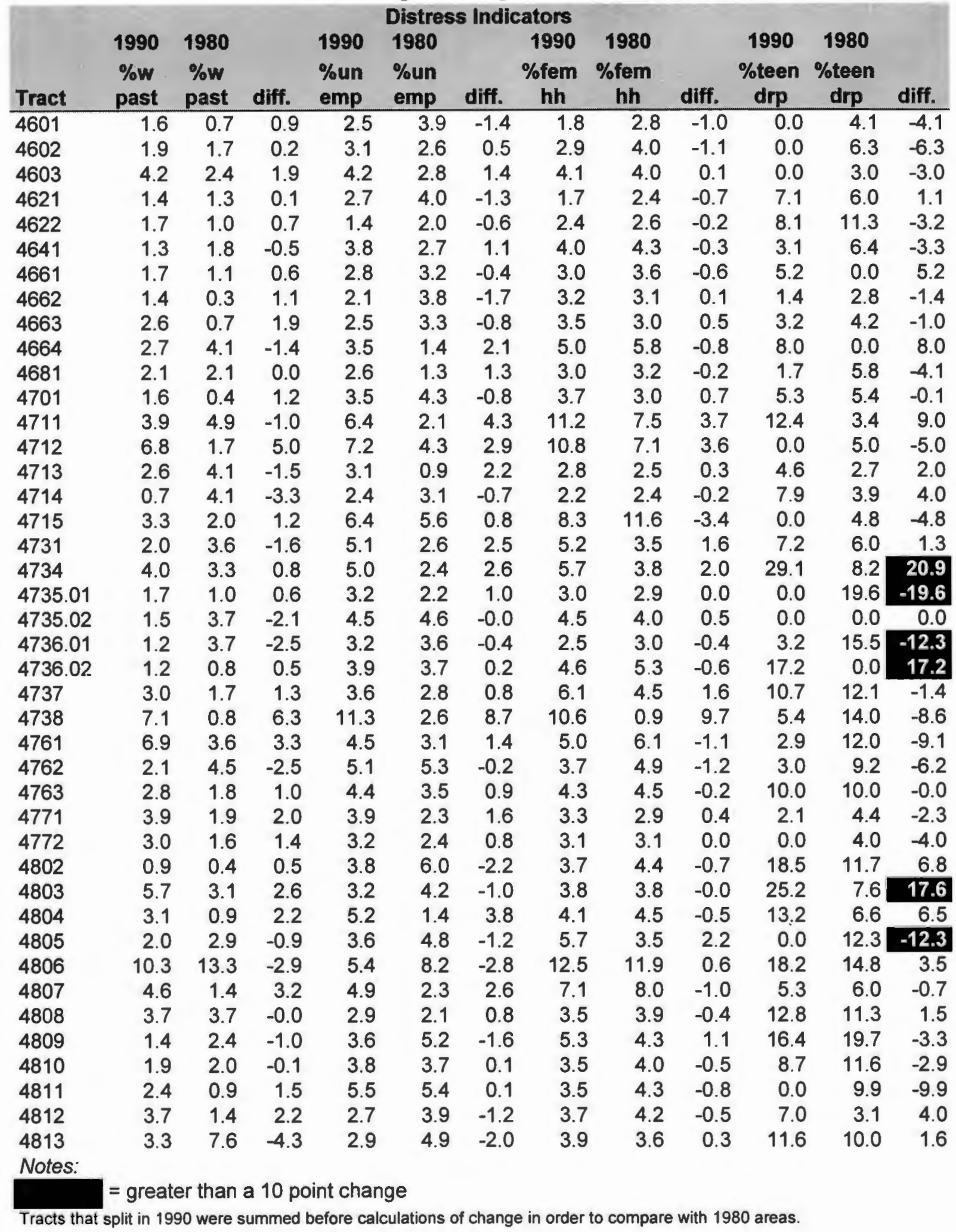




\begin{tabular}{|c|c|c|c|c|c|c|c|c|c|c|c|c|}
\hline & & & & & Distres & s Inc & ators & & & & & \\
\hline & 1990 & 1980 & & 1990 & 1980 & & 1990 & 1980 & & 1990 & 1980 & \\
\hline Tract & $\begin{array}{l}\% w \\
\text { past }\end{array}$ & $\begin{array}{l}\% w \\
\text { past }\end{array}$ & diff. & $\begin{array}{l}\text { \%un } \\
\text { emp }\end{array}$ & $\begin{array}{l}\% \text { un } \\
\text { emp }\end{array}$ & diff. & $\begin{array}{c}\% \text { fem } \\
\text { hh }\end{array}$ & $\begin{array}{c}\% \text { fem } \\
\text { hh }\end{array}$ & diff. & $\begin{array}{c}\text { \%teen } \\
\text { drp }\end{array}$ & $\begin{array}{c}\text { \%teen } \\
\text { drp }\end{array}$ & diff. \\
\hline 4841 & 3.1 & 5.0 & -1.9 & 3.6 & 3.6 & -0.0 & 3.4 & 4.6 & -1.2 & 6.2 & 10.6 & -4.4 \\
\hline 4842 & 2.9 & 6.0 & -3.1 & 3.6 & 2.2 & 1.4 & 5.2 & 5.3 & -0.1 & 13.2 & 9.9 & 3.3 \\
\hline 4871 & 1.7 & 0.6 & 1.0 & 2.2 & 3.1 & -0.9 & 3.4 & 3.3 & 0.2 & 0.0 & 1.1 & -1.1 \\
\hline 4872 & 3.7 & 0.7 & 3.0 & 2.0 & 4.7 & -2.7 & 2.6 & 3.8 & -1.2 & 7.6 & 2.7 & 4.9 \\
\hline 4873 & 3.7 & 2.4 & 1.3 & 4.5 & 6.0 & -1.5 & 2.3 & 2.7 & -0.4 & 0.0 & 9.8 & -9.8 \\
\hline 4874 & 1.8 & 2.3 & -0.5 & 3.1 & 7.4 & -4.3 & 5.5 & 3.0 & 2.5 & 6.1 & 0.0 & 6.1 \\
\hline 4875 & 1.3 & 3.3 & -2.0 & 2.1 & 2.7 & -0.6 & 4.1 & 5.2 & -1.1 & 9.9 & 2.9 & 7.0 \\
\hline 4901 & 2.0 & 4.8 & -2.8 & 4.7 & 3.4 & 1.3 & 3.8 & 4.6 & -0.8 & 3.5 & 17.0 & -13.4 \\
\hline 4903 & 1.2 & 1.9 & -0.7 & 1.2 & 2.9 & -1.7 & 2.6 & 3.3 & -0.7 & 3.0 & 4.2 & -1.2 \\
\hline 4921 & 2.3 & 0.9 & 1.4 & 2.6 & 3.9 & -1.3 & 4.1 & 3.1 & 1.0 & 7.0 & 2.8 & 4.2 \\
\hline 4922 & 5.4 & 3.6 & 1.8 & 4.1 & 4.4 & -0.3 & 6.3 & 3.9 & 2.4 & 34.1 & 3.2 & 30.9 \\
\hline 4923 & 2.4 & 3.7 & -1.3 & 3.6 & 4.6 & -1.0 & 4.4 & 3.0 & 1.4 & 10.1 & 10.0 & 0.1 \\
\hline 4924 & 1.5 & 0.9 & 0.5 & 1.0 & 3.8 & -2.8 & 2.3 & 2.2 & 0.1 & 6.5 & 1.6 & 4.9 \\
\hline 4925 & 1.9 & 0.6 & 1.3 & 5.2 & 2.3 & 2.9 & 3.0 & 2.7 & 0.3 & 0.0 & 2.2 & -2.2 \\
\hline 4926 & 3.0 & 2.9 & 0.1 & 3.6 & 3.9 & -0.3 & 1.7 & 2.3 & -0.7 & 3.6 & 0.0 & 3.6 \\
\hline 4941 & 4.7 & 1.6 & 3.1 & 3.9 & 2.8 & 1.1 & 5.6 & 4.9 & 0.7 & 0.0 & 2.1 & -2.1 \\
\hline 4942 & 3.0 & 3.5 & -0.5 & 3.0 & 2.0 & 1.0 & 5.2 & 6.0 & -0.8 & 2.9 & 6.2 & -3.3 \\
\hline 4943 & 1.3 & 1.8 & -0.5 & 4.3 & 3.0 & 1.3 & 3.9 & 4.9 & -1.0 & 0.0 & 7.9 & -7.9 \\
\hline 4944 & 3.9 & 3.2 & 0.6 & 2.5 & 1.9 & 0.6 & 3.1 & 2.7 & 0.4 & 7.8 & 1.7 & 6.1 \\
\hline 4945 & 1.7 & 1.9 & -0.2 & 3.4 & 3.1 & 0.3 & 3.9 & 3.7 & 0.3 & 6.8 & 16.0 & -9.2 \\
\hline 4946 & 1.6 & 3.1 & -1.5 & 3.5 & 1.4 & 2.1 & 2.6 & 3.0 & -0.3 & 16.5 & 5.1 & 11.4 \\
\hline 4961 & 9.4 & 9.1 & 0.3 & 6.2 & 4.5 & 1.7 & 10.0 & 8.3 & 1.7 & 12.4 & 5.3 & 7.2 \\
\hline 4962 & 4.9 & 3.5 & 1.4 & 3.6 & 3.3 & 0.3 & 3.0 & 2.7 & 0.2 & 5.0 & 7.7 & -2.7 \\
\hline 4963 & 2.3 & 3.8 & -1.5 & 3.1 & 0.7 & 2.4 & 4.7 & 4.3 & 0.5 & 14.5 & 2.9 & 11.6 \\
\hline 4964 & 2.0 & 3.2 & -1.3 & 3.8 & 1.5 & 2.3 & 3.1 & 3.2 & -0.2 & 0.0 & 2.1 & -2.1 \\
\hline 4965 & 3.6 & 1.3 & 2.3 & 2.7 & 3.2 & -0.5 & 2.9 & 3.0 & -0.0 & 6.9 & 4.7 & 2.2 \\
\hline 4966 & 0.0 & 0.5 & -0.5 & 2.8 & 1.6 & 1.2 & 1.9 & 3.3 & -1.4 & 0.0 & 0.0 & 0.0 \\
\hline 4967 & 3.6 & 2.8 & 0.8 & 2.4 & 4.7 & -2.3 & 4.3 & 3.4 & 0.9 & 0.0 & 14.1 & -14.1 \\
\hline 4968 & 6.0 & 2.4 & 3.6 & 4.1 & 1.6 & 2.5 & 4.9 & 3.3 & 1.5 & 10.5 & 11.4 & -0.9 \\
\hline 4969 & 6.3 & 3.5 & 2.8 & 3.6 & 3.3 & 0.3 & 5.0 & 4.0 & 1.0 & 14.0 & 5.2 & 8.7 \\
\hline 4970 & 2.4 & 2.3 & 0.1 & 2.6 & 2.9 & -0.3 & 3.6 & 3.0 & 0.6 & 2.8 & 7.9 & -5.0 \\
\hline 4971 & 5.1 & 1.6 & 3.4 & 6.9 & 1.0 & 5.9 & 4.3 & 3.0 & 1.3 & 16.4 & 8.4 & 8.0 \\
\hline 4972 & 2.2 & 0.0 & 2.2 & 3.7 & 2.5 & 1.2 & 2.0 & 2.0 & -0.0 & 0.0 & 2.9 & -2.9 \\
\hline 4973 & 3.3 & 0.6 & 2.7 & 7.9 & 1.3 & 6.6 & 2.7 & 2.8 & -0.0 & 0.8 & 5.3 & -4.5 \\
\hline 4974 & 0.7 & 1.8 & -1.1 & 1.7 & 1.0 & 0.7 & 2.3 & 2.6 & -0.3 & 0.0 & 0.0 & 0.0 \\
\hline 4975 & 4.3 & 1.9 & 2.4 & 2.3 & 4.1 & -1.8 & 2.6 & 2.0 & 0.6 & 0.0 & 4.4 & -4.4 \\
\hline 4976 & 2.5 & 3.9 & -1.4 & 4.8 & 2.2 & 2.6 & 5.1 & 3.5 & 1.6 & 0.0 & 0.0 & 0.0 \\
\hline 4977 & 1.2 & 0.3 & 0.9 & 4.2 & 1.7 & 2.5 & 1.7 & 1.9 & -0.2 & 0.0 & 0.0 & 0.0 \\
\hline 5001 & 24.5 & 15.1 & 9.4 & 13.3 & 7.3 & 6.0 & 19.7 & 11.1 & 8.6 & 9.1 & 20.4 & -11.4 \\
\hline 5002 & 29.0 & 8.1 & 20.9 & 7.5 & 5.4 & 2.1 & 28.3 & 13.4 & 14.9 & 16.3 & 26.3 & -10.1 \\
\hline 5003 & 33.8 & 29.7 & 4.1 & 12.2 & 12.1 & 0.0 & 27.3 & 18.6 & 8.7 & 38.9 & 30.7 & 8.2 \\
\hline 5004 & 39.8 & 35.4 & 4.4 & 20.4 & 9.7 & 10.7 & 39.7 & 27.6 & 12.1 & 38.2 & 22.6 & 15.6 \\
\hline 5005 & 25.2 & 22.2 & 2.9 & 8.4 & 10.3 & -1.9 & 9.2 & 9.7 & -0.5 & 32.4 & 26.2 & 6.2 \\
\hline 5008 & 45.5 & 35.1 & 10.4 & 18.6 & 2.9 & 15.7 & 34.3 & 28.7 & 5.5 & 39.0 & 0.0 & 39.0 \\
\hline 5009 & 53.5 & 64.3 & -10.8 & 25.8 & 31.7 & -5.9 & 57.3 & 45.2 & 12.2 & 16.2 & 56.0 & -39.9 \\
\hline 5010 & 54.7 & 44.6 & 10.1 & 25.6 & 14.8 & 10.8 & 56.9 & 45.2 & 11.7 & 35.9 & 32.3 & 3.6 \\
\hline Notes: & & & & & & & & & & & & \\
\hline & & & & & & & & & & & & \\
\hline
\end{tabular}




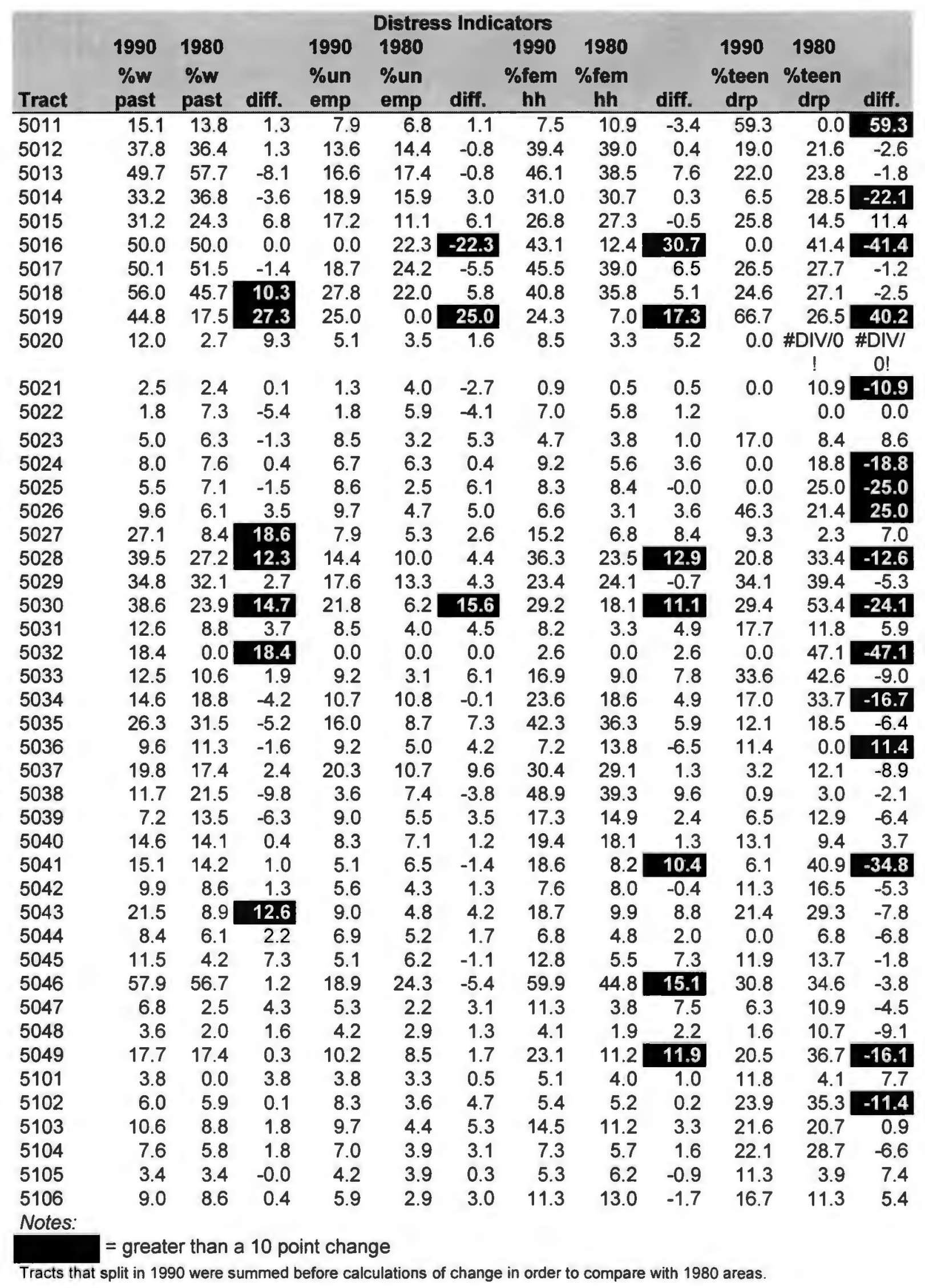




\begin{tabular}{|c|c|c|c|c|c|c|c|c|c|c|c|c|}
\hline \multirow[b]{3}{*}{ Tract } & \multirow{3}{*}{$\begin{array}{c}1990 \\
\% w \\
\text { past }\end{array}$} & \multirow{3}{*}{$\begin{array}{l}1980 \\
\% w \\
\text { past }\end{array}$} & \multirow[b]{3}{*}{ diff. } & \multirow{3}{*}{$\begin{array}{l}1990 \\
\% \text { un } \\
\text { emp } \\
\end{array}$} & \multicolumn{3}{|c|}{ Distress Indicators } & \multirow{3}{*}{$\begin{array}{c}1980 \\
\% \text { fem } \\
\text { hh }\end{array}$} & \multirow[b]{3}{*}{ diff. } & \multirow{3}{*}{$\begin{array}{l}1990 \\
\text { \%teen } \\
\text { drp }\end{array}$} & \multirow{3}{*}{$\begin{array}{c}1980 \\
\% \text { teen } \\
\text { drp }\end{array}$} & \multirow[b]{3}{*}{ diff. } \\
\hline & & & & & 1980 & & 1990 & & & & & \\
\hline & & & & & $\begin{array}{l}\text { \%un } \\
\text { emp }\end{array}$ & diff. & $\begin{array}{c}\text { \% fem } \\
\text { hh }\end{array}$ & & & & & \\
\hline 5107 & 6.9 & 5.1 & 1.8 & 2.7 & 3.4 & -0.7 & 6.9 & 6.0 & 0.9 & 8.1 & 12.4 & -4.3 \\
\hline 5108 & 5.0 & 5.1 & -0.0 & 7.1 & 4.0 & 3.1 & 6.1 & 6.0 & 0.1 & 17.0 & 11.6 & 5.4 \\
\hline 5109 & 0.5 & 4.2 & -3.7 & 1.8 & 3.1 & -1.3 & 3.7 & 4.3 & -0.6 & 0.0 & 4.2 & -4.2 \\
\hline 5110 & 3.9 & 4.0 & -0.2 & 3.6 & 2.1 & 1.5 & 2.9 & 3.8 & -0.9 & 7.0 & 10.9 & -3.9 \\
\hline 5111 & 2.8 & 1.4 & 1.4 & 2.9 & 2.4 & 0.5 & 2.8 & 2.7 & 0.2 & 10.3 & 7.3 & 2.9 \\
\hline 5112 & 7.7 & 6.3 & 1.4 & 5.1 & 4.4 & 0.7 & 10.0 & 9.8 & 0.2 & 11.6 & 10.1 & 1.5 \\
\hline 5113 & 3.9 & 3.9 & 0.0 & 9.0 & 3.2 & 5.8 & 6.1 & 3.1 & 3.1 & 11.2 & 19.0 & -7.9 \\
\hline 5114 & 1.6 & 2.9 & -1.3 & 3.6 & 3.0 & 0.6 & 3.3 & 2.9 & 0.4 & 0.0 & 0.0 & 0.0 \\
\hline 5141 & 1.1 & 2.3 & -1.1 & 4.5 & 3.5 & 1.0 & 8.0 & 7.7 & 0.3 & 3.4 & 5.3 & -1.9 \\
\hline 5142 & 5.2 & 5.3 & -0.1 & 5.2 & 3.8 & 1.4 & 9.5 & 4.5 & 5.0 & 6.3 & 15.1 & -8.9 \\
\hline 5143 & 2.2 & 5.1 & -2.9 & 2.8 & 1.7 & 1.1 & 4.8 & 0.6 & 4.2 & 2.9 & 2.7 & 0.2 \\
\hline 5144 & 4.0 & 6.0 & -1.9 & 3.0 & 4.0 & -1.0 & 8.1 & 6.7 & 1.4 & 26.6 & 12.8 & 13.8 \\
\hline 5145 & 3.7 & 4.7 & -1.0 & 4.5 & 4.1 & 0.4 & 4.2 & 3.8 & 0.4 & 15.9 & 11.1 & 4.8 \\
\hline 5146 & 7.5 & 5.5 & 2.0 & 2.8 & 4.1 & -1.3 & 6.8 & 6.7 & 0.1 & 7.6 & 21.4 & -13.8 \\
\hline 5147 & 10.4 & 6.3 & 4.2 & 7.6 & 3.9 & 3.7 & 8.1 & 6.7 & 1.5 & 23.3 & 11.7 & 11.5 \\
\hline 5148 & 7.9 & 6.1 & 1.8 & 3.5 & 2.7 & 0.8 & 9.5 & 7.0 & 2.4 & 4.9 & 5.3 & -0.3 \\
\hline 5149 & 1.3 & 0.8 & 0.4 & 2.6 & 2.6 & -0.0 & 2.9 & 3.8 & -0.9 & 14.8 & 7.0 & 7.7 \\
\hline 5150 & 3.1 & 0.6 & 2.5 & 3.0 & 1.1 & 1.9 & 2.4 & 2.5 & -0.0 & 5.2 & 3.5 & 1.6 \\
\hline 5151 & 2.8 & 3.9 & -1.1 & 2.8 & 3.1 & -0.3 & 7.2 & 7.6 & -0.4 & 14.1 & 4.5 & 9.6 \\
\hline 5152 & 1.2 & 2.1 & -0.9 & 0.6 & 2.5 & -1.9 & 3.3 & 4.7 & -1.4 & 5.4 & 0.0 & 5.4 \\
\hline 5201 & 1.2 & 2.1 & -0.8 & 2.2 & 3.7 & -1.5 & 2.9 & 3.0 & -0.1 & 0.0 & 6.7 & -6.7 \\
\hline 5202.01 & 1.8 & 1.8 & -0.0 & 2.8 & 3.0 & -0.2 & 2.3 & 1.6 & 0.7 & 0.0 & 0.0 & 0.0 \\
\hline 5202.02 & 0.7 & 2.5 & -1.8 & 2.8 & 0.6 & 2.2 & 2.0 & 0.8 & 1.2 & 0.0 & 0.0 & 0.0 \\
\hline 5203 & 2.4 & 5.3 & -2.9 & 2.9 & 2.5 & 0.4 & 7.4 & 7.9 & -0.5 & 8.3 & 5.9 & 2.3 \\
\hline 5204 & 2.2 & 2.7 & -0.5 & 3.5 & 1.7 & 1.8 & 2.5 & 3.1 & -0.6 & 4.7 & 1.1 & 3.6 \\
\hline 5205.01 & 3.5 & 1.0 & 2.4 & 3.1 & 3.4 & -0.3 & 2.3 & 3.8 & -1.4 & 0.0 & 0.0 & 0.0 \\
\hline 5205.02 & 0.0 & 8.8 & -8.8 & 0.0 & 3.8 & -3.8 & 2.9 & 2.1 & 0.9 & 0.0 & 6.7 & -6.7 \\
\hline 5241 & 0.6 & 1.5 & -0.9 & 4.1 & 3.0 & 1.1 & 3.6 & 3.2 & 0.4 & 6.7 & 1.5 & 5.2 \\
\hline 5261 & 1.9 & 2.3 & -0.4 & 3.5 & 4.6 & -1.1 & 4.1 & 4.9 & -0.8 & 4.1 & 2.7 & 1.5 \\
\hline 5281 & 1.3 & 2.3 & -1.1 & 3.3 & 4.1 & -0.8 & 3.5 & 2.5 & 1.0 & 8.7 & 6.7 & 2.0 \\
\hline 5291 & 3.0 & 2.6 & 0.3 & 1.8 & 3.4 & -1.6 & 3.2 & 3.5 & -0.3 & 5.4 & 3.2 & 2.2 \\
\hline 5301 & 4.2 & 3.7 & 0.5 & 4.9 & 5.1 & -0.2 & 5.7 & 4.5 & 1.2 & 12.7 & 19.5 & -6.8 \\
\hline 5302 & 8.5 & 9.5 & -1.0 & 4.8 & 5.9 & -1.1 & 12.2 & 10.2 & 2.1 & 26.6 & 24.9 & 1.7 \\
\hline 5303.01 & 2.5 & 2.9 & -0.4 & 3.3 & 2.2 & 1.1 & 4.6 & 5.9 & -1.4 & 16.0 & 6.0 & 10.0 \\
\hline 5303.02 & 2.8 & 2.3 & 0.4 & 3.5 & 3.6 & -0.1 & 4.6 & 3.7 & 0.9 & 10.3 & 3.4 & 6.9 \\
\hline 5304 & 4.0 & 1.1 & 2.8 & 2.8 & 3.2 & -0.4 & 7.1 & 5.2 & 1.8 & 8.0 & 7.1 & 0.9 \\
\hline 5305 & 1.8 & 2.6 & -0.7 & 2.5 & 5.8 & -3.3 & 4.3 & 2.9 & 1.4 & 6.6 & 9.6 & -2.9 \\
\hline 5306 & 0.6 & 1.6 & -1.1 & 2.0 & 3.6 & -1.6 & 2.7 & 3.5 & -0.8 & 8.0 & 0.0 & 8.0 \\
\hline 5331.01 & 1.1 & 2.8 & -1.8 & 1.6 & 3.8 & -2.2 & 3.5 & 4.0 & -0.4 & 7.9 & 1.4 & 6.5 \\
\hline 5331.02 & 0.9 & 2.2 & -1.3 & 1.8 & 2.8 & -1.0 & 3.9 & 3.9 & 0.0 & 5.6 & 4.6 & 1.0 \\
\hline 5351 & 1.2 & 0.7 & 0.5 & 2.7 & 3.7 & -1.0 & 2.0 & 2.4 & -0.3 & 4.9 & 6.2 & -1.3 \\
\hline 5352 & 2.4 & 1.9 & 0.5 & 6.1 & 4.3 & 1.8 & 3.6 & 3.6 & 0.0 & 0.0 & 14.6 & -14.6 \\
\hline 5382 & 1.9 & 2.7 & -0.8 & 1.9 & 3.2 & -1.3 & 3.5 & 5.6 & -2.1 & 4.0 & 2.0 & 2.0 \\
\hline
\end{tabular}

Tracts that split in 1990 were summed before calculations of change in order to compare with 1980 areas. 
Percentage Change: $1980-1990$

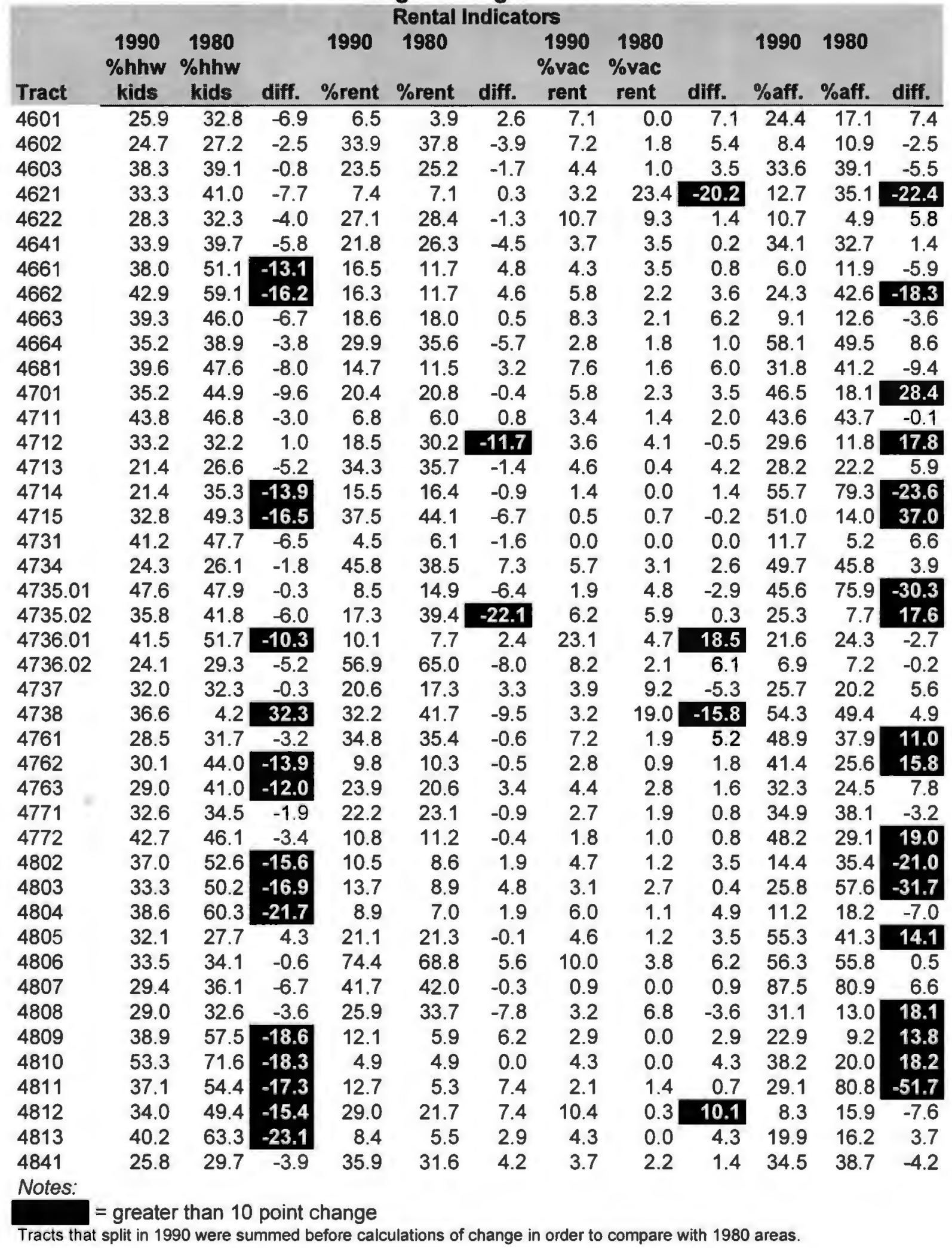




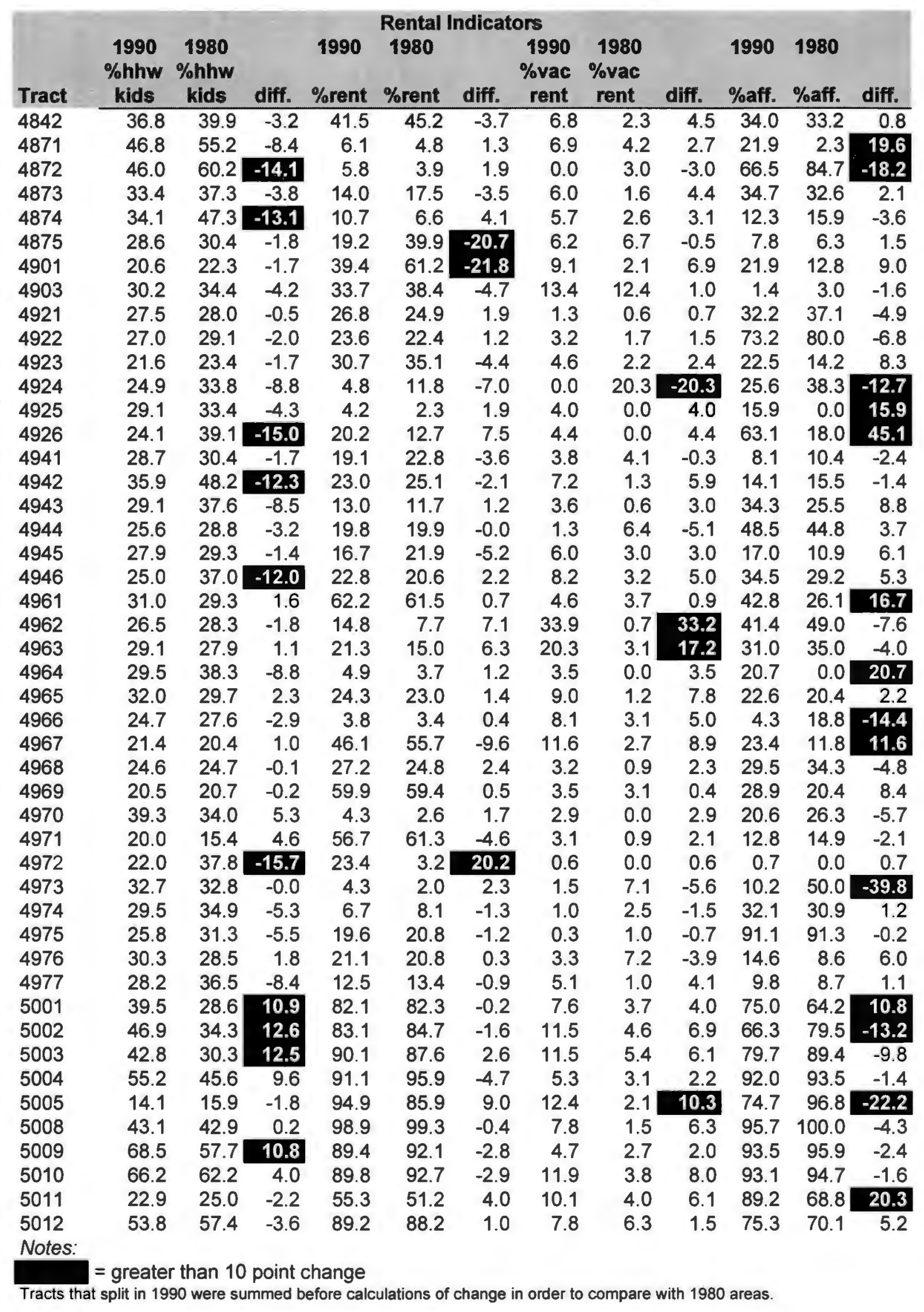




\begin{tabular}{|c|c|c|c|c|c|c|c|c|c|c|c|c|}
\hline & & & & & e & He & & & & & & \\
\hline Tract & $\begin{array}{c}1990 \\
\% h h w \\
\text { kids }\end{array}$ & $\begin{array}{c}1980 \\
\% \text { hhw } \\
\text { kids }\end{array}$ & diff. & $\%$ rent & $\begin{array}{l}1980 \\
\text { \%rent }\end{array}$ & diff. & $\begin{array}{r}1990 \\
\text { \%vac } \\
\text { rent }\end{array}$ & $\begin{array}{r}1980 \\
\text { \%vac } \\
\text { rent }\end{array}$ & diff. & \%aff. & $\%$ aff. & diff. \\
\hline 5013 & 59.7 & 52.5 & 7.2 & 80.0 & 90.3 & -10.2 & 8.5 & 4.2 & 4.3 & 88.0 & 87.6 & 0.4 \\
\hline 5014 & 45.9 & 47.4 & -1.5 & 85.6 & 84.3 & 1.3 & 8.4 & 5.2 & 3.3 & 83.5 & 74.6 & 8.9 \\
\hline 5015 & 39.9 & 47.1 & -7.2 & 76.5 & 73.9 & 2.6 & 7.9 & 3.6 & 4.3 & 78.6 & 61.9 & 16.7 \\
\hline 5016 & 51.4 & 20.2 & 31.1 & 97.3 & 89.7 & 7.6 & 4.1 & 5.9 & -1.8 & 94.9 & 91.5 & 3.4 \\
\hline 5017 & 64.3 & 59.2 & 5.1 & 91.7 & 84.2 & 7.5 & 5.3 & 9.3 & -4.1 & 87.7 & 90.5 & -2.8 \\
\hline 5018 & 57.9 & 53.3 & 4.6 & 86.8 & 84.4 & 2.5 & 4.3 & 6.6 & -2.3 & 83.5 & 89.9 & -6.4 \\
\hline 5019 & 31.6 & 16.3 & 15.3 & 94.3 & & 4.6 & 12.0 & 11.4 & 0.6 & 88.0 & 85.6 & 2.4 \\
\hline 5020 & 14.2 & 8.0 & 6.3 & 79.3 & 82.9 & -3.6 & 12.8 & 25.4 & -12.6 & 67.3 & 80.3 & -13.0 \\
\hline 5021 & 1.9 & 2.9 & -1.0 & 60.0 & 92.2 & -32.3 & 11.1 & 5.7 & 5.4 & 9.3 & 30.7 & -21.4 \\
\hline 5022 & 14.3 & 12.0 & 2.3 & 94.4 & 92.8 & 1.6 & 8.7 & 27.3 & -18.6 & 58.1 & 72.0 & -13.9 \\
\hline 5023 & 23.7 & 25.7 & -1.9 & 46.9 & 42.6 & 4.3 & 7.0 & 2.5 & 4.4 & 61.1 & 58.8 & 2.2 \\
\hline 5024 & 27.3 & 25.6 & 1.7 & 73.0 & 71.7 & 1.3 & 6.1 & 2.2 & 3.9 & 70.4 & 64.5 & 5.9 \\
\hline 5025 & 24.7 & 26.5 & -1.8 & 66.5 & 71.6 & -5.1 & 7.5 & 2.7 & 4.8 & 70.6 & 65.2 & 5.4 \\
\hline 5026 & 20.8 & 21.5 & -0.7 & 65.5 & & 6.5 & 4.7 & & & & 57.1 & 11.2 \\
\hline 502 & 30.7 & 16.7 & 14.0 & 87.0 & 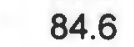 & 2.3 & 4.3 & 3. & 0.5 & .0 & 70.9 & 7.1 \\
\hline 5028 & 54.6 & 41.7 & 12.9 & 88.9 & & 6.4 & 7.9 & 5. & 2.5 & & & 8.6 \\
\hline 5029 & 40.3 & 43.2 & -2.9 & 93.0 & & 5.2 & 17.9 & 4.4 & 13.5 & & 83.3 & -15.3 \\
\hline 5030 & 46.6 & 41.1 & 5.5 & 88.6 & & 5.5 & 8.3 & 4.7 & 3.6 & 66.6 & 81.0 & -14.4 \\
\hline 5031 & 14.1 & 6.3 & 7.8 & 87.5 & 9 & -8.9 & 10.5 & 6.2 & 4.2 & 73.2 & 66.5 & 6.7 \\
\hline 5032 & 38 & 1.9 & 2.0 & 98.1 & 9 & -0.3 & 24.5 & 12.6 & 11.9 & 87.8 & 94.2 & -6.3 \\
\hline 5033 & 27.2 & 14.7 & 12.5 & 89.5 & 85.3 & 4.2 & 10.7 & 11.2 & -0.5 & 82.6 & 80.9 & 1.7 \\
\hline 5034 & 37.0 & 30.8 & 6.2 & 84.5 & $7 \varepsilon$ & 5.6 & 8.0 & 10.9 & -2.9 & & 75.1 & 2.7 \\
\hline 503 & 6 & 55.7 & 5.4 & 82.6 & 7 & 4 & 9 & & 2.9 & 6 & 54.8 & 11.8 \\
\hline 503 & & 32.1 & -5.7 & 70.1 & & -3 & & & 7.2 & & 76.7 & 20.3 \\
\hline 50 & & 10 & 1.6 & 70.9 & 72 & -1 & & 4. & 4.1 & & 6 & 14.0 \\
\hline 503 & & 2 & 3.2 & 9 & & & 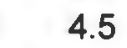 & & 3.5 & & 95.7 & 0.9 \\
\hline 5039 & 4 & .4 & -5.6 & 23.9 & ? & 0.6 & 4.1 & 2.8 & 1.3 & 48.3 & 22.1 & 26.2 \\
\hline 5040 & 4 & .7 & -2.4 & 42.4 & & 1.4 & 2.1 & 1 & 0.8 & 52.8 & 25.2 & 27.6 \\
\hline 5041 & 40.7 & 33.2 & 7.5 & 78.1 & 71.4 & 6.7 & 4.2 & 4. & -0.8 & & 73.7 & 1.4 \\
\hline 504 & 16 & 18.6 & -2.5 & 89.4 & & & 9.7 & & 1.4 & & 60.9 & -5.7 \\
\hline 504 & 40. & & 8.6 & & & & 3 & 3.6 & -0.3 & 8 & 74.3 & -1.5 \\
\hline 504 & & 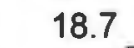 & 2.6 & & & & & & & 8 & 9 & -1.0 \\
\hline 50 & & & 12.5 & & & & & & & & .7 & 4.8 \\
\hline 50 & 7 & 686 & 4.7 & 95 & 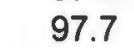 & -2.3 & 1 & 3. & -1.6 & 5 & 99.4 & -1.9 \\
\hline 504 & & 27.3 & 10.4 & 26.5 & 3 & -6.4 & 6.3 & 4. & 2.2 & 3 & 41.3 & -0.0 \\
\hline 504 & 2 & 25.4 & -2.7 & 32.2 & 16.6 & 15.6 & 4.9 & 2.6 & 2.3 & 52.1 & 40.6 & 11.4 \\
\hline 5049 & 4 & 40.5 & 9.0 & 68.5 & 65.4 & 3.1 & 4.8 & 3.8 & 1.0 & 77.5 & 75.8 & 1.7 \\
\hline 5101 & 27 & 33.5 & -6.4 & 39.2 & & 5.5 & 5.1 & 1.5 & 3.6 & 66.6 & 53.1 & 13.4 \\
\hline 510 & $?$ & 21 & -0.3 & 65.5 & 6 & 1.1 & 13.5 & 3.9 & 9.6 & 70.1 & $62.5^{\circ}$ & 7.6 \\
\hline 510 & & & 0.5 & 57.4 & & -0.7 & & 0 & & & 42.2 & 3.2 \\
\hline 5104 & 25.5 & 21.0 & 4.6 & 72.7 & 77.7 & -5.1 & 6.2 & 1.7 & 4.4 & & 40.5 & 15.0 \\
\hline 5105 & 22.6 & 28.4 & -5.8 & 58.0 & 68.1 & -10.1 & 9.0 & 5.5 & 3.5 & 20.4 & 14.6 & 5.7 \\
\hline 5106 & 27.5 & 29.9 & -2.4 & 64.3 & 67.2 & -3.0 & 2.3 & 1.2 & 1.1 & 74.4 & 55.1 & 19.3 \\
\hline 5107 & 30.8 & 34.1 & -3.3 & 28.1 & 27.7 & 0.5 & 2.9 & 0.5 & 2.4 & 63.1 & 56.3 & 6.8 \\
\hline 510 & 24.4 & 29.7 & -5.2 & 34.3 & 35.4 & -1.1 & 10.3 & 3.7 & 6.5 & 35.8 & 35.7 & 0.1 \\
\hline 510 & 32.5 & 51.7 & -19.2 & 3.6 & 2.9 & 0. & 1.9 & 0.0 & 1.9 & 29.5 & 3.7 & 25.8 \\
\hline 5110 & 30.8 & 40.8 & -10.0 & 3.4 & 3.4 & 0.0 & 2.1 & 0.0 & 2.1 & 40.9 & 0.0 & 40.9 \\
\hline
\end{tabular}
Notes:

= greater than 10 point change

Tracts that split in 1990 were summed before calculations of change in order to compare with 1980 areas. 


\begin{tabular}{|c|c|c|c|c|c|c|c|c|c|c|c|c|}
\hline \multirow[b]{2}{*}{ Tract } & \multirow[b]{2}{*}{$\begin{array}{c}1990 \\
\text { \%hhw } \\
\text { kids }\end{array}$} & \multirow[b]{2}{*}{$\begin{array}{c}1980 \\
\% \text { hhw } \\
\text { kids }\end{array}$} & \multirow[b]{2}{*}{ diff. } & \multirow[b]{2}{*}{$\begin{array}{l}1990 \\
\text { \%rent } \\
\end{array}$} & \multicolumn{3}{|c|}{ Rental Indicators } & \multirow[b]{2}{*}{$\begin{array}{c}1980 \\
\% \text { vac } \\
\text { rent }\end{array}$} & \multirow[b]{2}{*}{ diff. } & \multirow[b]{2}{*}{$\begin{array}{l}1990 \\
\text { \%aff. }\end{array}$} & \multirow[b]{2}{*}{$\begin{array}{l}1980 \\
\% \text { aff. }\end{array}$} & \multirow[b]{2}{*}{ diff. } \\
\hline & & & & & $\begin{array}{l}1980 \\
\% r e n t\end{array}$ & diff. & $\begin{array}{r}1990 \\
\% \text { vac } \\
\text { rent }\end{array}$ & & & & & \\
\hline 5111 & 22.9 & 33.7 & -10.8 & 5.1 & 3.5 & 1.6 & 4.2 & 0.0 & 4.2 & 34.0 & 41.7 & -7.7 \\
\hline 5112 & 35.6 & 39.1 & -3.6 & 44.0 & 44.2 & -0.2 & 2.3 & 1.9 & 0.5 & 68.7 & 68.4 & 0.3 \\
\hline 5113 & 26.2 & 19.6 & 6.6 & 52.9 & 61.6 & -8.6 & 5.2 & 2.0 & 3.2 & 36.2 & 29.4 & 6.9 \\
\hline 5114 & 36.2 & 52.8 & -16.6 & 4.4 & 4.8 & -0.3 & 5.3 & 0.0 & 5.3 & 55.2 & 61.9 & -6.7 \\
\hline 5141 & 34.8 & 46.5 & -11.7 & 34.7 & 34.9 & -0.2 & 5.1 & 0.5 & 4.6 & 29.4 & 19.2 & 10.2 \\
\hline 5142 & 29.2 & $26.4^{\circ}$ & 2.8 & 45.1 & 47.1 & -2.0 & 3.2 & 2.7 & 0.4 & 61.4 & 49.0 & 12.4 \\
\hline 5143 & 32.8 & 34.4 & -1.6 & 24.3 & 23.9 & 0.3 & 1.4 & 1.0 & 0.4 & 28.9 & 15.3 & 13.6 \\
\hline 5144 & 29.6 & 30.2 & -0.6 & 52.0 & 54.6 & -2.5 & 3.3 & 1.7 & 1.6 & 36.8 & 28.2 & 8.6 \\
\hline 5145 & 30.0 & 30.6 & -0.6 & 28.4 & 28.7 & -0.3 & 1.9 & 1.1 & 0.8 & 19.7 & 11.3 & 8.4 \\
\hline 5146 & 26.6 & 28.2 & -1.5 & 58.8 & 52.2 & 6.6 & 8.2 & 1.8 & 6.4 & 39.1 & 38.0 & 1.1 \\
\hline 5147 & 22.6 & 24.5 & -1.9 & 80.0 & 78.3 & 1.6 & 6.0 & 2.3 & 3.7 & 42.9 & 50.1 & -7.2 \\
\hline 5148 & 35.3 & 34.4 & 0.9 & 49.9 & 46.1 & 3.7 & 4.5 & 1.1 & 3.4 & 43.5 & 31.0 & 12.5 \\
\hline 5149 & 29.2 & 37.1 & -7.8 & 6.0 & 7.2 & -1.1 & 4.1 & 0.0 & 4.1 & 30.2 & 10.3 & 19.9 \\
\hline 5150 & 25.9 & 32.7 & -6.8 & 9.5 & 9.5 & 0.0 & 1.9 & 1.0 & 0.8 & 45.1 & 11.1 & 34.0 \\
\hline 5151 & 38.4 & 43.2 & -4.8 & 43.4 & 50.7 & -7.3 & 12.1 & 2.7 & 9.4 & 40.6 & 30.1 & 10.5 \\
\hline 5152 & 35.1 & 40.6 & -5.4 & 23.3 & 30.5 & -7.1 & 8.2 & 1.2 & 7.0 & 14.0 & 6.5 & 7.6 \\
\hline 5201 & 46.3 & 53.2 & -6.9 & 10.8 & 16.9 & -6.1 & 5.2 & 9.8 & -4.6 & 8.4 & 11.1 & -2.6 \\
\hline 5202.01 & 43.0 & 53.1 & -10.1 & 5.0 & 3.5 & 1.5 & 0.0 & 0.0 & 0.0 & 32.8 & 0.0 & 0.0 \\
\hline 5202.02 & 48.7 & 53.5 & -4.7 & 8.9 & 11.8 & -2.9 & 7.6 & 0.0 & 7.6 & 50.0 & 36.4 & 13.6 \\
\hline 5203 & 25.9 & 30.9 & -5.0 & 46.7 & 54.4 & -7.7 & 5.3 & 3.0 & 2.2 & 34.7 & $34.2^{\circ}$ & 0.6 \\
\hline 5204 & 30.2 & 42.7 & -12.5 & 11.4 & 7.0 & 4.3 & 4.7 & 1.3 & 3.4 & 40.0 & 45.8 & -5.8 \\
\hline 5205.01 & 35.0 & 42.7 & -7.7 & 10.0 & 12.8 & -2.8 & 3.5 & 0.0 & 3.5 & 33.3 & 34.5 & -1.2 \\
\hline 5205.02 & 40.8 & 41.8 & -0.9 & 11.9 & 12.2 & -0.4 & 10.8 & 0.0 & 10.8 & 22.0 & 0.0 & 22.0 \\
\hline 5241 & 48.7 & 52.1 & -3.4 & 10.7 & 10.5 & 0.2 & 6.5 & 3.1 & 3.4 & 33.4 & 42.3 & -8.9 \\
\hline 5261 & 50.8 & 55.6 & -4.8 & 11.2 & 13.1 & -1.9 & 4.7 & 5.1 & -0.4 & 17.6 & 33.0 & -15.4 \\
\hline 5281 & 37.5 & 43.0 & -5.5 & 14.0 & 13.4 & 0.6 & 1.5 & 2.9 & -1.4 & 75.6 & 57.1 & 18.5 \\
\hline 5291 & 37.2 & 40.4 & -3.2 & 15.1 & 14.6 & 0.5 & 1.6 & 1.5 & 0.0 & 36.1 & 29.9 & 6.2 \\
\hline 5301 & 27.6 & 26.4 & 1.2 & 44.3 & 42.7 & 1.6 & 4.8 & 4.0 & 0.9 & 73.5 & 71.3 & 2.2 \\
\hline 5302 & 34.8 & 36.0 & -1.2 & 67.3 & 65.0 & 2.3 & 7.8 & 3.3 & 4.5 & 57.5 & 56.3 & 1.2 \\
\hline 5303.01 & 25.9 & 33.6 & -7.7 & 45.5 & 59.6 & -14.1 & 6.1 & 2.0 & 4.1 & 43.2 & 41.9 & 1.2 \\
\hline 5303.02 & 32.6 & 50.8 & -18.2 & 23.6 & 15.4 & 8.1 & 3.2 & 4.7 & -1.5 & 37.5 & 25.9 & 11.6 \\
\hline 5304 & 27.9 & 35.2 & -7.3 & 60.4 & 58.8 & 1.6 & 4.4 & 5.0 & -0.6 & 39.5 & 40.7 & -1.3 \\
\hline 5305 & 42.0 & 46.6 & -4.6 & 14.1 & 18.4 & -4.3 & 4.5 & 0.6 & 3.9 & 76.0 & 65.1 & 10.9 \\
\hline 5306 & 42.0 & 55.8 & -13.8 & 3.5 & 4.5 & -1.0 & 0.0 & 8.1 & -8.1 & 38.5 & 0.0 & 38.5 \\
\hline 5331.01 & 44.3 & 55.8 & -11.5 & 8.0 & 8.3 & -0.2 & 2.4 & 5.7 & -3.3 & 48.2 & 70.1 & -21.9 \\
\hline 5331.02 & 49.5 & 58.6 & -9.1 & 9.5 & 11.4 & -1.9 & 3.2 & 8.9 & -5.7 & 16.5 & 5.4 & 11.2 \\
\hline 5351 & 33.4 & 44.1 & -10.7 & 40.8 & 37.8 & 2.9 & 8.2 & 1.9 & 6.3 & 31.0 & 46.3 & -15.3 \\
\hline 5352 & 35.8 & 42.6 & -6.8 & 12.0 & 9.7 & 2.3 & 4.4 & 7.3 & -2.9 & 51.2 & 42.7 & 8.5 \\
\hline 5382 & 38.4 & 47.1 & -8.7 & 14.9 & 16.6 & -1.7 & 5.9 & 1.5 & 4.4 & 35.9 & 37.0 & -1.1 \\
\hline
\end{tabular}




\section{APPENDIX 4}

Capitol Region Rental Units and Tenant-Assisted Units By Town and Tract, 1996

\begin{tabular}{|c|c|c|c|c|}
\hline Andover (1.5) ${ }^{\mathrm{a}}$ & 5281 & 137 & 2 & 1.5 \\
\hline \multirow[t]{4}{*}{$\overline{\text { Avon (0.2) }}$} & 4621.01 & 157 & 1 & 0.6 \\
\hline & 4621.02 & 62 & 0 & 0.0 \\
\hline & 4622.01 & 310 & 1 & 0.3 \\
\hline & 4622.02 & 430 & 0 & 0.0 \\
\hline \multirow[t]{5}{*}{ Bloomfield (4.4) } & 4711 & 88 & 18 & 20.5 \\
\hline & 4712 & 224 & 29 & 12.9 \\
\hline & 4713 & 674 & 8 & 1.2 \\
\hline & 4714 & 352 & 0 & 0.0 \\
\hline & 4715 & 371 & 16 & 4.3 \\
\hline Bolton (0.4) & 5291 & 258 & 1 & 0.4 \\
\hline \multirow[t]{2}{*}{ Canton (2.6) } & 4641.01 & 147 & 3 & 2.0 \\
\hline & 4641.02 & 579 & 16 & 2.8 \\
\hline East Granby (0.0) & 4701 & 344 & 0 & 0.0 \\
\hline \multirow{14}{*}{ East Hartford (7.0) } & 5101 & 352 & 27 & 7.7 \\
\hline & 5102 & 673 & 25 & 3.7 \\
\hline & 5103 & 953 & 49 & 5.1 \\
\hline & 5104 & 1754 & 102 & 5.8 \\
\hline & 5105 & 942 & 49 & 5.2 \\
\hline & 5106 & 1420 & 51 & 3.6 \\
\hline & 5107 & 581 & 28 & 4.8 \\
\hline & 5108 & 546 & 39 & 7.1 \\
\hline & 5109 & 52 & 3 & 5.8 \\
\hline & 5110 & 47 & 0 & 0.0 \\
\hline & 5111 & 71 & 4 & 5.6 \\
\hline & 5112 & 558 & 71 & 12.7 \\
\hline & 5113 & 773 & 35 & 4.5 \\
\hline & 5114 & 38 & 7 & 18.4 \\
\hline \multirow[t]{2}{*}{ East Windsor (1.0) } & 4841 & 792 & 9 & 1.1 \\
\hline & 4842 & 791 & 7 & 0.9 \\
\hline \multirow[t]{2}{*}{ Ellington (0.4) } & 5351 & 1161 & 3 & 0.3 \\
\hline & 5352 & 206 & 2 & 1.0 \\
\hline \multirow[t]{12}{*}{ Enfield (4.8) } & 4802 & 170 & 1 & 0.6 \\
\hline & 4803 & 129 & 5 & 3.9 \\
\hline & 4804 & 133 & 5 & 3.8 \\
\hline & 4805 & 280 & 8 & 2.9 \\
\hline & 4806 & 1595 & 131 & 8.2 \\
\hline & 4807 & 331 & 0 & 0.0 \\
\hline & 4808 & 504 & 13 & 2.6 \\
\hline & 4809 & 104 & 3 & 2.9 \\
\hline & 4810 & 47 & 1 & 2.1 \\
\hline & 4811 & 195 & 10 & 5.1 \\
\hline & 4812 & 508 & 1 & 0.2 \\
\hline & 4813 & 92 & 7 & 7.6 \\
\hline
\end{tabular}




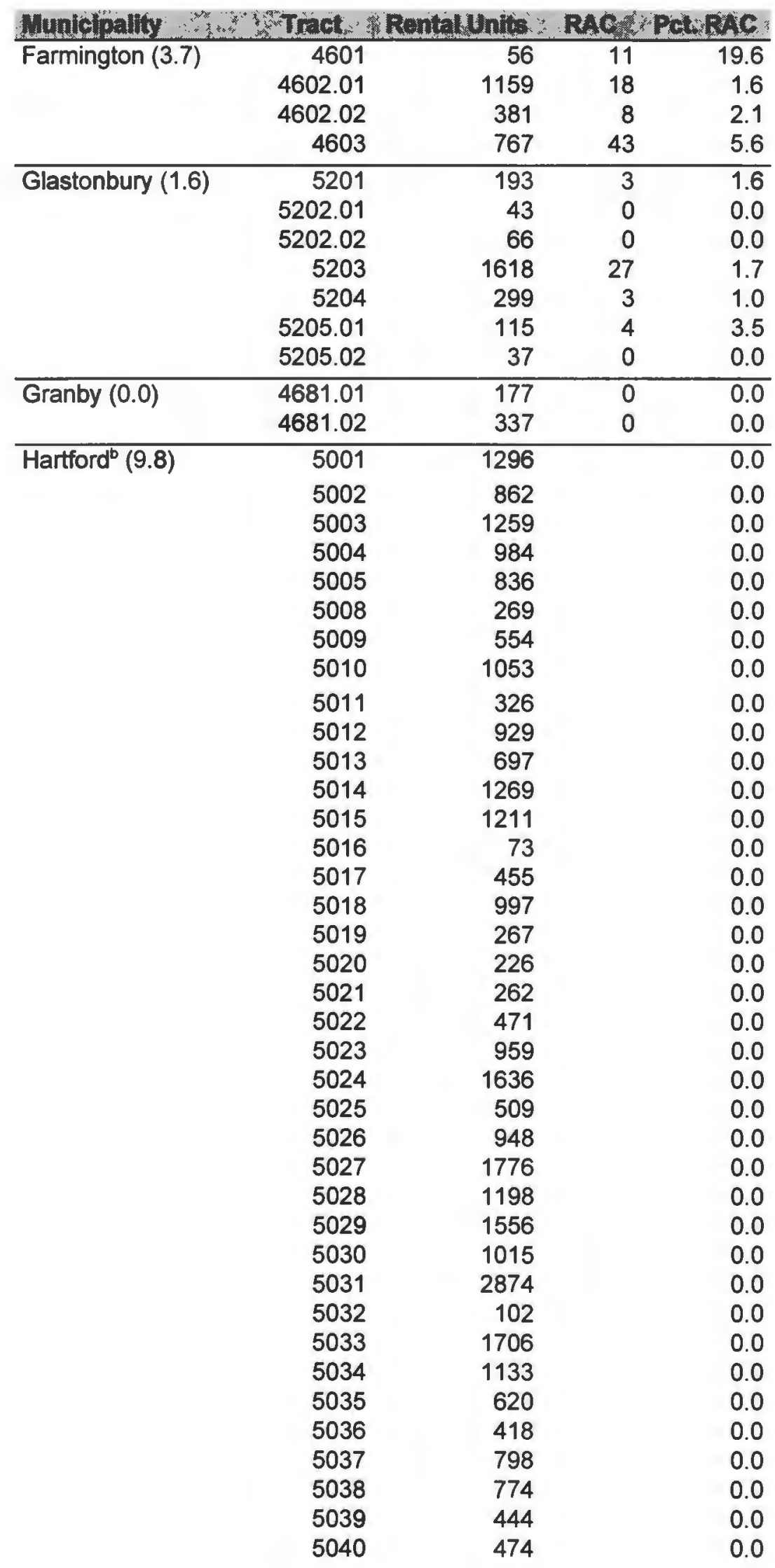




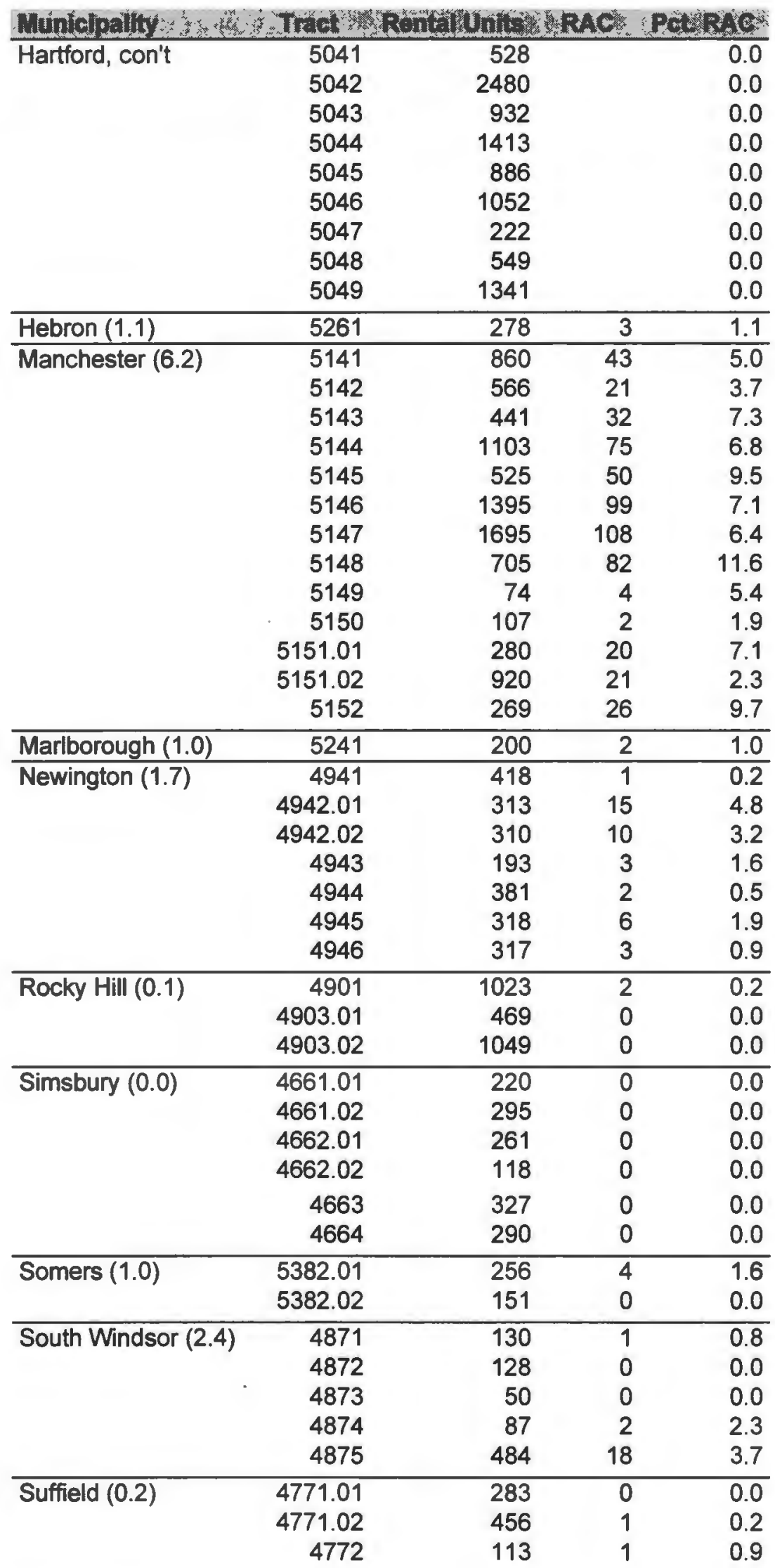




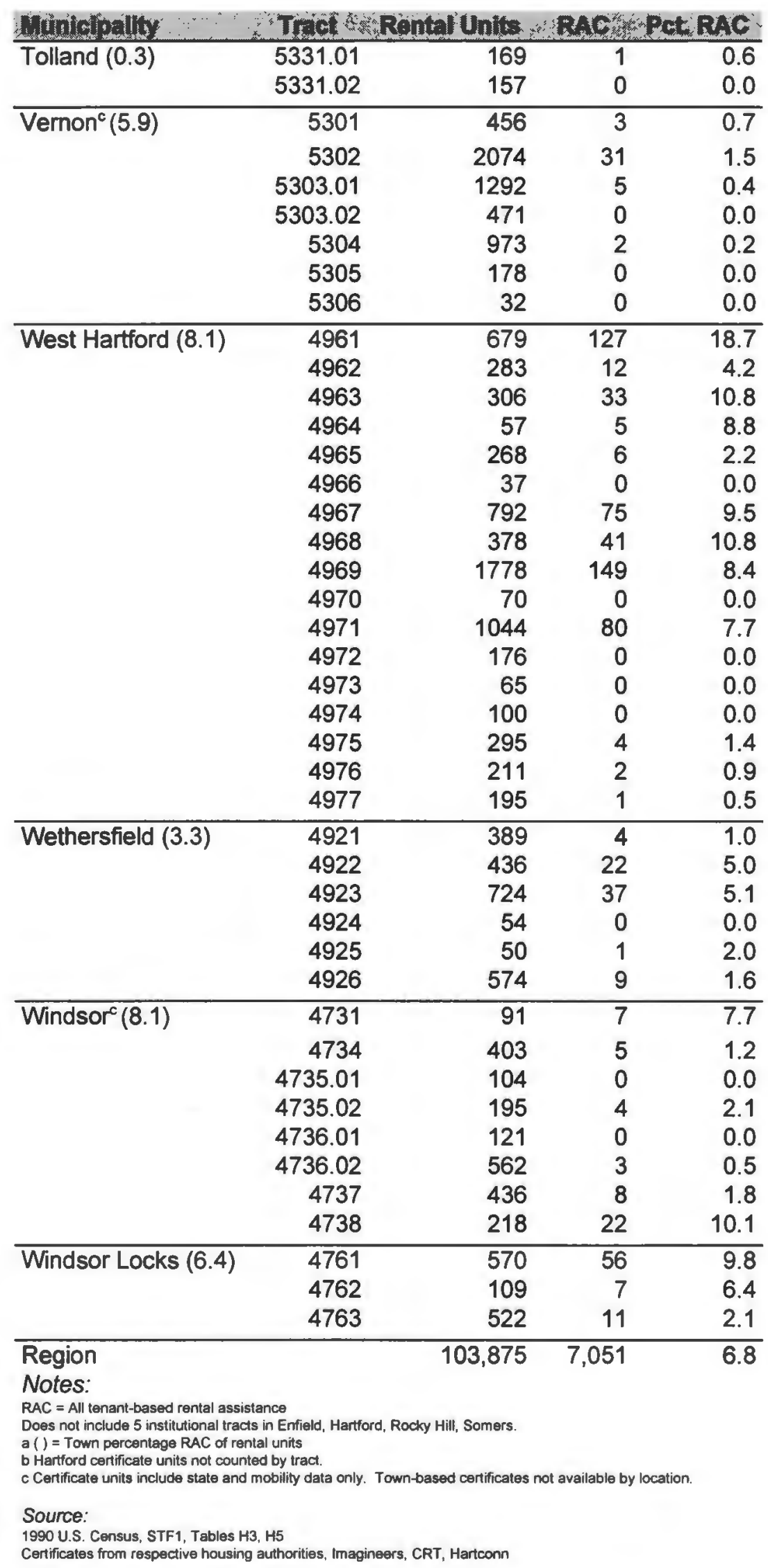




\section{APPENDIX 5}

\section{Capitol Region Minority Households} By Town and Tract, 1990

\begin{tabular}{lrr} 
Municipality & Tract & Pct. Minority \\
\hline Andover (1.7) & 5281 & 1.7 \\
\hline Avon (3.4) & 4621.01 & 3.1 \\
& 4621.02 & 3.2 \\
& 4622.01 & 3.2 \\
& 4622.02 & 4.9 \\
\hline Bloomfield (45.7) & 4711 & 76.5 \\
& 4712 & 66.3 \\
& 4713 & 33.5 \\
& 4714 & 16.7 \\
Bolton (3.1) & 4715 & 49.4 \\
\hline Canton (2.5) & 5291 & 3.1 \\
\hline East Granby (3.1) & 4641.01 & 2.3 \\
\hline East Hartford (16.6) & 4641.02 & 2.6 \\
\hline & 4701 & 3.1 \\
\hline & 5101 & 8.6 \\
& 5102 & 16.9 \\
& 5103 & 29.4 \\
& 5104 & 25.5 \\
& 5105 & 27.7 \\
& 5106 & 25.5 \\
& 4107 & 13.0 \\
& 4813 & 16.2 \\
& & 6.3 \\
& 48108 & 2.3
\end{tabular}




\begin{tabular}{|c|c|c|}
\hline 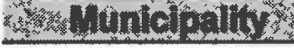 & SIst & ithy \\
\hline Farmington (4.7) & 4601 & 4.4 \\
\hline & 4602.01 & 5.2 \\
\hline & 4602.02 & 5.3 \\
\hline & 4603 & 4.1 \\
\hline Glastonbury (5.4) & 5201 & 6.4 \\
\hline & 5202.01 & 3.9 \\
\hline & 5202.02 & 3.5 \\
\hline & 5203 & 8.9 \\
\hline & 5204 & 3.1 \\
\hline & 5205.01 & 3.3 \\
\hline & 5205.02 & 3.3 \\
\hline Granby (2.3) & 4681.01 & 2.3 \\
\hline & 4681.02 & 2.2 \\
\hline$\overline{\text { Hartford (69.5) }}$ & 5001 & 67.1 \\
\hline & 5002 & 71.5 \\
\hline & 5003 & 81.5 \\
\hline & 5004 & 89.2 \\
\hline & 5005 & 57.6 \\
\hline & 5008 & 99.8 \\
\hline & 5009 & 99.6 \\
\hline & 5010 & 99.1 \\
\hline & 5011 & 95.7 \\
\hline & 5012 & 99.6 \\
\hline & 5013 & 98.7 \\
\hline & 5014 & 99.4 \\
\hline & 5015 & 98.3 \\
\hline & 5016 & 95.1 \\
\hline & 5017 & 98.9 \\
\hline & 5018 & 98.9 \\
\hline & 5019 & 72.1 \\
\hline & 5020 & 50.3 \\
\hline & 5021 & 28.4 \\
\hline & 5022 & 65.7 \\
\hline & 5023 & 11.2 \\
\hline & 5024 & 27.7 \\
\hline & 5025 & 33.3 \\
\hline & 5026 & 19.8 \\
\hline & 5027 & 48.2 \\
\hline & 5028 & 88.4 \\
\hline & 5029 & 80.6 \\
\hline & 5030 & 76.0 \\
\hline & 5031 & 62.5 \\
\hline & 5032 & 51.8 \\
\hline & 5033 & 87.6 \\
\hline & 5034 & 89.9 \\
\hline & 5035 & 99.1 \\
\hline & 5036 & 50.5 \\
\hline & 5037 & 97.0 \\
\hline & 5038 & 49.0 \\
\hline & 5039 & 96.0 \\
\hline & 5040 & 94.3 \\
\hline
\end{tabular}




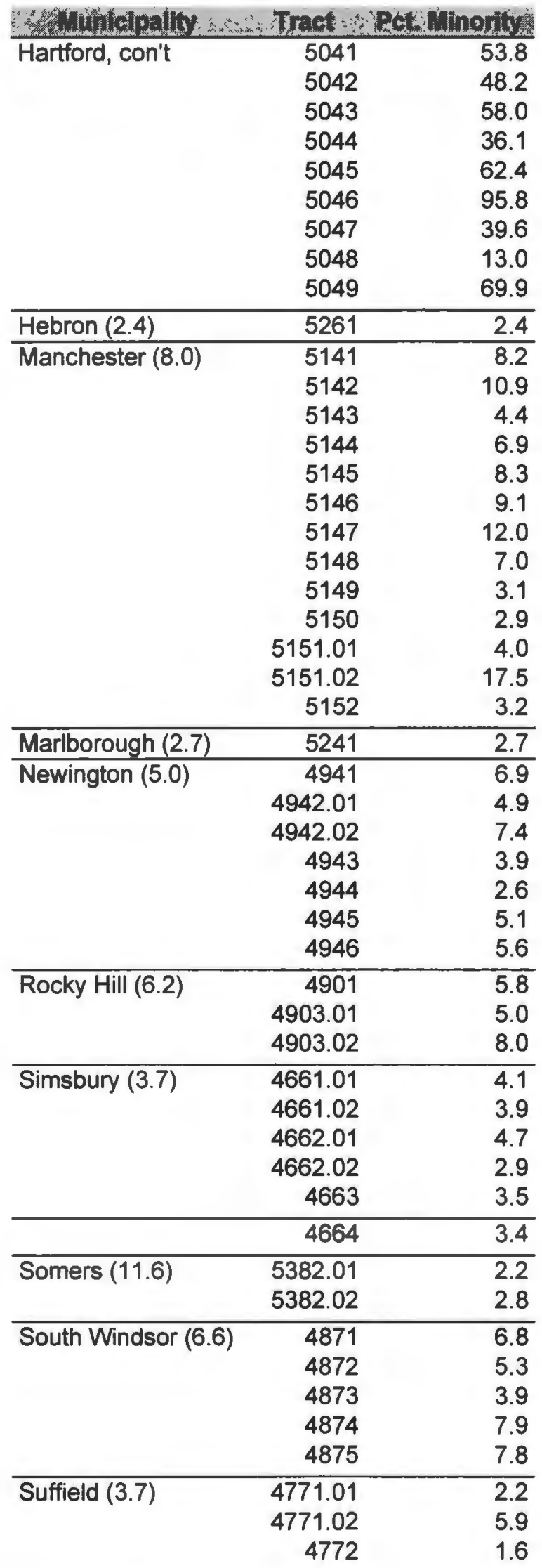




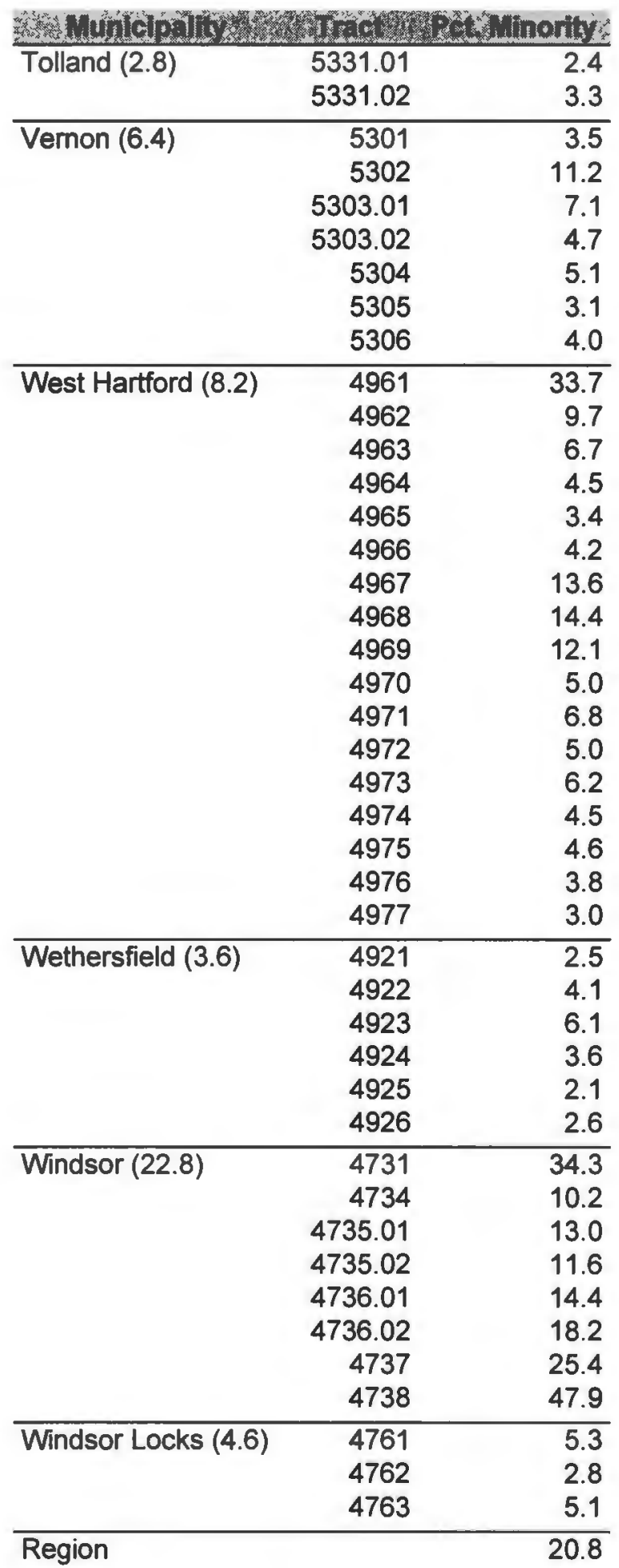

Notes:

Does not include 5 institutional tracts in Enfield, Hartford, Rocky Hill, and Somers.

() = Town percentage of minority households

Source:

1990 U.S. Census, STF1, Table P1 


\section{APPENDIX 6}

\section{Capitol Region Low Income Households}

By Town and Tract, 1990

\begin{tabular}{|c|c|c|c|}
\hline Municipality & Tract & $\begin{array}{l}\text { Pct. of HHs at } \\
50 \text { pct. of town } \\
\text { med. income }\end{array}$ & $\begin{array}{l}\text { Pct. of HHs at } \\
80 \text { pct. of town } \\
\text { med. income }\end{array}$ \\
\hline Andover $(17.8,30.6)$ & 5281 & 17.8 & 30.6 \\
\hline \multirow[t]{4}{*}{ Avon $(19.4,38.4)$} & 4621.01 & 16.1 & 34.2 \\
\hline & 4621.02 & 16.8 & 36.2 \\
\hline & 4622.01 & 24.3 & 44.4 \\
\hline & 4622.02 & 20.4 & 38.7 \\
\hline \multirow[t]{5}{*}{ Bloomfield $(21.9,36.7)$} & 4711 & 17.0 & 36.5 \\
\hline & 4712 & 22.6 & 40.9 \\
\hline & 4713 & 27.6 & 42.2 \\
\hline & 4714 & 16.4 & 27.0 \\
\hline & 4715 & 28.4 & 42.8 \\
\hline Bolton $(16.9,37.9)$ & 5291 & 16.9 & 37.9 \\
\hline \multirow[t]{2}{*}{ Canton $(19.4,38.4)$} & 4641.01 & 17.2 & 22.9 \\
\hline & 4641.02 & 29.5 & 44.9 \\
\hline East Granby $(17.2,36.4)$ & 4701 & 17.2 & 36.4 \\
\hline \multirow[t]{14}{*}{ East Hartford $(20.2,37.2)$} & 5101 & 26.6 & 35.8 \\
\hline & 5102 & 30.3 & 45.7 \\
\hline & 5103 & 18.8 & 39.5 \\
\hline & 5104 & 27.4 & 51.5 \\
\hline & 5105 & 11.0 & 32.4 \\
\hline & 5106 & 35.4 & 55.4 \\
\hline & 5107 & 22.7 & 37.3 \\
\hline & 5108 & 23.3 & 43.5 \\
\hline & 5109 & 7.5 & 17.3 \\
\hline & 5110 & 11.1 & 22.6 \\
\hline & 5111 & 5.9 & 18.1 \\
\hline & 5112 & 21.4 & 37.2 \\
\hline & 5113 & 19.6 & 41.0 \\
\hline & 5114 & 10.0 & 20.3 \\
\hline \multirow[t]{2}{*}{ East Windsor $(17.4,37.8)$} & 4841 & 16.9 & 34.5 \\
\hline & 4842 & 17.9 & 40.5 \\
\hline \multirow[t]{2}{*}{ Ellington $(15.4,34.4)$} & 5351 & 14.0 & 32.8 \\
\hline & 5352 & 17.7 & 37.2 \\
\hline \multirow[t]{12}{*}{ Enfield $(19.0,35.7)$} & 4802 & 10.5 & 25.1 \\
\hline & 4803 & 15.2 & 37.6 \\
\hline & 4804 & 12.4 & 28.6 \\
\hline & 4805 & 31.8 & 52.3 \\
\hline & 4806 & 39.2 & 61.6 \\
\hline & 4807 & 36.1 & 53.7 \\
\hline & 4808 & 20.0 & 40.1 \\
\hline & 4809 & 14.4 & 29.2 \\
\hline & 4810 & 6.7 & 15.2 \\
\hline & 4811 & 13.2 & 27.8 \\
\hline & 4812 & 10.0 & 24.8 \\
\hline & 4813 & 14.3 & 26.3 \\
\hline Farmington $(19.3,37.0)$ & 4601 & 14.6 & 28.8 \\
\hline
\end{tabular}




\begin{tabular}{|c|c|c|c|}
\hline Municipality & Tract & $\begin{array}{l}\text { Pct. of HHs at } \\
50 \text { pet. of town } \\
\text { med. income }\end{array}$ & $\begin{array}{l}\text { Pct. of HHs at } \\
80 \text { pct. of town } \\
\text { med. income }\end{array}$ \\
\hline \multirow[t]{3}{*}{ Farmington, con't. } & 4602.01 & 22.8 & 40.0 \\
\hline & 4602.02 & 13.4 & 29.2 \\
\hline & 4603 & 19.7 & 39.7 \\
\hline \multirow[t]{7}{*}{ Glastonbury $(19.4,37.5)$} & 5201 & 10.9 & 29.0 \\
\hline & 5202.01 & 11.7 & 26.0 \\
\hline & 5202.02 & 16.3 & 24.0 \\
\hline & 5203 & 29.1 & 56.7 \\
\hline & 5204 & 19.1 & 30.8 \\
\hline & 5205.01 & 13.4 & 26.1 \\
\hline & 5205.02 & 15.2 & 33.0 \\
\hline \multirow{2}{*}{ Granby $(15.4,35.1)$} & 4681.01 & 13.5 & 35.0 \\
\hline & 4681.02 & 18.6 & 35.4 \\
\hline \multirow[t]{38}{*}{ Hartford $(29.4,45.5)$} & 5001 & 27.0 & 44.5 \\
\hline & 5002 & 29.0 & 48.7 \\
\hline & 5003 & 37.4 & 51.2 \\
\hline & 5004 & 44.0 & 60.4 \\
\hline & 5005 & 45.7 & 60.3 \\
\hline & 5008 & 44.8 & 78.6 \\
\hline & 5009 & 63.2 & 77.6 \\
\hline & 5010 & 70.3 & 83.7 \\
\hline & 5011 & 47.7 & 61.2 \\
\hline & 5012 & 39.1 & 55.7 \\
\hline & 5013 & 54.9 & 70.2 \\
\hline & 5014 & 46.4 & 62.5 \\
\hline & 5015 & 31.9 & 47.5 \\
\hline & 5016 & 44.2 & 67.2 \\
\hline & 5017 & 32.9 & 51.1 \\
\hline & 5018 & 51.1 & 65.5 \\
\hline & 5019 & 58.0 & 64.7 \\
\hline & 5020 & 22.1 & 36.6 \\
\hline & 5021 & 8.8 & 16.2 \\
\hline & 5022 & 24.2 & 43.5 \\
\hline & 5023 & 10.8 & 23.3 \\
\hline & 5024 & 19.6 & 30.5 \\
\hline & 5025 & 12.3 & 21.6 \\
\hline & 5026 & 13.1 & 25.3 \\
\hline & 5027 & 32.6 & 50.7 \\
\hline & 5028 & 49.4 & 65.5 \\
\hline & 5029 & 41.2 & 56.2 \\
\hline & 5030 & 42.5 & 55.7 \\
\hline & 5031 & 28.7 & 52.9 \\
\hline & 5032 & 46.9 & 68.4 \\
\hline & 5033 & 29.5 & 54.0 \\
\hline & 5034 & 28.5 & 47.5 \\
\hline & 5035 & 35.4 & 46.6 \\
\hline & 5036 & 34.6 & 42.7 \\
\hline & 5037 & 22.2 & 37.2 \\
\hline & 5038 & 24.0 & 59.0 \\
\hline & 5039 & 8.9 & 18.2 \\
\hline & 5040 & 8.2 & 19.1 \\
\hline
\end{tabular}




\begin{tabular}{|c|c|c|c|}
\hline Municipality & Tract & $\begin{array}{l}\text { Pet. of HHs at } \\
50 \text { pet. of torm } \\
\text { med. income }\end{array}$ & $\begin{array}{l}\text { Pot of HHs at } \\
80 \text { pct of town } \\
\text { med. income }\end{array}$ \\
\hline \multirow[t]{9}{*}{ Hartford, con't } & 5041 & 23.9 & 39.0 \\
\hline & 5042 & 26.3 & 40.3 \\
\hline & 5043 & 31.1 & 51.6 \\
\hline & 5044 & 12.9 & 28.5 \\
\hline & 5045 & 17.2 & 32.4 \\
\hline & 5046 & 52.3 & 71.2 \\
\hline & 5047 & 13.3 & 26.1 \\
\hline & 5048 & 8.8 & 22.3 \\
\hline & 5049 & 21.7 & 40.4 \\
\hline Hebron $(16.5,34.9)$ & 5261 & 16.5 & 34.9 \\
\hline \multirow[t]{13}{*}{ Manchester $(18.4,38.3)$} & 5141 & 10.9 & 32.0 \\
\hline & 5142 & 24.5 & 47.0 \\
\hline & 5143 & 18.9 & 38.0 \\
\hline & 5144 & 19.3 & 41.4 \\
\hline & 5145 & 13.4 & 32.4 \\
\hline & 5146 & 29.2 & 50.8 \\
\hline & 5147 & 28.0 & 54.2 \\
\hline & 5148 & 20.9 & 41.8 \\
\hline & 5149 & 14.7 & 31.7 \\
\hline & 5150 & 11.4 & 28.6 \\
\hline & 5151.01 & 14.2 & 39.5 \\
\hline & 5151.02 & 16.1 & 30.2 \\
\hline & 5152 & 9.8 & 18.5 \\
\hline Marlborough $(14.5,34.9)$ & 5241 & 14.5 & 34.9 \\
\hline \multirow[t]{7}{*}{ Newington $(18.8,37.8)$} & 4941 & 13.4 & 34.8 \\
\hline & 4942.01 & 17.7 & 36.8 \\
\hline & 4942.02 & 11.0 & 26.6 \\
\hline & 4943 & 18.0 & 38.1 \\
\hline & 4944 & 26.0 & 41.0 \\
\hline & 4945 & 19.6 & 40.0 \\
\hline & 4946 & 22.7 & 42.4 \\
\hline \multirow[t]{3}{*}{ Rocky Hill $(16.3,37.8)$} & 4901 & 22.2 & 45.1 \\
\hline & 4903.01 & 15.1 & 34.9 \\
\hline & 4903.02 & 10.1 & 31.9 \\
\hline \multirow[t]{6}{*}{ Simsbury $(17.3,35.9)$} & 4661.01 & 17.4 & 39.6 \\
\hline & 4661.02 & 12.1 & 32.2 \\
\hline & 4662.01 & 22.5 & 37.1 \\
\hline & 4662.02 & 9.4 & 23.2 \\
\hline & 4663 & 19.3 & 40.9 \\
\hline & 4664 & 31.9 & 48.1 \\
\hline \multirow[t]{2}{*}{ Somers $(19.7,36.3)$} & 5382.01 & 18.6 & 42.1 \\
\hline & 5382.02 & 21.0 & 37.6 \\
\hline \multirow[t]{5}{*}{ South Windsor $(13.3,34.8)$} & 4871 & 11.5 & 31.4 \\
\hline & 4872 & 12.0 & 29.8 \\
\hline & 4873 & 11.0 & 26.5 \\
\hline & 4874 & 15.6 & 38.9 \\
\hline & 4875 & 15.8 & 42.1 \\
\hline \multirow[t]{3}{*}{ Suffield $(17.7,37.1)$} & 4771.01 & 17.1 & 39.8 \\
\hline & 4771.02 & 19.9 & 36.7 \\
\hline & 4772 & 14.3 & 34.4 \\
\hline
\end{tabular}




\begin{tabular}{|c|c|c|c|}
\hline & Tract & $\begin{array}{l}\text { Pct of HHs at } \\
50 \text { pct. of town } \\
\text { med. income }\end{array}$ & $\begin{array}{l}\text { Pct. of HHs at } \\
80 \text { pct. of town } \\
\text { med. Income }\end{array}$ \\
\hline \multirow[t]{2}{*}{ Tolland $(12.1,33.5)$} & 5331.01 & 13.5 & 34.6 \\
\hline & 5331.02 & 10.4 & 32.0 \\
\hline \multirow[t]{7}{*}{ Vernon $(21.0,38.1)$} & 5301 & 27.1 & 50.2 \\
\hline & 5302 & 32.7 & 51.6 \\
\hline & 5303.01 & 16.7 & 34.5 \\
\hline & 5303.02 & 15.3 & 28.0 \\
\hline & 5304 & 20.8 & 46.3 \\
\hline & 5305 & 19.5 & 29.3 \\
\hline & 5306 & 5.2 & 12.3 \\
\hline \multirow[t]{17}{*}{ West Hartford $(21.3,36.6)$} & 4961 & 38.9 & 65.5 \\
\hline & 4962 & 26.9 & 48.5 \\
\hline & 4963 & 21.9 & 43.0 \\
\hline & 4964 & 16.9 & 28.7 \\
\hline & 4965 & 18.0 & 29.8 \\
\hline & 4966 & 11.6 & 26.5 \\
\hline & 4967 & 26.7 & 49.3 \\
\hline & 4968 & 31.2 & 54.6 \\
\hline & 4969 & 30.0 & 52.7 \\
\hline & 4970 & 9.8 & 21.7 \\
\hline & 4971 & 22.7 & 50.0 \\
\hline & 4972 & 11.8 & 29.1 \\
\hline & 4973 & 12.1 & 29.4 \\
\hline & 4974 & 11.9 & 23.3 \\
\hline & 4975 & 25.6 & 37.5 \\
\hline & 4976 & 20.3 & 40.3 \\
\hline & 4977 & 11.6 & 17.6 \\
\hline \multirow{6}{*}{ Wethersfield $(21.5,39.9)$} & 4921 & 20.2 & 40.4 \\
\hline & 4922 & 25.9 & 44.7 \\
\hline & 4923 & 22.4 & 45.6 \\
\hline & 4924 & 17.6 & 37.0 \\
\hline & 4925 & 13.3 & 29.3 \\
\hline & 4926 & 24.0 & 37.6 \\
\hline \multirow[t]{8}{*}{ Windsor $(14.2,29.4)$} & 4731 & 10.6 & 23.8 \\
\hline & 4734 & 30.7 & 50.9 \\
\hline & 4735.01 & 6.3 & 14.5 \\
\hline & 4735.02 & 10.7 & 22.1 \\
\hline & 4736.01 & 6.1 & 16.9 \\
\hline & 4736.02 & 10.5 & 32.9 \\
\hline & 4737 & 20.3 & 39.5 \\
\hline & 4738 & 23.7 & 43.3 \\
\hline \multirow[t]{3}{*}{ Windsor Locks $(22.7,43.8)$} & 4761 & 34.7 & 55.0 \\
\hline & 4762 & 17.7 & 36.3 \\
\hline & 4763 & 16.7 & 39.6 \\
\hline Region & & 20.9 & 38.4 \\
\hline
\end{tabular}

() = Percentage of town households at 50 and 80 percent of median income

Does not include 5 institutional tracts in Enfield, Hartford, Rocky Hill, and Somers

Source:

1990 U.S. Census, STF3, Table P8 


\section{WORKS CITED}

Blau, Francine and Marianne A. Ferber. 1986. The economics of women, men, and work. Englewood Cliffs, NJ: Prentice-Hall.

Bergmann, Barbara R. 1986. The economic emergence of women. New York: Basic Books.

Capitol Region Council of Governments. July 1995. Data profile of the Capitol Region. Hartford, CT: CRCOG.

Capitol Region Council of Governments. September 1995. Capitol Region Fair Housing Compact: Annual report. Hartford, CT: CRCOG.

Connecticut Department of Housing. 1994. Report to the General Assembly: $D O H$ tenant demographics report. Hartford, CT: CT Department of Housing.

Connecticut Public Act 88-334, 1988.

CRCOG Housing Committee. 1995. Recommendation regarding future of Capitol Region Fair Housing Compact on affordable housing. Hartford, CT: Capitol Region Council of Governments. November 6.

CRCOG. July 1995. see Capitol Region Council of Governments. July 1995.

CRCOG. September 1995. see Capitol Region Council of Governments. September 1995.

Donovan, Shaun. 1993. Moving to the suburbs: Section 8 mobility and portability in Hartford. Paper submitted to Professor Gary Orfield, Harvard University, Cambridge, MA. May 7.

Dewitt, Karen. 1995. Housing voucher test in Maryland is scuttled by a political firestorm. The New York Times, 28, March, A14.

Fischer, Paul B. 1991. Is housing mobility and effective anti-poverty strategy? An examination of the Cincinnati Experience. Cincinnati, $\mathrm{OH}$ : The Stephen $\mathrm{H}$. Wilder Foundation.

French, Marilyn. 1992. The war against women. New York: Summit Books. 
Galster, George and Edward Hill, eds. 1992. Metropolis in black and white. New Brunswick, NJ: Center for Urban Policy Research.

Harris, Carl. 1996. Equal Opportunity Specialist in the Connecticut State Office of HUD. Phone interview conducted by author.

Henderson, Hazel. 1991. Paradigms in progress: Life beyond economics. San Francisco: Koehler Publishers.

hooks, bell. 1984. feminist theory: from margin to center. Boston: South End Press.

Kasarda, John P. 1993. Inner city concentrated poverty and neighborhood distress: 1970 to 1990. Housing Policy Debate. 4 no. 3: 255-302.

Kowalewski, Mary Ellen. 1996. Director of Community Development, CRCOG. Phone interview conducted by author.

Land, Kenneth C. and Seymour Spilerman, eds. 1975. Social indicator models. New York: Russell Sage Foundation.

Massachusetts State Data Center, Mass. Institute for Social and Economic Research. Amherst, MA: University of Massachusetts State Data Center.

Mulroy, Elizabeth A., ed. 1988. Women as single parents; Confronting institutional barriers in the courts, the workplace, and the housing market. Westport, CT: Greenwood.

Polikoff, Alexander, ed. 1995. Housing mobility: Promise or illusion. Washington D.C.: The Urban Institute.

Rosenbaum, James E. and Susan J. Popkin. 1991. The Gautreaux program: An experiment in racial and economic integration. Northwestern University, Center for Urban Affairs and Policy Research.

Rossi, Robert and Kevin Gilmartin. 1980. The handbook of social indicators. New York: Garland Press.

Sidel, Ruth. 1986. Women and children last. New York: Penquin Press.

Smith, Barbara, ed. 1983. Home girls: A black feminist anthology. New York: Kitchen Table: Women of Color Press.

Stack, Carol B. 1974. All our kin: strategies for survival in a black community. New York: Harper \& Row. 
Susskind, Lawrence E. and Susan L. Podziba. 1990. Affordable housing mediation: Building consensus for regional agreements in the Hartford and Greater Bridgeport areas. Cambridge, MA: Lincoln Institute of Land Policy.

Swift, Mike and Christine Dempsey. 1995. City plan worries East Hartford mayor. Hartford Courant, 15 July, A3 and A6.

U.S. Bureau of the Census. 1995. Statistical Abstract of the United States 1995, 115 ed. Washington D.C. September

U.S. Department of Housing and Urban Development. 1995. Regionalism: The new geography of opportunity. Washington D.C.: U.S. Department of Housing and Urban Development. March.

U.S. Department of Housing and Urban Development. March 1994. Office of Policy Development and Research. Regional housing opportunities for lower income households: A resource guide to affordable housing and regional mobility strategies, by Robert W. Burchell, David Listokin, and Arlene Pashmen. Rutgers University Center for Urban Policy Research.

U.S. Department of Housing and Urban Development. October 1994. Office of Policy Development and Research. Section 8 rental voucher and rental certificate utilization study: Final Report, by Stephen D. Kennedy and Meryl Finkel. Abt Associates.

U.S. Department of Housing and Urban Development. 1991. Portability of Section 8 certificates and housing voucher within the same state, or the same or a contiguous metropolitan statistical area. HUD Notice 91-19. Issued March 4. 